Prepared in cooperation with the Platte River Recovery Implementation Program

\title{
Foraging Ecology of Least Terns and Piping Plovers Nesting on Central Platte River Sandpits and Sandbars
}

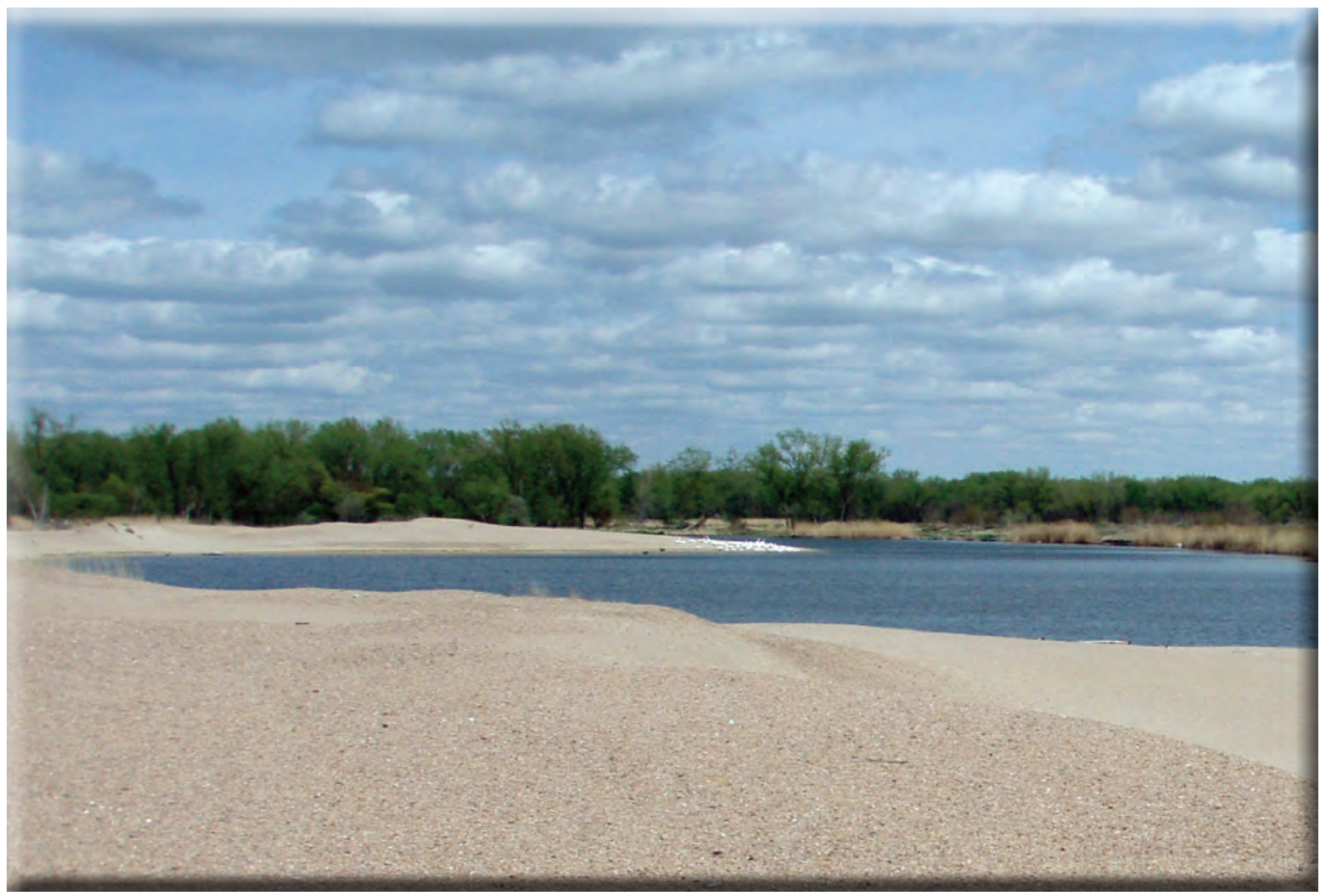

Open-File Report 2012-1059 
Cover photograph. Least tern and piping plover nesting habitat on Central Platte River sandpit, May 11, 2009.

Photograph by Mark H. Sherfy, U.S. Geological Survey. 


\section{Foraging Ecology of Least Terns and Piping Plovers Nesting on Central Platte River Sandpits and Sandbars}

By Mark H. Sherfy, Michael J. Anteau, Terry L. Shaffer, Marsha A. Sovada, and Jennifer H. Stucker

Prepared in cooperation with the Platte River Recovery Implementation Program

Open-File Report 2012-1059 


\section{U.S. Department of the Interior KEN SALAZAR, Secretary}

\section{U.S. Geological Survey Marcia K. McNutt, Director}

\section{U.S. Geological Survey, Reston, Virginia: 2012}

For more information on the USGS - the Federal source for science about the Earth, its natural and living resources, natural hazards, and the environment, visit http://www.usgs.gov or call 1-888-ASK-USGS.

For an overview of USGS information products, including maps, imagery, and publications, visit http://www.usgs.gov/pubprod

Any use of trade, product, or firm names is for descriptive purposes only and does not imply endorsement by the U.S. Government.

Although this report is in the public domain, permission must be secured from the individual copyright owners to reproduce any copyrighted materials contained within this report.

Suggested citation:

Sherfy, M.H., Anteau, M.J., Shaffer, T.L., Sovada, M.A., and Stucker, J.H., 2012, Foraging ecology of least terns and piping plovers nesting on Central Platte River sandpits and sandbars: U.S. Geological Survey Open-File Report 2012-1059, 50 p. 


\section{Acknowledgments}

We thank the Platte River Recovery Implementation Program for funding and logistical support of this study. Chad Smith, Jim Jenniges, Mark Czaplewski, Mark Peyton, Mike Fritz, Martha Tacha, and Justin Brei provided valuable insights, advice, and guidance on conducting research on the Platte River system. We appreciate the cooperation of Mary Bomberger Brown and Joel Jorgenson from the Tern and Plover Conservation Partnership with ensuring the use of unique color band combinations.

Our crew, including crew leaders John Campbell, Nate Emery, and Megan Ring and technicians Nick Altadonna, Kasey Clark, Justin Edwards, Anna Fasoli, Elizabeth Hanson, Megan Ring, Jhanine Rivera, Gabrielle Robinson, Jessi Tapp, Jason Tappa, and Jennifer Williams, worked many long hours and provided valuable insights into tern and plover ecology on the Platte River. We appreciate their dedication and hard work on collecting many diverse types of ecological data. Finally, we appreciate the leadership, oversight, and quality control provided by Colin Dovichin, Megan Ring, and Mark Wiltermuth

\section{Contents}

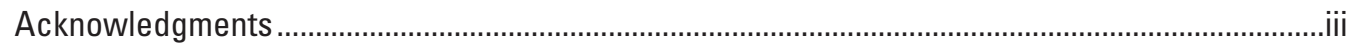

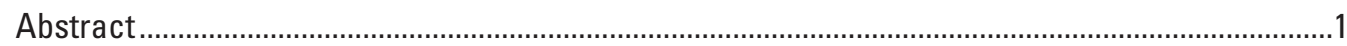

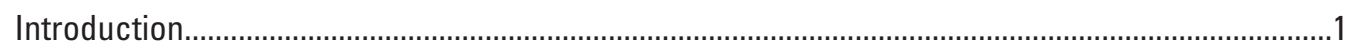

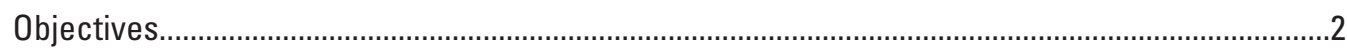

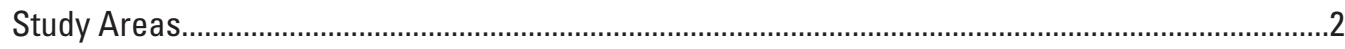

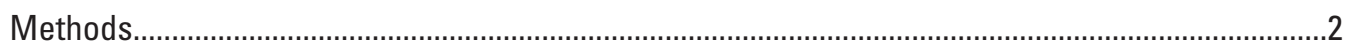

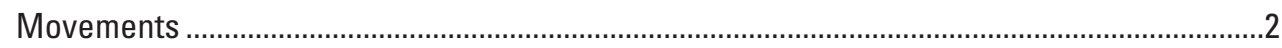

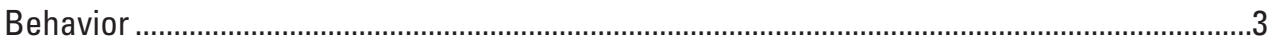

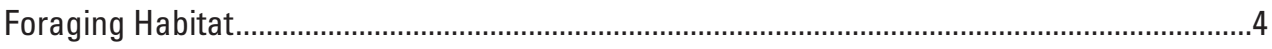

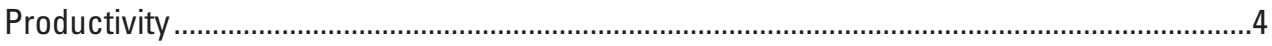

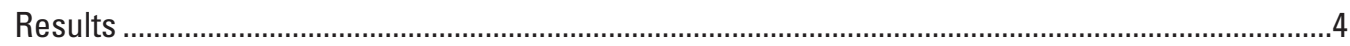

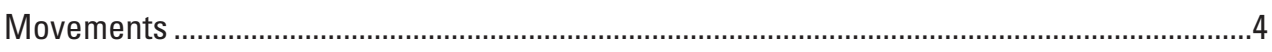

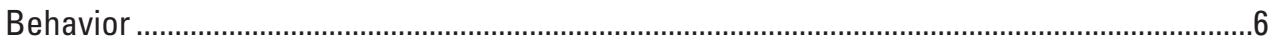

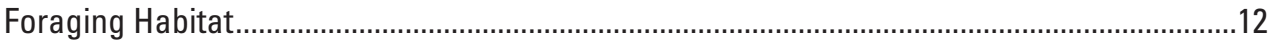

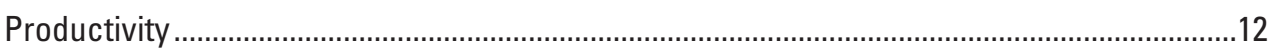

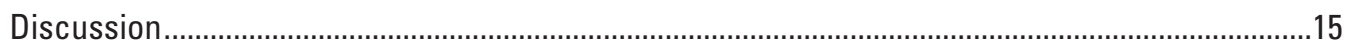

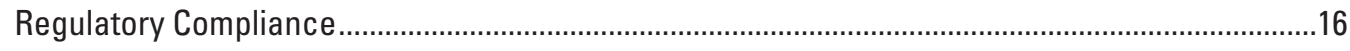

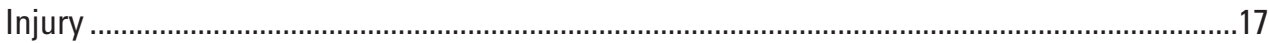

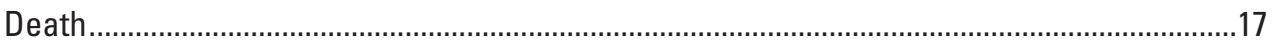

Human Disturbance ........................................................................................................ 17

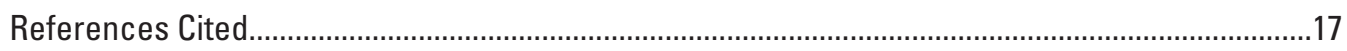

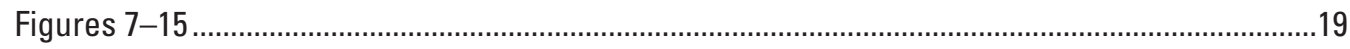

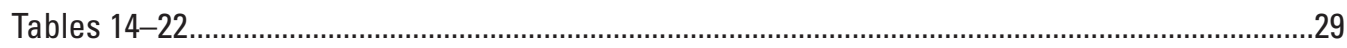




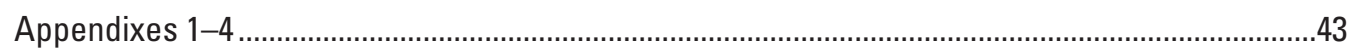

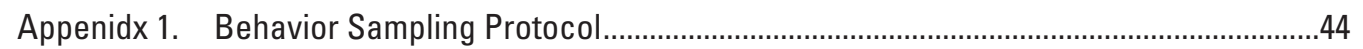

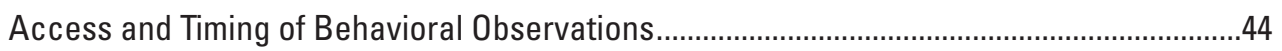

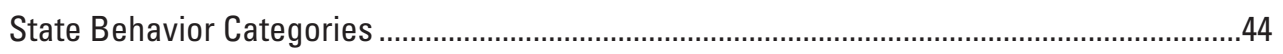

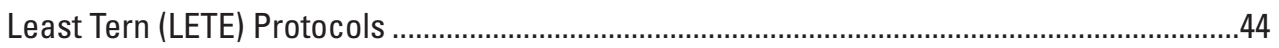

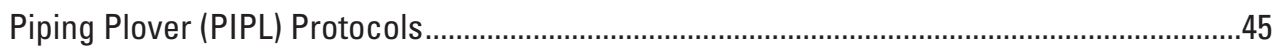

Habitat Classes (dominant classes within the foraging area) ...................................................46

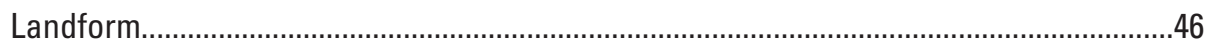

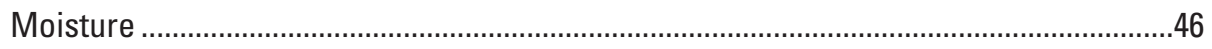

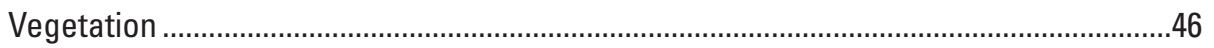

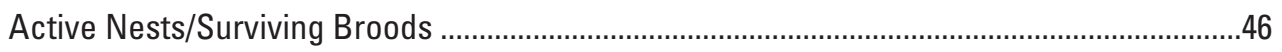

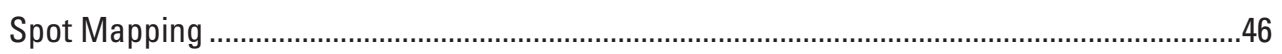

Appendix 2. Terrestrial Habitat Sampling Protocol.....................................................................

Appendix 3. Fish Sampling Protocol....................................................................................

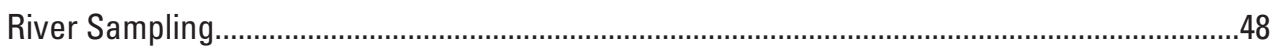

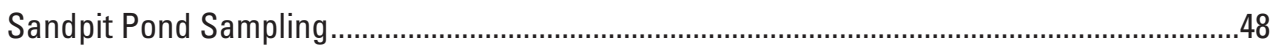

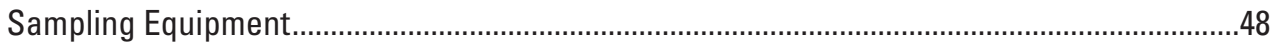

Appendix 4. Invertebrate Sampling Protocol.............................................................................49

\section{Figures}

1. Map showing locations of dataloggers used to monitor presence of radio-marked least terns and piping plovers on the Central Platte River during 2010.

2. Graph showing distribution of movement events across hours of the day for radio-marked piping plovers on the Central Platte River, 2009-10.

4. Graph showing distribution of movement events across hours of the day for radio-marked least terns during four stages of the reproductive cycle on the Central Platte River, 2009-10.

3. Graph showing distribution of movement events across hours of the day for radio-marked least terns on the Central Platte River, 2009-10

5. Graph showing mean maximum distance (plus or minus 95-percent confidence interval) moved by radio-marked least terns across hours of the day on the Central Platte River, 2009-10.

6. Graph showing mean maximum distance moved by radio-marked least terns across hours of the day during four stages of the reproductive cycle on the Central Platte River, 2009-10.

7. Map showing spot-mapped locations of foraging least terns and piping plovers from 2009-10 at Dippel Tract, near Gibbon, Nebraska

8. Map showing spot-mapped locations of foraging least terns and piping plovers from 2009-10 at Dinan Tract, near Gibbon, Nebraska

9. Map showing spot-mapped locations of foraging least terns and piping plovers from 2010 at Broadfoot-South Pit, near Kearney, Nebraska ...

10. Map showing spot-mapped locations of foraging least terns from 2009-10 at the Diversion Gates, near Elm Creek, Nebraska. 
11. Map showing spot-mapped locations of foraging least terns and piping plovers from 2009-10 at Bluehole Pit, near Elm Creek, Nebraska...

12. Map showing spot-mapped locations of foraging least terns and piping plovers from 2009-10 at Johnson Pit, near Elm Creek, Nebraska

13. Map showing spot-mapped locations of foraging piping plovers from 2010 at Dyer Pit, near Overton, Nebraska

14. Map showing spot-mapped locations of foraging least terns and piping plovers from 2009-10 at Lexington Pit, near Lexington, Nebraska.

15. Map showing spot-mapped locations of foraging least terns from 2009 at Lexington Island, near Lexington, Nebraska.

\section{Tables}

1. Number of adult piping plovers and least terns to which radio transmitters were applied on the Central Platte River, 2009-10.

2. Locations of telemetry dataloggers used to detect radio-marked least terns and piping plovers on the Central Platte River, 2009-10.

3. Number of noise filtered data records for frequencies of radio transmitters deployed on least terns and piping plovers on the Central Platter River, $2009-10$

4. Distribution of noise filtered data records at noncolony locations for frequencies of radiotransmitters applied to adult piping plovers on the Central Platte River, 2009-10

5. Distribution of noise filtered data records at noncolony locations for frequencies of radiotransmitters applied to adult least terns on the Central Platte River, 2009-10

6. Summary of movement and colony events for radio-marked piping plovers and least terns on the Central Platte River, 2009-10.

7. Number of data collection sessions, length of data collection, and number of recorded all-occurrence behaviors for adult least terns on the Central Platte River in 2009 and 2010

8. Summary of behavioral observation effort by research technicians (sessions, minutes), foraging effort by least terns (plunges, plunge rate, successful plunges, percent success), and success rate by foraging least terns (minutes/ successful plunge) for sandpit and riverine foraging habitats on the Central Platte River, 2009-10

9. Number of behavior data collection sessions and summary of recorded state behaviors for adult piping plovers on the Central Platte River, 2009-10

10. Length of observation time and number of substrate pecks counted for foraging piping plovers on the Central Platte River, 2009-10

11. Frequency of aquatic habitat types at locations where foraging least terns were spot-mapped on the Central Platte River, 2009-10

12. Frequency of terrestrial habitat types at locations where foraging piping plovers were spot-mapped on the Central Platte River, 2009-10

13. Number of samples, fish caught, and fish species collected on the Central Platte River, 2009-10 
14. Number of fish species caught in 189 trawl samples, by location on the Central Platte River, 2009-10.

15. Mean, lower 95-percent confidence limit and upper 95-percent confidence limit for habitat variables measured at least tern foraging locations and random points in sandpits on the Central Platte River, 2009-10.

16. Mean, lower 95-percent confidence limit and upper 95-percent confidence limit for habitat variables measured at least tern foraging locations and random points at river sites on the Central Platte River, 2009-10

17. Number of large (greater than 3 millimeters) and small (less than 3 millimeters) invertebrates caught on sticky traps during 33 sampling sessions on the Central Platte River, 2009-10.

18. Mean, lower 95-percent confidence limit, and upper 95-percent confidence limit for habitat variables measured at piping plover foraging locations and random points on the Central Platte River, 2009-10.

19. Number and fate of least tern nests monitored on the Central Platte River, 2009-10

20. Number and fate of piping plover nests monitored on the Central Platte River, 2009-10

21. Banding and marking records for least tern and piping plover adults on the Central Platte River, 2009-10.

22. Banding and marking records for least tern and piping plover chicks on the Central Platte River, 2009-10.

\section{Appendix Table}

2-1. Daubenmire classification of cover. 


\section{Conversion Factors}

SI to Inch/Pound

\begin{tabular}{|c|c|c|}
\hline Multiply & By & To obtain \\
\hline \multicolumn{3}{|c|}{ Length } \\
\hline centimeter $(\mathrm{cm})$ & 0.3937 & inch (in.) \\
\hline millimeter (mm) & .03937 & inch (in.) \\
\hline meter $(\mathrm{m})$ & 3.281 & foot $(\mathrm{ft})$ \\
\hline kilometer (km) & .6214 & mile (mi) \\
\hline kilometer $(\mathrm{km})$ & .5400 & mile, nautical (nmi) \\
\hline meter $(\mathrm{m})$ & 1.094 & yard (yd) \\
\hline \multicolumn{3}{|c|}{ Area } \\
\hline square meter $\left(\mathrm{m}^{2}\right)$ & 0.0002471 & acre \\
\hline hectare (ha) & 2.471 & acre \\
\hline square meter $\left(\mathrm{m}^{2}\right)$ & 10.76 & square foot $\left(\mathrm{ft}^{2}\right)$ \\
\hline square centimeter $\left(\mathrm{cm}^{2}\right)$ & .1550 & square inch $\left(\mathrm{ft}^{2}\right)$ \\
\hline hectare (ha) & .003861 & square mile $\left(\mathrm{mi}^{2}\right)$ \\
\hline
\end{tabular}

Temperature in degrees Celsius $\left({ }^{\circ} \mathrm{C}\right)$ may be converted to degrees Fahrenheit $\left({ }^{\circ} \mathrm{F}\right)$ as follows:

$$
{ }^{\circ} \mathrm{F}=\left(1.8 x^{\circ} \mathrm{C}\right)+32
$$

Temperature in degrees Fahrenheit $\left({ }^{\circ} \mathrm{F}\right)$ may be converted to degrees Celsius $\left({ }^{\circ} \mathrm{C}\right)$ as follows:

$$
{ }^{\circ} \mathrm{C}=\left({ }^{\circ} \mathrm{F}-32\right) / 1.8
$$

Horizontal coordinate information is referenced to the North American Datum of 1983 (NAD 83). 



\title{
Foraging Ecology of Least Terns and Piping Plovers Nesting on Central Platte River Sandpits and Sandbars
}

\author{
By Mark H. Sherfy, Michael J. Anteau, Terry L. Shaffer, Marsha A. Sovada, and Jennifer H. Stucker
}

\section{Abstract}

Federally listed least terns (Sternula antillarum) and piping plovers (Charadrius melodus) nest on riverine sandbars on many major midcontinent river systems. On the Central Platte River, availability of sandbar habitat is limited, and both species nest on excavated sandpits in the river's floodplain. However, the extent to which sandpit-nesting birds use riverine habitats for foraging is unknown. We evaluated use of foraging habitats by least terns and piping plovers by collecting data on movements, behavior, foraging habitat, and productivity. We radiomarked 16 piping plovers and 23 least terns in 2009-2010 and monitored their movements using a network of fixed telemetry dataloggers. Piping plovers were detected primarily by the datalogger located in their nesting sandpit, whereas least terns were more frequently detected on dataloggers outside of the nesting sandpit. Telemetry data and behavioral observations showed that least terns tended to concentrate at the Kearney Canal Diversion Gates, where forage fish were apparently readily available. Fish sampling data suggested that forage fish were more abundant in riverine than in sandpit habitats, and behavioral observations showed that least terns foraged more frequently in riverine than in sandpit habitats. Piping plovers tended to forage in wet substrates along sandpit shorelines, but also used dry substrates and sandpit interior habitats. The greater mobility of least terns makes a wider range of potential foraging habitats available during brood rearing, making them able to exploit concentrations of fish outside the nesting colony. Thus, our data suggest that different spatial scales should be considered in managing nesting and foraging habitat complexes for piping plovers and least terns.

\section{Introduction}

The Central Platte River Valley (CPRV) is a resource area of continental significance to a variety of migratory birds (Krapu and others, 2004). Habitats and foods provided in this area are important for migration and successful breeding in many species, including waterfowl, shorebirds, and passerines (Sherfy and others, 2011). The CPRV also provides breeding habitat for a variety of migratory birds, including Federally endangered interior least terns (Sternula antillarum) and threatened piping plovers (Charadrius melodus; Faanes, 1983; Sidle and Kirsch, 1993; Jenniges and Plettner, 2008). Both of these species nest throughout the northern Great Plains, co-occurring on many large mid-continent river systems where they nest in loosely organized mixed colonies (Thompson and others, 1997; Haig and Elliott-Smith, 2004; Sherfy and others, 2012; Catlin and others, 2011).

Prior to human alteration, the Platte River probably supported nesting least terns and piping plovers on midchannel sandbars that were largely devoid of vegetation because of high spring flows (Ziewitz and others, 1992). Modification of the river's flow pattern has lowered the frequency and intensity of high water events, resulting in vegetation encroachment and stabilization of sandbars (Sidle and others, 1989). This has led to declining quality and abundance of unvegetated sand nesting habitat favored by least terns and piping plovers (Faanes, 1983; Sidle and Kirsch, 1993; Ziewitz and others, 1992). Foraging habitat for piping plovers, consisting of sparsely vegetated moist or dry sand with high invertebrate production, has probably also declined in quality and abundance. However, least terns forage on small fish in side channels, sloughs, tributaries, shallow-water habitats adjacent to sandbars, and in the main channel (Wilson and others, 1993; Stucker and others, 2011). Therefore, changing quality and abundance of least tern foraging habitat are probably more linked to Platte River flow and water quality than to vegetation dynamics on midchannel sandbars.

A substantial sand and gravel excavation industry has developed in the Platte River floodplain, resulting in numerous sandpits in close proximity to the river channel. These sandpits often contain abundant unvegetated sand that can provide suitable nesting habitat for least terns and piping plovers (Faanes, 1983; Sidle and Kirsch, 1993; Kirsch, 1996; Jenniges and Plettner, 2008). Sandpits often contain impounded water and moist sand that can provide suitable foraging habitat for least terns and piping plovers. This emergence of suitable habitat features on sandpits in conjunction with declining quality of riverine habitat features has been a major factor in the distribution of nesting least terns and piping plovers. The majority of nesting effort in the CPRV in recent years has occurred on sandpits, although the incidence of nesting on sandbars was 
higher in 2007 and 2008 than in previous years (Platte River Recovery Implementation Program, 2008).

Adult least terns and piping plovers differ in their means of obtaining food and in the degree of parental care offered to young. Piping plovers produce precocial young that forage for invertebrates alongside adults (Haig and Elliott-Smith, 2004). Thus, breeding habitats must contain nesting areas and foraging habitat to support both adults and flightless young. However, adult piping plovers may be more flexible in their use of foraging habitat during courtship and nesting, exploiting high-quality foraging areas within flight distance of nesting territories. Least terns produce semi-altricial young that are incapable of acquiring food and are provisioned by adults carrying fish back to nesting colonies (Thompson and others, 1997). Consequently, adult least terns are not constrained to foraging within their nesting colonies during brood rearing and can select the highest quality foraging habitats within profitable traveling distance of their nest sites. These differences in development of young and use of foraging habitats may have consequences for management of nesting habitats, particularly where single management strategies are intended to have multispecies benefits.

Least terns and piping plovers in the CPRV nest primarily in sandpit habitats, possibly because of the greater abundance of unvegetated sand in this habitat type than on riverine sandbars (Sidle and Kirsch, 1993; Platte River Recovery Implementation Program, 2008). There is substantial management interest in restoring a wide variety of habitat conditions that were present prior to human alteration. In the case of nesting habitats for least terns and piping plovers, the principal means of achieving this goal is vegetation removal on midchannel sandbars. Although it is known that least terns and piping plovers favor sandy substrates with sparse to absent vegetation for nesting, the extent to which these habitats must be linked to suitable foraging habitat is not known, as is the suite of features that define suitable foraging habitat.

Linkages between foraging and nesting habitat also are important to understanding the relative role and value of different nesting habitats in supporting productive least tern and piping plover populations. For example, if birds nesting in both of the principal breeding habitats (sandpits and sandbars) tend to prefer feeding in only one of these habitats, then management efforts might focus on improving access to foods in the lesser-used foraging habitat, or focus nesting habitat conservation on habitats closely linked to foraging habitat.

\section{Objectives}

This report summarizes data collected to answer four specific objectives that were developed to collectively contribute to understanding of foraging habitat use by adult least terns and piping plovers in the CPRV:

1. Movements - Quantify frequency and distance of movements away from nesting colonies for least terns and piping plovers nesting in sandpit and riverine sandbar habitats.

2. Time allocation-Quantify time allocation to foraging and foraging success rate for adult least terns and piping plovers in sandpit and riverine sandbar habitats.

3. Foraging Habitat- Quantify features of foraging habitats used by adult least terns and piping plovers during nesting and brood rearing in sandpit and riverine habitats.

4. Productivity-Evaluate linkages between indices of productivity and measures of foraging effort for adult least terns and piping plovers nesting in sandpit and riverine sandbar habitats.

\section{Study Areas}

This study addressed the population of interior least terns and piping plovers that nests within the CPRV, defined as a 3.5-mile buffer of the Platte River between Lexington and Chapman, Nebraska. Within this area, the Platte River Recovery Implementation Program (PRRIP) monitored least tern and piping plover productivity on 28 sites during 2007, including 12 sandbar and 16 sandpit sites. However, efforts in 2009-10 were focused on sites where the highest numbers of least tern and piping plover nests previously had occurred. Based on PRRIP (2008) data, four sandpits (Bluehole, Johnson, Lexington, and Dyer Pits) and two sandbars (Dinan Tract and Dipple Tract) were selected as focal areas. Other potential sites for inclusion were sought each year by (1) accompanying PRRIP staff during airboat surveys of the river in June, (2) conducting canoe surveys of the river in May and June, and (3) observing movements and distribution of birds during behavioral observations on the river. Because none of these approaches revealed additional concentrations of nesting birds, work in nesting colonies was limited to the six preselected focal areas. Access limitations precluded data collection at the Dinan Tract in 2010 .

\section{Methods}

\section{Movements}

The goal for collecting movement data was to estimate timing, frequency, and distance moved by birds beyond their nesting colony (hereafter "colony"). Movement data were collected using radiotelemetry with adult birds. Birds on nests were trapped with the goal of deploying radios on eight birds per species on sandpits and eight birds per species on sandbars. The primary method of trapping birds was remote-triggered bow nets (Hill and Talent, 1990), which were deployed 
early or late in the day or when air temperature was between $15^{\circ} \mathrm{C}\left(60^{\circ} \mathrm{F}\right)$ and $32^{\circ} \mathrm{C}\left(90^{\circ} \mathrm{F}\right)$, wind was minimal or not disrupting nests, and there was no precipitation. All trapping took place after at least 1 week of incubation but prior to pipping of eggs. Trapping attempts were aborted if they exceeded 20 minutes (departure of the bird from the nest to completion of the trap attempt). Prior to trap deployment, eggs were exchanged from targeted nests with artificial eggs to reduce potential risk of injury to eggs; real eggs were stored in a small plastic container cushioned with synthetic batting. Once captured, birds were moved to a nearby area away from the colony and other nesting birds. Birds were weighed with a Pesola-type spring scale, bill and culmen depth were measured with calipers, and natural wing chord was measured using a wing rule.

Each adult least tern was banded with a numbered stainless steel band (size 1A) on the lower leg and up to three celluloid bands (XCL) on the upper leg (two bands per leg). However, birds receiving transmitters had the transmitter attached to a numbered aluminum band that was placed on the upper rather than the lower leg. Each adult piping plover was banded with a numbered U.S. Geological Survey (USGS) aluminum band (size 1A) on the upper leg, a light blue Darvic short flag on the opposite upper leg, and up to two Darvic color bands on each of the lower legs. Band and color combinations were coordinated with other agencies and research entities (for example, Platte River Tern and Plover Conservation Partnership) to ensure consistency and to prevent duplicating color combinations. Birds were released adjacent to the colony within 10 minutes of capture and then observed to document resumption of normal behaviors (for example, incubation or foraging).

Holohil BD-2 transmitters (approximately 1.1 grams) were used for both least terns and piping plovers. For terns, the transmitter was secured to the numbered aluminum leg band using dental floss, which deteriorates over time and allows the transmitter to fall off. The leg band/transmitter package was attached to one of the upper legs. One to three smears of indelible marker were applied under the wings, on the side of the breast, or near the vent of radio-marked terns to facilitate identification of radioed birds during behavioral observations. For piping plovers, the transmitter was glued to feathers in the intrascapular region.

Radio-marked birds were monitored using automated dataloggers (ATS R4500S with one or more Yagi antennas), which were programmed to scan all deployed frequencies at a preset interval (every 5-10 minutes). All equipment (dataloggers, receivers, antenna) was housed in blinds or hidden so as not to provide a perch for raptors or other birds. Dataloggers were positioned strategically to provide meaningful records of bird use of target habitats (for example, in colonies where birds are radio marked, adjacent to potential foraging areas). Blinds were positioned so that visits to download data or replace batteries did not disturb nesting or foraging birds; maintenance visits were conducted in conjunction with other field work.
Procedures to filter telemetry data were similar to those used in telemetry studies of least tern movements on the Missouri River. A "beacon" transmitter was positioned in each colony at a location representative of tern and plover nesting habitat. These transmitters were identical to the transmitters deployed on birds but were placed in fixed locations and monitored by the dataloggers.

Detection records of transmitter frequencies represent potential detections of radio-marked birds, but each record at a noncolony location does not necessarily represent a unique movement event. Duration of a movement event could exceed the dataloggers' search interval, resulting in multiple detection records for a single event. Therefore, 1-hour (h) intervals were treated as independent units, with each hour being labeled by its start time (that is " 8 a.m." indicates 8:00-8:59 a.m.). Each hour that contained one or more detections of a radioed bird away from its nesting colony was classified as a movement event, and each hour that contained only detections of a radioed bird at its nesting colony was classified as a colony event. Productivity data (see below) were used to classify each movement event into one of four reproductive stages: incubation (transmitter deployment to nest hatch), brood rearing (nest hatch to fledging or brood mortality), post-fledging (fledging to departure from the study area), and nonbreeding (failed nests, brood mortality).

\section{Behavior}

Behaviors of adult least terns and piping plovers were observed with the principal goal of quantifying time allocation to foraging. Data included measures of timing, frequency, and location of foraging, capture success, and frequency of prey delivery to colonies for least terns. Data were collected from portable blinds or other inconspicuous locations, including blinds established to protect telemetry dataloggers. Observation points included "colony sites," which were within the focal sandpits and sandbars, as well as "noncolony sites," which were near the fixed telemetry stations.

Behavior was observed using binoculars or spotting scopes during 4-h periods between sunrise and sunset (0600-1000, 1200-1600, and 1700-2100 h). The field season was divided into six 2-week blocks, with the goal of obtaining $3 \mathrm{~h}$ of observation at each colony and foraging site for each of the 4-h periods during each 2-week block. Duration of behavior was reported in units of total hours and total minutes (HH:MM).

The data collection approach differed between terns and plovers because of differences between the species in foraging ecology and location. For plovers, an attempt was made to follow focal adults and broods, whereas for terns the focus was on foraging habitats rather than following individual birds. A detailed protocol for collection of behavior data is provided in appendix 1 . 
Foraging Ecology of Least Terns and Piping Plovers Nesting on Central Platte River Sandpits and Sandbars

\section{Foraging Habitat}

Habitat features were quantified at locations where successful foraging by least terns or piping plovers was observed during behavioral observations. At least tern foraging locations, aquatic habitat variables were recorded including water depth, temperature, turbidity, and flow rate. At piping plover foraging locations, a suite of terrestrial habitat variables were collected at 1-square meter $\left(\mathrm{m}^{2}\right)$ quadrats centered on the foraging location. For both least tern and piping plover foraging locations, data were collected at two paired random points within 75 meters (m) of the foraging location. Random points were constrained to be within the same land-cover classification (wet sand) as the foraging location. A detailed terrestrial habitat data collection protocol is provided in appendix 2 .

During 2010, random locations were sampled in sandpit ponds and riverine sites to characterize baseline fish abundance in these habitats.

Trawls were deployed that drew the net horizontally through the surface of the water column for a distance of 50 $\mathrm{m}$. The sampled area of the trawl was $2.16 \mathrm{~m}^{2}$ (width, $2.4 \mathrm{~m}$, depth, $0.9 \mathrm{~m}$; Stucker and others, 2011). All caught fish were identified to species, measured, and counted. The goal was to measure forage abundance biweekly at each location where behavioral data were collected and at chosen river sites. A detailed fish sampling protocol is provided as appendix 3 .

Sticky sticks were used to measure surficial invertebrate abundance at locations where piping plover adults or broods were observed successfully foraging. Identical methods were used in sandpit and sandbar sites. The sampling unit consisted of four paint stir-sticks (two placed vertically and two placed horizontally) covered with Tanglefoot insect trap coating. The traps were deployed for 30-minute intervals, after which all invertebrates greater than 3 millimeters $(\mathrm{mm})$ in size were counted. An attempt was made to measure forage abundance two to three times per week for each pair of plovers. A detailed invertebrate sampling protocol is provided as appendix 4 .

Paper maps or Global Positioning System (GPS) units with mapping capability (Trimble GeoXT) were used to map locations at which foraging least terns or piping plovers were observed. Each foraging location was recorded in a shapefile and the Universal Transverse Mercator (UTM) coordinates were entered into a master database. These data include foraging events observed during behavior data collection sessions as well as opportunistic observations of foraging birds.

\section{Productivity}

The goal was to quantify nest and chick survival for both target habitats (sandpits and sandbars). Suitable nesting habitat was searched in each study site at approximately 2- to 3 -day intervals, and nests were monitored to determine fate. Based on evidence at the nest site, each nest was classified as Known Successful, Probable Successful, Known Failure, Probable Failure, or Unknown. For successful nests, hatched young were captured by hand and a unique combination of color bands was applied. Tern chicks were marked with three celluloid color bands, and chicks surviving to 15 days were recaptured for application of numbered metal leg bands. Plover chicks were marked with a numbered aluminum $1 \mathrm{~A}$ band on the upper leg, a light blue Darvic short flag on the opposite upper leg, and four Darvic color bands on the lower legs.

Resighting data for banded chicks were obtained by visually scanning plover brood-rearing areas and searching suitable habitat for tern and plover chicks. These searches were conducted during visits to each site for other purposes (behavior data collection, nest searching). When necessary to observe band combinations, chicks were briefly (less than 1 minute) picked up and immediately returned to the location where encountered.

\section{Results}

\section{Movements}

In 2009 and 2010, 19 adult plovers and 23 adult terns were radio marked in the CPRV (table 1). Dataloggers were deployed at each of the 6 focal colonies and at 13 off-colony sites that were strategically chosen to detect movements (fig. 1; table 2).

Beacon transmitters were used to filter noise from the data; only records with a signal strength equal to or greater than 70, 37-40 pulses per minute, 3-20 detected pulses, and 5-6 verified pulses were retained. After telemetry data were filtered based on the beacon transmitters, there were 198,591 data records for 2009-10, each record representing a likely detection of a radio-marked bird (table 3 ). Of these records, 41,587 records of transmitter frequencies were at locations other than the nesting colony in which the transmitter was deployed (noncolony records; table 3 ). Noncolony records included 1,612 records for piping plovers (table 4) and 39,975 records for least terns (table 5).

Table 1. Number of adult piping plovers and least terns to which radio transmitters were applied on the Central Platte River, 2009-10.

\begin{tabular}{lcc}
\hline $\begin{array}{c}\text { Site location } \\
\text { (fig. 1) }\end{array}$ & Piping plover & Least tern \\
\hline Bluehole Pit & 6 & 8 \\
Johnson Pit & 2 & 2 \\
Lexington Pit & 5 & 13 \\
Broadfoot-South Pit & 2 & 0 \\
Dyer Pit & 1 & 0 \\
Dinan Tract & 2 & 0 \\
Dippel Tract & 1 & 0 \\
\hline
\end{tabular}




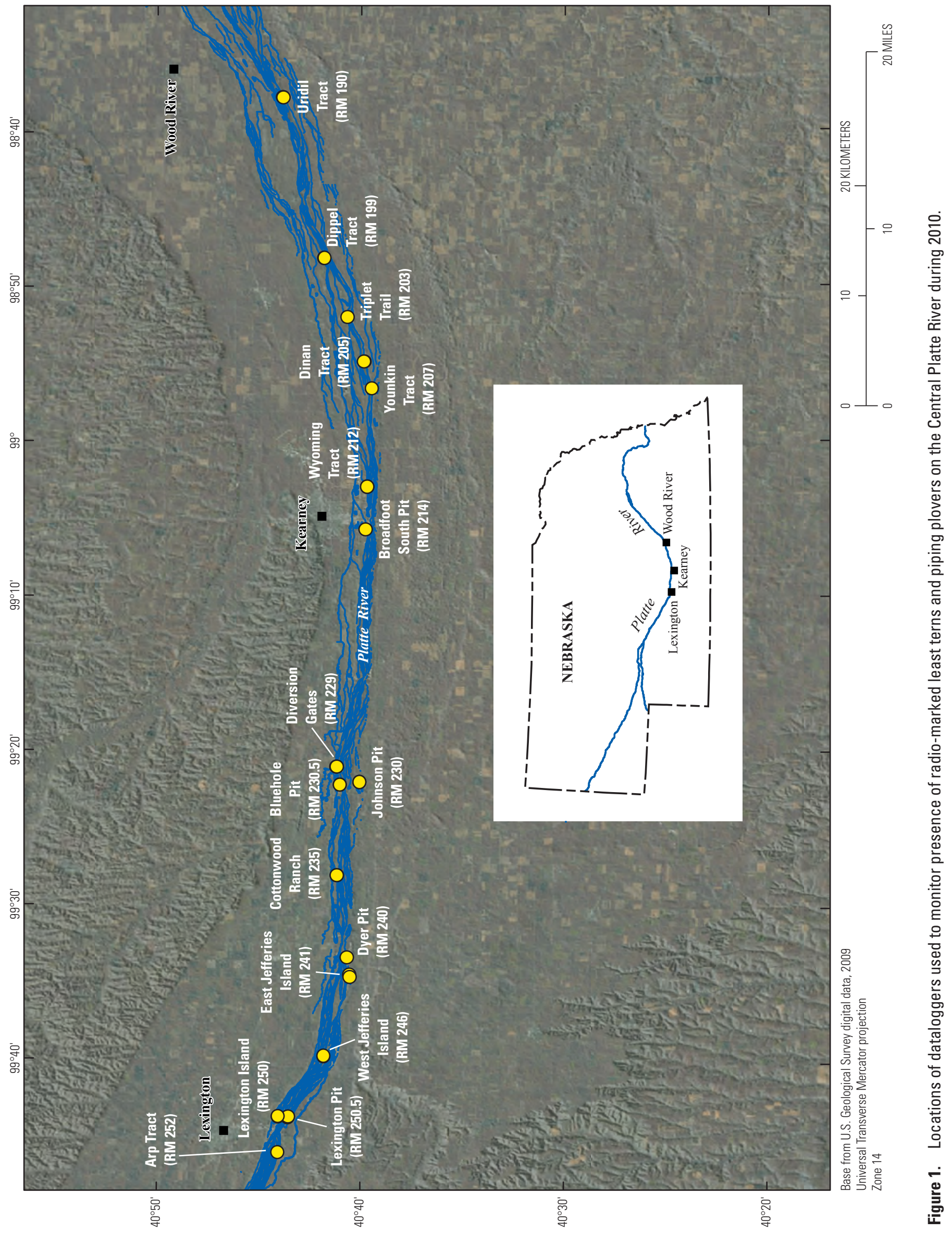


Table 2. Locations of telemetry dataloggers used to detect radio-marked least terns and piping plovers on the Central Platte River, 2009-10.

[Superscripts indicate datalogger was only present for the labeled year; RM, river mile]

\begin{tabular}{ll}
\hline \multicolumn{1}{c}{ Datalogger type } & \multicolumn{1}{c}{ Location } \\
\hline Colony & RM 250.5-Lexington Pit \\
Colony & RM 240-Dyer ${ }^{2010}$ \\
Colony/movement & RM 230.5-Bluehole Pit \\
Colony & RM 214-Broadfoot-South Pit ${ }^{2010}$ \\
Colony/movement & RM 199-Dippel Tract ${ }^{1}$ \\
Movement & RM 252-Arp ${ }^{2010}$ \\
Movement & RM 250-Lexington Island \\
Movement & RM 246-West Jefferies \\
Movement & RM 241-East Jefferies \\
Movement & RM 235-Cottonwood Ranch \\
Movement & RM 229-Diversion Gates \\
Movement & RM 212-Wyoming Tract \\
Movement & RM 207-Younkin Tract ${ }^{2009}$ \\
Movement & RM 203-Triplet Trail ${ }^{2009}$ \\
Movement & RM 205-Dinan Tract \\
Movement & RM 190-Uridil Tract ${ }^{1}$ \\
\hline
\end{tabular}

${ }^{1}$ During high flows (June 23 to July 7, 2010) the Dippel datalogger was moved to the Uridil Tract until flows decreased sufficiently to allow the telemetry station to be returned to its original location without risk of flooding.

Nearly 75 percent of the noncolony detections of piping plovers $(1,207)$ occurred at Bluehole Pit. Birds that were radio-marked at colonies on Johnson Pit, Dyer Pit, and Lexington Pit were also detected at Bluehole Pit (table 4), representing distances of up to 20 river miles from the nesting colony. Sandpits dominated the noncolony detections of piping plovers, with 1,443 detections (90 percent) in this habitat type. Noncolony detections for least terns were more numerous $(39,975)$ than for piping plovers and occurred at many additional sites but rarely occurred at sandpits with only 1,501 detections (4 percent; table 5). Terns from the colony at Johnson Pit primarily were detected at the nearest noncolony dataloggers (Diversion Gates and Bluehole Pit/River), whereas terns from Bluehole Pit and Lexington Pit were detected throughout the Central Platte River (table 5).

Movement events for piping plovers were few (200) and were essentially absent during the postfledging period (1). Colony events $(6,969)$ were much more numerous than movement events for plovers, and four reproductive periods were well represented. However, relatively few colony events were associated with the nonbreeding period (947; 14 percent; table 6).
In contrast, movement events for least terns $(5,495)$ were substantially more abundant than colony events $(2,963)$, and were distributed across all four reproductive periods. Total number of events (movement + colony) during the nonbreeding period for terns was 3,577 , with 50 percent of these $(1,782)$ being colony events. In contrast, 24 percent of events for terns during the other three periods combined $(4,881)$ were colony events.

Despite occurring infrequently in the dataset, there was a distinct pattern of piping plover movement events in relation to time of day. Plover movement events occurred almost exclusively between 8 p.m. and 5 a.m. (113; 86 percent), and infrequently during the daytime hours of 6 a.m. to 7 p.m. (18; 14 percent) (fig. 2). The more frequent movement events of least terns showed a pronounced diurnal pattern, with the majority of movement events $(4,678 ; 82$ percent) occurring between dawn and dusk (4 a.m. to 9 p.m.). Among daytime movement events, there was a pronounced bimodal pattern of frequency, with movements being most frequent in midmorning and late afternoon but dropping off during the midday hours (12 p.m. to 2 p.m.). Tern movement events also occurred throughout the nighttime hours but were substantially less frequent $(968 ; 18$ percent) than during daytime (fig. 3). This pattern held through all stages of the reproductive cycle, although the bimodal distribution was most pronounced and the overall frequency of movement events was greatest for nonbreeding and brood-rearing stages, and least for the incubation and postfledging stages (fig. 4). There were too few movement events for piping plovers to make similar assessments of variation across reproductive stages.

Each movement event represented an hour of the day during which multiple detections on dataloggers could occur. A maximum distance was assigned to each event as the farthest distance between the bird's nesting colony and the dataloggers on which it was detected. The mean of these maximum movement distances for least terns was greatest when movement frequency was lowest (during nighttime hours) and was lowest when movement frequency was greatest (during daytime hours; fig. 5). This pattern remained evident through all reproductive stages, with the longest movement distances occurring during nonbreeding and postfledging periods, and the shortest movement distances occurring during incubation and brood rearing (fig. 6).

\section{Behavior}

Behavioral observations were conducted on least terns during 378 sessions occurring between June and August 2009-10 and on piping plovers during 237 sessions occurring between May and August 2009-10. A total of 21 noncolony observation sessions were conducted on piping plovers in 2010 during airboat river surveys by the PRRIP and during canoe river behavior observations by the USGS. 
Table 3. Number of noise filtered data records for frequencies of radio transmitters deployed on least terns and piping plovers on the Central Platter River, 2009-10.

\begin{tabular}{|c|c|c|c|c|c|}
\hline Frequency & Year & Species & Total records & Noncolony records & Noncolony (percent) \\
\hline 169.18 & 2009 & Least tern & 1,146 & 858 & 74.9 \\
\hline 169.207 & 2009 & Least tern & 8 & 8 & 100 \\
\hline 169.295 & 2009 & Least tern & 5,480 & 1,073 & 19.6 \\
\hline 169.309 & 2009 & Least tern & 2,211 & 2,073 & 93.8 \\
\hline 169.321 & 2009 & Least tern & 16,588 & 3,881 & 23.4 \\
\hline 169.333 & 2009 & Least tern & 5,643 & 3,260 & 57.7 \\
\hline 169.357 & 2009 & Least tern & 1,246 & 190 & 15.2 \\
\hline 169.37 & 2009 & Least tern & 4,543 & 1,760 & 38.7 \\
\hline 169.382 & 2009 & Least tern & 2,189 & 498 & 22.8 \\
\hline 169.408 & 2009 & Least tern & 7,036 & 4,033 & 57.3 \\
\hline 169.522 & 2009 & Least tern & 2,250 & 1,632 & 72.5 \\
\hline 169.558 & 2009 & Least tern & 1,830 & 1,236 & 67.5 \\
\hline 169.621 & 2009 & Least tern & 142 & 34 & 23.9 \\
\hline 170.358 & 2009 & Least tern & 5,691 & 2,348 & 41.3 \\
\hline 170.443 & 2009 & Least tern & 7,245 & 945 & 13 \\
\hline 170.472 & 2009 & Least tern & 9,254 & 2,189 & 23.7 \\
\hline 169.347 & 2010 & Least tern & 9,878 & 2,956 & 29.9 \\
\hline 169.383 & 2010 & Least tern & 1,253 & 1,253 & 100 \\
\hline 169.395 & 2010 & Least tern & 4,607 & 4,607 & 100 \\
\hline 169.507 & 2010 & Least tern & 802 & 802 & 100 \\
\hline 169.535 & 2010 & Least tern & 5,689 & 1,675 & 29.4 \\
\hline 169.571 & 2010 & Least tern & 209 & 209 & 100 \\
\hline 169.658 & 2010 & Least tern & 4,055 & 2,455 & 60.5 \\
\hline 169.008 & 2009 & Piping plover & 912 & 2 & .22 \\
\hline 169.068 & 2009 & Piping plover & 247 & 0 & 0 \\
\hline 169.106 & 2009 & Piping plover & 36 & 0 & 0 \\
\hline 169.132 & 2009 & Piping plover & 57 & 0 & 0 \\
\hline 169.155 & 2009 & Piping plover & 20,800 & 0 & 0 \\
\hline 169.22 & 2009 & Piping plover & 1448 & 0 & 0 \\
\hline 169.119 & 2010 & Piping plover & 10,811 & 1 & .009 \\
\hline 169.131 & 2010 & Piping plover & 7,200 & 144 & 2 \\
\hline 169.309 & 2010 & Piping plover & 10,391 & 0 & 0 \\
\hline 169.321 & 2010 & Piping plover & 14,687 & 0 & 0 \\
\hline 169.37 & 2010 & Piping plover & 15,486 & 0 & 0 \\
\hline 169.708 & 2010 & Piping plover & 66 & 0 & 0 \\
\hline 169.73 & 2010 & Piping plover & 997 & 117 & 11.7 \\
\hline 169.745 & 2010 & Piping plover & 3,158 & 1,210 & 38.3 \\
\hline 169.757 & 2010 & Piping plover & 3,143 & 1 & .032 \\
\hline 169.845 & 2010 & Piping plover & 0 & 0 & 0 \\
\hline 169.857 & 2010 & Piping plover & 2,022 & 0 & 0 \\
\hline 170.405 & 2010 & Piping plover & 6,212 & 22 & .35 \\
\hline 170.444 & 2010 & Piping plover & 1,923 & 115 & 6 \\
\hline
\end{tabular}


Table 4. Distribution of noise filtered data records at noncolony locations for frequencies of radiotransmitters applied to adult piping plovers on the Central Platte River, 2009-10.

[RM, river mile; n, number; double asterisks (**) represent the corresponding colony datalogger]

\begin{tabular}{lccccccc}
\hline $\begin{array}{c}\text { Datalogger location } \\
\text { (fig. 1) }\end{array}$ & $\begin{array}{c}\text { RM 199- } \\
\text { Dippel Tract } \\
(\mathbf{n}=\mathbf{1})\end{array}$ & $\begin{array}{c}\text { RM 214- } \\
\text { Broadfoot-South Pit } \\
(\mathbf{n = 2})\end{array}$ & $\begin{array}{c}\text { RM 230- } \\
\text { Johnson Pit } \\
(\mathbf{n}=\mathbf{2})\end{array}$ & $\begin{array}{c}\text { RM 230.5- } \\
\text { Bluehole Pit } \\
(\mathbf{n}=\mathbf{6})\end{array}$ & $\begin{array}{c}\text { RM 240- } \\
\text { Dyer Pit } \\
(\mathbf{n}=\mathbf{1})\end{array}$ & $\begin{array}{c}\text { RM 250.5- } \\
\text { Lexington Pit } \\
(\mathbf{n}=5)\end{array}$ & Total \\
\hline RM 205-Dinan Tract & 0 & 117 & 0 & 0 & 0 & 0 & 117 \\
RM 214-Broadfoot-South Pit ${ }^{1}$ & 0 & $* *$ & 0 & 1 & 0 & 0 & 1 \\
RM 229-Diversion Gates & 0 & 0 & 0 & 2 & 0 & 0 & 2 \\
RM 230-Johnson Pit & 0 & 0 & $* *$ & 0 & 1 & 5 & 6 \\
RM 230.5-Bluehole Pit/River & 0 & 0 & 144 & $* *$ & 962 & 101 & 1,207 \\
RM 235-Cottonwood Ranch & 1 & 0 & 0 & 0 & 1 & 0 & 2 \\
RM 241-East Jefferies & 0 & 0 & 0 & 0 & 24 & 0 & 24 \\
RM 250-Lexington Island & 0 & 0 & 0 & 0 & 3 & 31 & 34 \\
RM 250.5-Lexington Pit & 0 & 0 & 0 & 0 & 219 & $* *$ & 219 \\
\hline
\end{tabular}

${ }^{1} 2010$ only.

Table 5. Distribution of noise filtered data records at noncolony locations for frequencies of radiotransmitters applied to adult least terns on the Central Platte River, 2009-10.

[RM, river mile; n, number; double asterisks $(* *)$ represent the corresponding colony datalogger; --, no data]

\begin{tabular}{|c|c|c|c|c|}
\hline $\begin{array}{l}\text { Datalogger location } \\
\text { (fig. 1) }\end{array}$ & $\begin{array}{c}\text { RM 230- } \\
\text { Johnson Pit } \\
(n=2)\end{array}$ & $\begin{array}{c}\text { RM 230.5- } \\
\text { Bluehole Pit } \\
(n=8)\end{array}$ & $\begin{array}{c}\text { RM 250.5- } \\
\text { Lexington Pit } \\
(n=13)\end{array}$ & Total \\
\hline RM 190-Uridil Tract & 0 & 64 & 121 & 185 \\
\hline RM 199-Dippel Tract & 0 & 452 & 169 & 621 \\
\hline RM 203-Triplet Trail ${ }^{1}$ & 0 & 116 & 906 & 1,022 \\
\hline RM 205-Dinan Tract & 0 & 161 & 669 & 830 \\
\hline RM 207-Younkin Tract ${ }^{1}$ & 0 & 400 & 935 & 1,335 \\
\hline RM 212-Wyoming Tract & 0 & 10 & 110 & 120 \\
\hline RM 214-Broadfoot-South Pit ${ }^{2}$ & 0 & 213 & 115 & 328 \\
\hline RM 229-Diversion Gates & 1,378 & 10,814 & 364 & 12,556 \\
\hline RM 230-Johnson Pit & $* *$ & 4,371 & 238 & 4,609 \\
\hline RM 230.5-Bluehole Pit/River & 1,738 & $* *$ & 283 & 2021 \\
\hline RM 235-Cottonwood Ranch & 18 & 1,058 & 162 & 1,238 \\
\hline RM 240-Dyer Pit ${ }^{2}$ & 0 & 45 & 337 & 382 \\
\hline RM 241-East Jefferies & 0 & 73 & 1,582 & 1,655 \\
\hline RM 246-West Jefferies & 0 & 234 & 2,990 & 3,224 \\
\hline RM 250-Lexington Island & -- & 83 & 6,517 & 6,600 \\
\hline RM 250.5-Lexington Pit & 0 & 165 & $* *$ & 165 \\
\hline RM 252-Arp Tract ${ }^{2}$ & 0 & 15 & 3,069 & 3,084 \\
\hline
\end{tabular}


Table 6. Summary of movement and colony events for radio-marked piping plovers and least terns on the Central Platte River, 2009-10.

[Percentages (number in parentheses) reflect distribution of events within species and event types]

\begin{tabular}{|c|c|c|c|c|}
\hline \multirow[b]{2}{*}{ Reproductive stage } & \multicolumn{2}{|c|}{ Movement events } & \multicolumn{2}{|c|}{ Colony events } \\
\hline & $\begin{array}{l}\text { Piping plovers } \\
\text { (percent) }\end{array}$ & $\begin{array}{c}\text { Least terns } \\
\text { (percent) }\end{array}$ & $\begin{array}{l}\text { Piping plovers } \\
\text { (percent) }\end{array}$ & $\begin{array}{c}\text { Least terns } \\
\text { (percent) }\end{array}$ \\
\hline Incubation & $81(40)$ & $859(16)$ & $1,956(28)$ & $296(10)$ \\
\hline Brood rearing & 78 (39) & $1,445(26)$ & $2,007(29)$ & $546(18)$ \\
\hline Postfledging & $1(1)$ & $1,396(25)$ & $2,059(30)$ & $339(11)$ \\
\hline Nonbreeding & $40(20)$ & $1,795(33)$ & 947 (14) & $1,782(60)$ \\
\hline Total & 200 & 5,495 & 6,969 & 2,963 \\
\hline
\end{tabular}

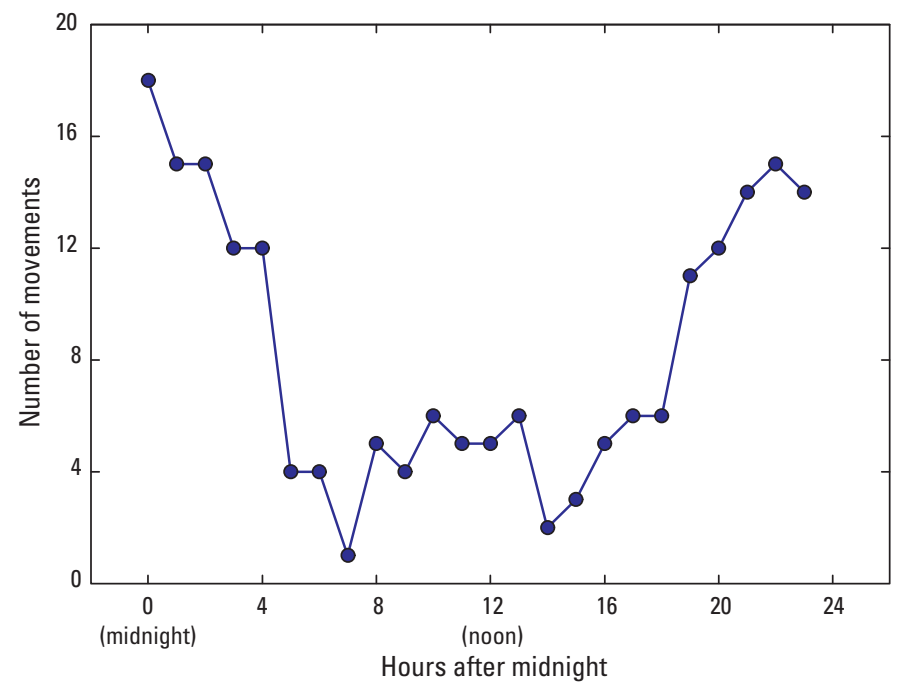

Figure 2. Distribution of movement events across hours of the day for radio-marked piping plovers on the Central Platte River, 2009-10.

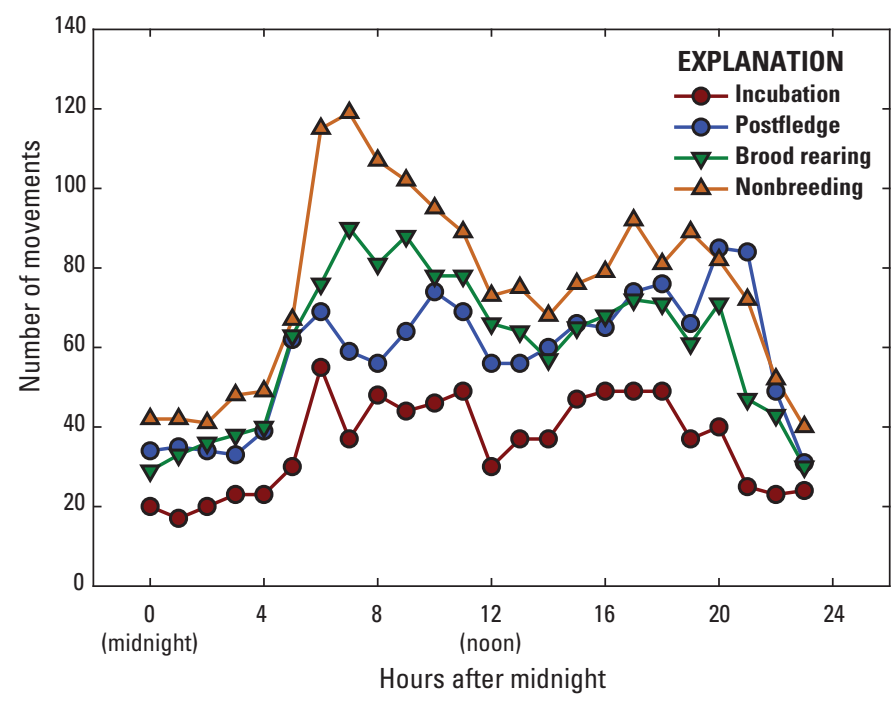

Figure 4. Distribution of movement events across hours of the day for radio-marked least terns during four stages of the reproductive cycle on the Central Platte River, 2009-10.

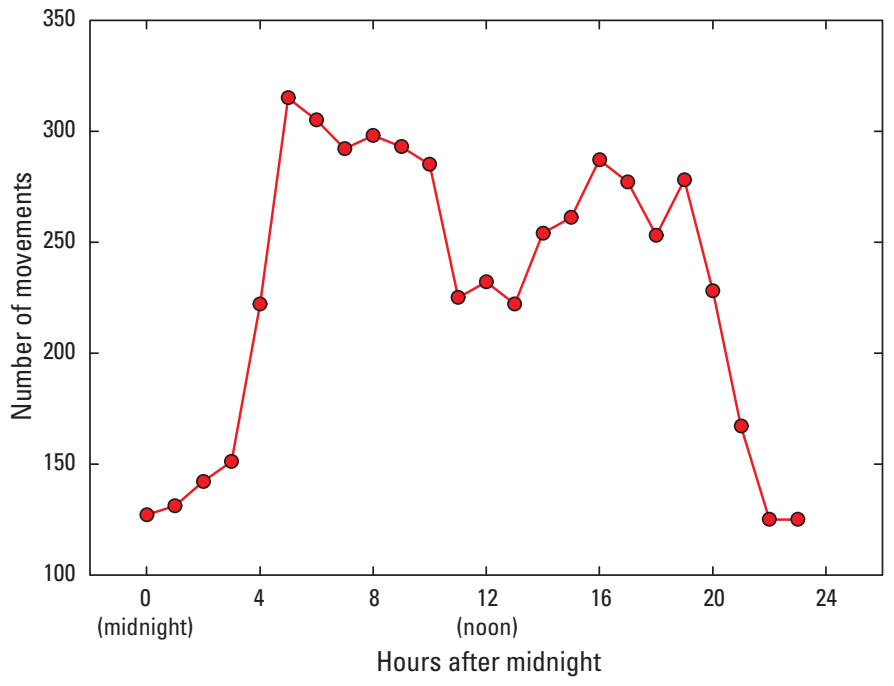

Figure 3. Distribution of movement events across hours of the day for radio-marked least terns on the Central Platte River, 2009-10.

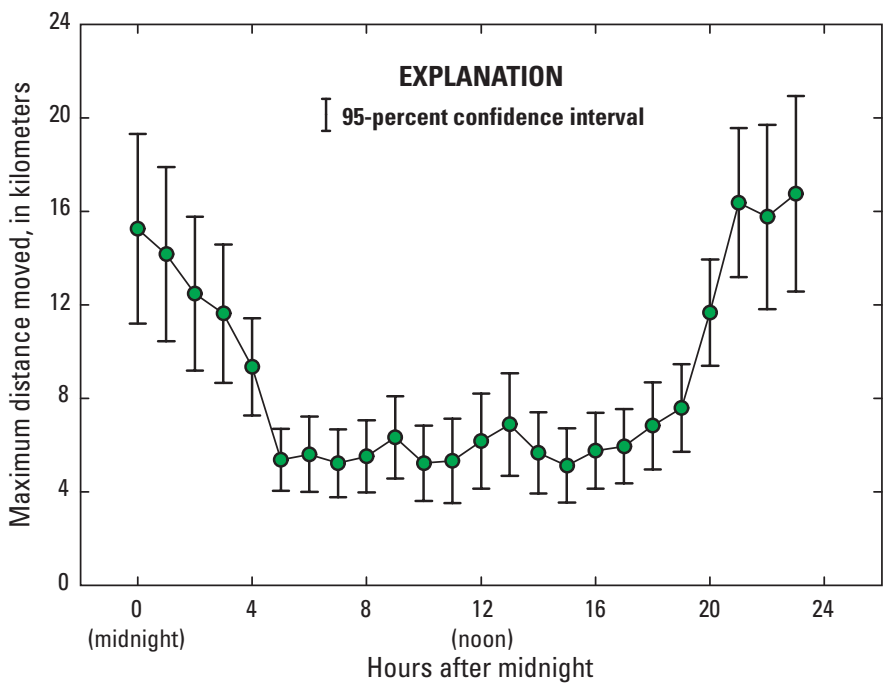

Figure 5. Mean maximum distance (plus or minus 95-percent confidence interval) moved by radio-marked least terns across hours of the day on the Central Platte River, 2009-10. 


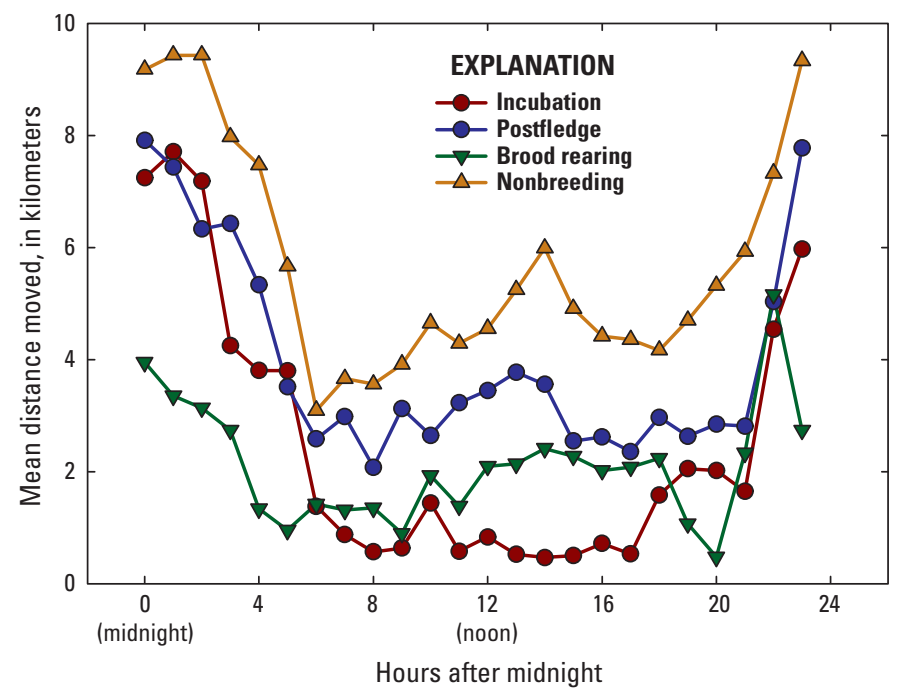

Figure 6. Mean maximum distance moved by radio-marked least terns across hours of the day during four stages of the reproductive cycle on the Central Platte River, 2009-10.
Number and total time of behavior observation sessions for least terns were heavily skewed toward sandpits (tables 7 and 8). Despite this allocation of technician effort toward sandpit observations, foraging effort by terns was substantially higher on river sites. Total number of plunges observed on the river $(8,139)$ was over 10 times higher than on sandpits (770), and foraging plunges were over 20 times more frequent on river sites ( 1.09 per observation minute) than on sandpit sites ( 0.05 per observation minute). Total number of successful plunges also was substantially higher on the river (552; 7 percent success rate) than on sandpit ponds $(7 ; 0.9$ percent success rate). Scaled to technician observation time, successful plunges by terns occurred once every 2,002 minutes on sandpit ponds and once every 13.5 minutes on river sites (table 8 ).

Early in the study recognition was made that terns frequently were observed at the Kearney Canal Diversion Gates, and that this site might represent a profitable tern foraging location. A substantial amount of the river observation effort was spent at this site (76:33), with the remaining time (47:18) distributed among 27 other river sites. When data were

Table 7. Number of data collection sessions, length of data collection, and number of recorded all-occurrence behaviors for adult least terns on the Central Platte River in 2009 and 2010.

\begin{tabular}{|c|c|c|c|c|c|c|c|c|c|c|c|c|c|c|}
\hline \multirow[b]{2}{*}{$\begin{array}{l}\text { Location } \\
\text { (fig. 1) }\end{array}$} & \multirow[b]{2}{*}{ Sessions } & \multirow[b]{2}{*}{$\begin{array}{c}\text { Length } \\
\text { of time } \\
\text { hour: } \\
\text { minute }\end{array}$} & \multicolumn{12}{|c|}{ All-occurrence behaviors } \\
\hline & & & Carry & Eat & $\begin{array}{c}\text { Forage } \\
\text { deliver } \\
\text { adult }\end{array}$ & $\begin{array}{c}\text { Forage } \\
\text { deliver } \\
\text { chick }\end{array}$ & $\begin{array}{c}\text { Forage } \\
\text { deliver } \\
\text { unknown }\end{array}$ & Hover & Leave & $\begin{array}{l}\text { Out of } \\
\text { view }\end{array}$ & $\begin{array}{c}\text { Plunge } \\
\text { not } \\
\text { sucess- } \\
\text { ful }\end{array}$ & $\begin{array}{l}\text { Plunge } \\
\text { success }\end{array}$ & $\begin{array}{c}\text { Plunge } \\
\text { unknown }\end{array}$ & Total \\
\hline RM 192.5 & 1 & $0: 05$ & 0 & 0 & 0 & 0 & 0 & 0 & 0 & 0 & 0 & 0 & 0 & 0 \\
\hline $\begin{array}{c}\text { RM 199- } \\
\text { Dippel } \\
\text { Tract }\end{array}$ & 20 & $15: 34$ & 5 & 1 & 5 & 0 & 0 & 232 & 1 & 12 & 70 & 12 & 58 & 396 \\
\hline $\begin{array}{l}\text { RM 203- } \\
\quad \text { Triplet Trail }\end{array}$ & 1 & $1: 01$ & 0 & 0 & 0 & 0 & 0 & 0 & 0 & 0 & 0 & 0 & 0 & 0 \\
\hline RM 204 & 1 & $0: 08$ & 1 & 1 & 2 & 0 & 0 & 7 & 0 & 1 & 2 & 3 & 0 & 17 \\
\hline $\begin{array}{l}\text { RM 205- } \\
\text { Dinan Tract }\end{array}$ & 15 & $14: 54$ & 16 & 4 & 4 & 3 & 2 & 99 & 1 & 14 & 39 & 6 & 25 & 213 \\
\hline $\begin{array}{l}\text { RM 212- } \\
\text { Wyoming } \\
\text { Tract }\end{array}$ & 3 & $2: 19$ & 2 & 1 & 1 & 0 & 0 & 23 & 1 & 4 & 7 & 3 & 4 & 46 \\
\hline RM 213.5 & 2 & $0: 26$ & 3 & 0 & 0 & 1 & 1 & 40 & 0 & 1 & 14 & 2 & 6 & 68 \\
\hline RM 213.9 & 1 & $0: 07$ & 1 & 0 & 0 & 0 & 0 & 13 & 0 & 0 & 7 & 1 & 0 & 22 \\
\hline $\begin{array}{l}\text { RM 214- } \\
\text { Broadfoot- } \\
\text { South Pit }\end{array}$ & 10 & $9: 49$ & 1 & 2 & 4 & 0 & 0 & 1 & 0 & 0 & 2 & 0 & 0 & 10 \\
\hline RM 214.1 & 1 & $0: 03$ & 0 & 0 & 0 & 0 & 0 & 3 & 0 & 1 & 0 & 0 & 0 & 4 \\
\hline RM 228 & 1 & $0: 12$ & 0 & 0 & 0 & 0 & 0 & 0 & 0 & 0 & 0 & 0 & 0 & 0 \\
\hline
\end{tabular}


Table 7. Number of data collection sessions, length of data collection, and number of recorded all-occurrence behaviors for adult least terns on the Central Platte River in 2009 and 2010.-Continued

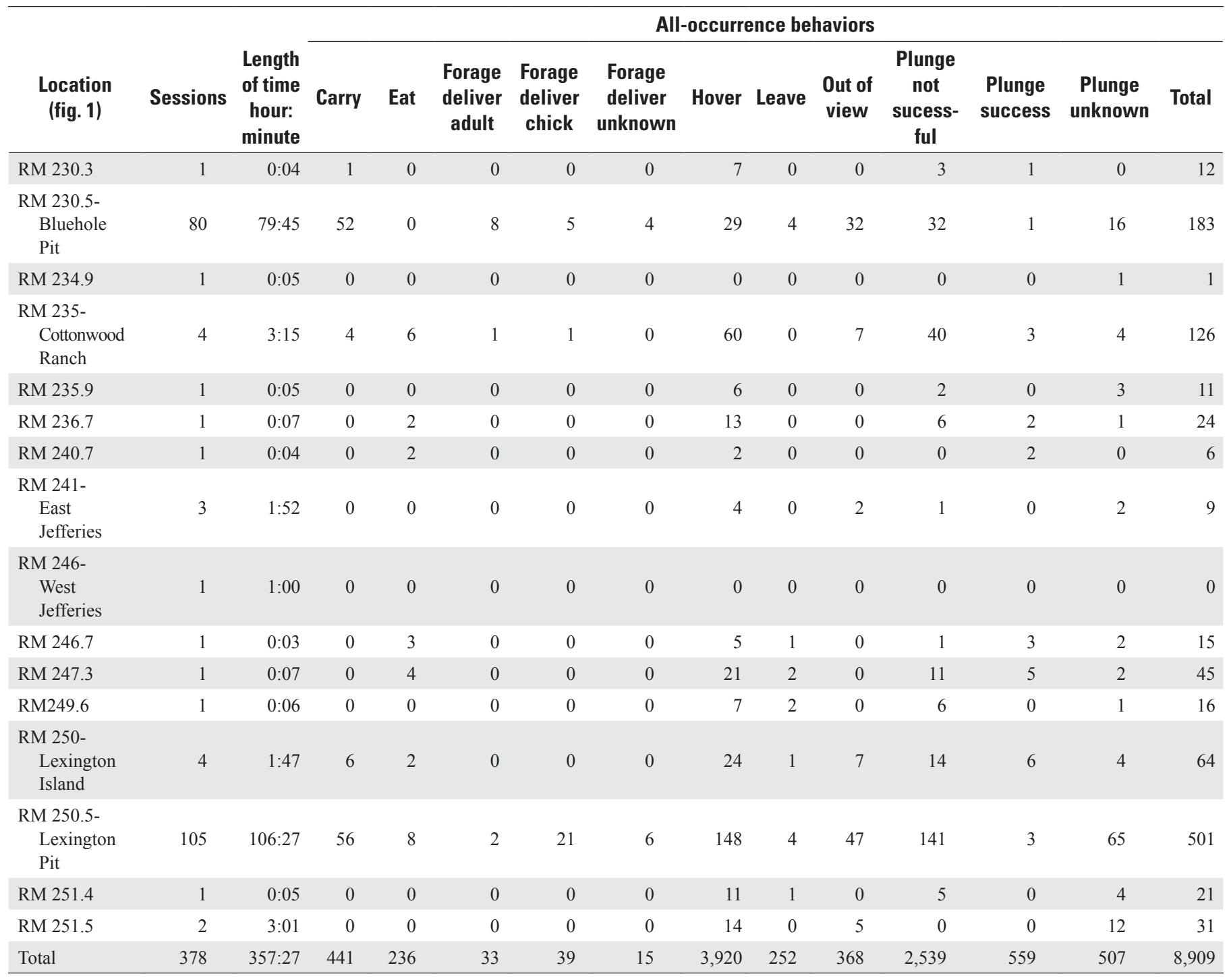

Table 8. Summary of behavioral observation effort by research technicians (sessions, minutes), foraging effort by least terns (plunges, plunge rate, successful plunges, percent success), and success rate by foraging least terns (minutes/successful plunge) for sandpit and riverine foraging habitats on the Central Platte River, 2009-10.

[--, not calculated because rates and percentages are only meaningful within habitat types]

\begin{tabular}{|c|c|c|c|c|c|c|c|}
\hline & Sessions & Minutes & Plunges & $\begin{array}{c}\text { Plunge rate } \\
\text { (plunges per } \\
\text { minute) }\end{array}$ & $\begin{array}{l}\text { Successful } \\
\text { plunges }\end{array}$ & $\begin{array}{c}\text { Success } \\
\text { (percent) }\end{array}$ & $\begin{array}{c}\text { Minutes per } \\
\text { success }\end{array}$ \\
\hline Sandpit & 230 & 14,017 & 770 & 0.05 & 7 & 0.9 & 2,002 \\
\hline River & 148 & 7,431 & 8,139 & 1.09 & 552 & 7 & 13.5 \\
\hline Total & 378 & 21,447 & 8,909 & -- & 559 & -- & -- \\
\hline
\end{tabular}


examined separately for the Diversion Gates site the foraging effort was found to be slightly higher at the Diversion Gates (1.5 plunges/minute) than at other river sites ( 0.4 plunges/ minute), and foraging success was also slightly higher at the Diversion Gates ( 7 percent) than at other river sites (4 percent). Successful plunges by terns occurred more frequently at this site (once every 9.1 minutes) than at other river sites (once every 57.9 minutes). However, foraging frequency and success were still higher at river sites than sandpit ponds when the Diversion Gates data were excluded.

The majority of observation sessions $(203 / 237 ; 86$ percent; table 9) and time (103:49/107:49; 96 percent; table 10) for piping plovers occurred on 5 sandpits where plovers nested, while the remaining observations occurred across 17 river sites. During 3,880 minutes of observation for foraging adult plovers on sandpits, 8,645 pecks were counted for a total peck rate of 2.2 pecks/minute. Adult plovers foraged less intensively on river sites, with an overall peck rate of 9.2 pecks/minute. Nearly all of the observation time for chicks came from sandpit sites (1,978 minutes for sandpits, 200 minutes for river sites), but chick foraging rates were similar between habitat types (12.9 pecks/minute on sandpits, $11.0 \mathrm{pecks} /$ minute on river sites).

\section{Foraging Habitat}

Least tern foraging observations in 2009-10 were spotmapped at 3,138 locations. Main and braided channels were the dominant habitats at foraging sites, with the majority of observations occurring at the Kearney Canal Diversion Gates (table 11). Foraging tern locations spot-mapped in 4 sandpit ponds accounted for less than 9 percent of the total number of observations (table 9). A total of 1,164 locations of foraging piping plovers were spot-mapped, of which 98 percent occurred within nesting colonies (4 sandpits, 1 sandbar; table 12). Plovers foraged primarily in wet sand habitat on sandpits and river sites, with about 28 percent of locations occurring in dry sand. Spatial distributions of spot-mapped foraging locations for 2009-10 are shown in figures 7-15 (at the back of this report).

A total of 189 fish trawl samples were collected in 2009-10 (table 13). Fish were sampled every 2 weeks at sites where tern nesting colonies occurred and consistently at three riverine sites. Of the 189 trawl samples, 17 caught no fish. All but two of these occurred in sandpits before mid-June. A total of 12,353 fish were caught, with the greatest number of individuals and fish species occurring at the river sites (tables 13 and 14, at the back of this report). Mean number of fish caught per sample was 34.5 for sandpits and 81.9 for river sites. The relatively high fish abundance on river sites was not an artifact of high fish abundance at the Diversion Gates, as this site had a mean abundance of 69.6 fish/sample. However, the Diversion Gates site produced more fish species than any other site, including 12 species that were caught only at this site (table 14). The only other site producing unique fish species was Bluehole Pit (two black crappies). Turbidity and water temperature were measured at 22 foraging locations and 44 random locations in sandpits, and 95-percent confidence intervals for both variables overlapped between foraging and random locations (table 15, at the back of this report). Turbidity, water temperature, and velocity were measured at 38 foraging locations and 86 random locations at river sites, and 95-percent confidence intervals for all three variables overlapped between foraging and random locations (table 16, at the back of this report).

Terrestrial surficial forage samples were collected during 33 sampling sessions in 2009-10. Each session consisted of sampling one plover forage location and two paired random points. Samples were collected at the Dinan Tract (2 sessions), Johnson Pit (3 sessions), Bluehole Pit (13 sessions), Dyer Pit (2 sessions), and Lexington Pit (13 sessions). For each sample collected, the number of large (greater than $3 \mathrm{~mm}$ ) and small (less than $3 \mathrm{~mm}$ ) invertebrates was quantified (table 17, at the back of this report). Mean number of large invertebrates per sample appeared comparable between foraging sites (12.7) and random points (13.4). However, sample sizes were low due to low abundance of foraging plovers, particularly at river sites.

The Daubenmire cover classes of terrestrial habitat variables were converted to the midpoint value for the range of percentages represented by the class and then these values were treated as continuous variables (Sherfy and others, 2009). Five variables were excluded from summary because they were essentially absent (boulder, cobble, and large debris) or were meaningless given the sparse vegetation cover on plover foraging sites (maximum vegetation height, mean vegetation height). The remaining variables were measured at 30 foraging locations and 60 random points. Among these points, habitat variables were similar between foraging and random locations, except that wrack tended to be more abundant and terrestrial vegetation less abundant at foraging locations than at random points (table 18, at the back of this report).

\section{Productivity}

A total of 98 least tern nests was monitored in 2009-10; 95 of these were on sandpits, primarily on Bluehole and Lexington Pits (table 19, at the back of this report). We monitored 39 piping plover nests in 2009-10; 31 occurred on sandpits, and 8 occurred on sandbar sites (table 20).

Nest fate determinations were based exclusively on evidence observed at the nest site on the day that monitoring was terminated. Accordingly, nests classified as unknown fate (tables 19-20, at the back of this report) may have hatched. Apparent nest success for least terns was 33 percent (1 successful nest, 3 total nests) on river sites and 51 percent (49 successful and probable successful nests, 95 total nests) on sandpits. Apparent nest success for piping plovers was 25 percent ( 2 successful or probable successful nests, 8 total nests) on river sites and 48 pecent (15 successful or probable successful nests, 31 total nests) on sandpits.

A total of 23 adult least terns, 24 adult piping plovers (table 21, at the back of this report), 109 least tern chicks, and 
Table 9. Number of behavior data collection sessions and summary of recorded state behaviors for adult piping plovers on the Central Platte River, 2009-10.

State behaviors

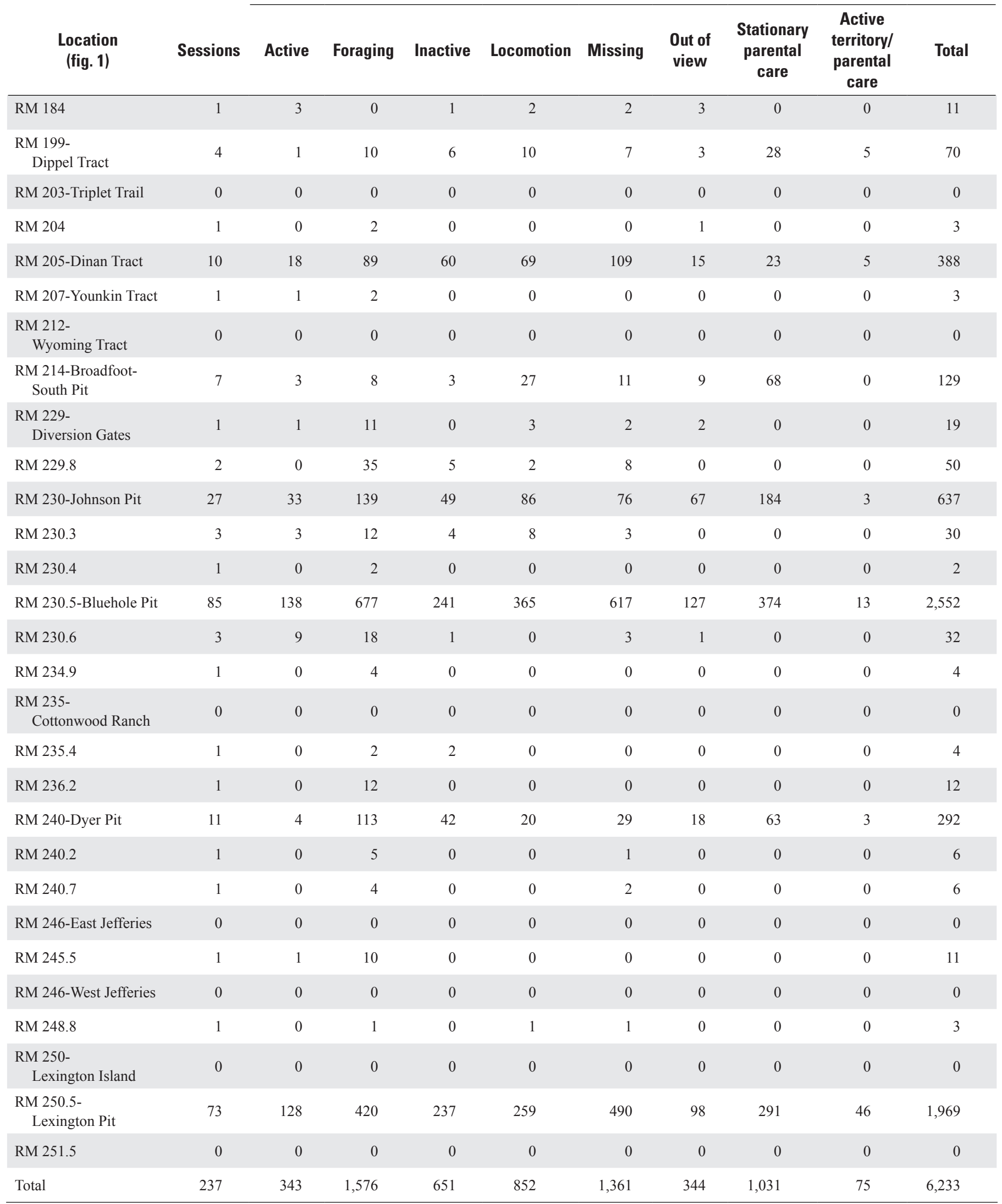


Table 10. Length of observation time and number of substrate pecks counted for foraging piping plovers on the Central Platte River, 2009-10.

[RM, river mile]

\begin{tabular}{|c|c|c|c|c|}
\hline \multirow[b]{2}{*}{$\begin{array}{l}\text { Location } \\
\text { (fig. 1) }\end{array}$} & \multicolumn{2}{|c|}{ Adults } & \multicolumn{2}{|c|}{ Young } \\
\hline & $\begin{array}{c}\text { Time } \\
\text { hours: } \\
\text { minutes }\end{array}$ & Pecks & $\begin{array}{c}\text { Time } \\
\text { hours: } \\
\text { minutes }\end{array}$ & Pecks \\
\hline RM 184 & 0:07 & 9 & 0:00 & 0 \\
\hline RM 199-Dippel Tract & $1: 10$ & 18 & $0: 13$ & 94 \\
\hline RM 203-Triplett Trail & 0:00 & 0 & 0:00 & 0 \\
\hline RM 204 & 0:00 & 7 & 0:00 & 0 \\
\hline RM 205-Dinan Tract & $3: 35$ & 1,405 & $1: 13$ & 561 \\
\hline RM 207-Younkin Tract & 0:05 & 55 & 0:00 & 0 \\
\hline RM 212 & 0:00 & 0 & 0:00 & 0 \\
\hline $\begin{array}{l}\text { RM 214-Broadfoot- } \\
\text { South Pit }\end{array}$ & $3: 43$ & 77 & 0:00 & 0 \\
\hline $\begin{array}{l}\text { RM 229-Diversion } \\
\text { Gates }\end{array}$ & $0: 22$ & 121 & $0: 11$ & 64 \\
\hline RM 229.8 & $0: 37$ & 263 & 0:08 & 30 \\
\hline RM 230-Johnson Pit & $11: 03$ & 793 & $2: 44$ & 2,711 \\
\hline RM 230.3 & 0:00 & 0 & $0: 26$ & 248 \\
\hline RM 230.4 & 0:05 & 105 & 0:00 & 0 \\
\hline RM 230.5-Bluehole Pit & $24: 48$ & 3,738 & $17: 01$ & 12,414 \\
\hline RM 230.6 & 0:04 & 95 & $0: 26$ & 326 \\
\hline RM 234.9 & 0:09 & 259 & 0:00 & 0 \\
\hline RM 235 & 0:00 & 0 & 0:00 & 0 \\
\hline RM 235.4 & 0:00 & 0 & $0: 12$ & 183 \\
\hline RM 236.2 & $0: 36$ & 1,429 & 0:00 & 0 \\
\hline RM 240-Dyer Pit & $2: 49$ & 0 & $2: 58$ & 3,323 \\
\hline RM 240.2 & $0: 01$ & 10 & 0:03 & 34 \\
\hline RM 240.7 & 0:00 & 0 & $0: 10$ & 77 \\
\hline RM 241-East Jefferies & 0:00 & 0 & 0:00 & 0 \\
\hline RM 245.5 & 0:00 & 0 & $0: 18$ & 590 \\
\hline RM 248.8 & 0:00 & 0 & 0:00 & 0 \\
\hline $\begin{array}{l}\text { RM 250-Lexington } \\
\text { Island }\end{array}$ & 0:00 & 0 & 0:00 & 0 \\
\hline $\begin{array}{l}\text { RM 250.5-Lexington } \\
\quad \text { Pit }\end{array}$ & $22: 17$ & 4,037 & $10: 15$ & 7,062 \\
\hline RM 251.5 & 0:00 & 0 & 0:00 & 0 \\
\hline Total & $71: 31$ & 12,421 & $36: 18$ & 27,717 \\
\hline
\end{tabular}

Table 11. Frequency of aquatic habitat types at locations where foraging least terns were spot-mapped on the Central Platte River, 2009-10.

[RM, river mile]

\begin{tabular}{lrccc}
\hline $\begin{array}{c}\text { Location } \\
\text { (fig. 1) }\end{array}$ & Sandpit & $\begin{array}{c}\text { Main } \\
\text { channel }\end{array}$ & $\begin{array}{c}\text { Braided } \\
\text { channel }\end{array}$ & $\begin{array}{c}\text { Secondary } \\
\text { channel }\end{array}$ \\
\hline RM 199-Dipple Tract & 0 & 0 & 55 & 0 \\
RM 205-Dinan Tract & 0 & 0 & 57 & 0 \\
$\begin{array}{l}\text { RM 214-Broadfoot- } \\
\text { South Pit }\end{array}$ & 5 & 0 & 0 & 0 \\
$\begin{array}{l}\text { RM 229-Diversion } \\
\text { Gates }\end{array}$ & 0 & 1,137 & 1,610 & 9 \\
$\begin{array}{l}\text { RM 230-Johnson Pit } \\
\text { RM 230.5-Bluehole }\end{array}$ & 23 & 0 & 0 & 0 \\
$\quad$ Pit & 27 & 0 & 0 & 0 \\
RM 250-Lexington & 0 & 0 & 3 & 0 \\
$\quad$ Island & & & & \\
RM 250.5-Lexington & 212 & 0 & 0 & 0 \\
$\quad$ Pit & 267 & 1,137 & 1,725 & 9 \\
Total & & &
\end{tabular}

Table 12. Frequency of terrestrial habitat types at locations where foraging piping plovers were spot-mapped on the Central Platte River, 2009-10.

[RM, river mile]

\begin{tabular}{lrcc}
\hline \multicolumn{1}{c}{$\begin{array}{c}\text { Location } \\
\text { (fig. 1) }\end{array}$} & Sandpit & Sandbar & $\begin{array}{c}\text { River } \\
\text { shoreline }\end{array}$ \\
\hline RM 199-Dippel Tract & 0 & 10 & 0 \\
RM 205-Dinan Tract & 0 & 46 & \\
RM 214-Broadfoot-South Pit & 8 & 0 & 0 \\
RM 230-Johnson Pit & 115 & 0 & 0 \\
RM 230.5-Bluehole Pit & 554 & 13 & ${ }^{1} 11$ \\
RM 240-Dyer Pit & 111 & 0 & 0 \\
RM 250.5-Lexington Pit & 296 & 0 & 0 \\
Total & 1,084 & 69 & 11 \\
\hline
\end{tabular}

${ }^{1}$ RM 230.5 sandbar and shoreline observations were made on the Platte River just south of Bluehole Pit. 
Table 13. Number of samples, fish caught, and fish species collected on the Central Platte River, 2009-10.

$[\mathrm{RM}$, river mile]

\begin{tabular}{lccc}
\hline \multicolumn{1}{c}{$\begin{array}{c}\text { Location } \\
\text { (fig. 1) }\end{array}$} & Samples & $\begin{array}{c}\text { Fish } \\
\text { caught }\end{array}$ & $\begin{array}{c}\text { Fish } \\
\text { species }\end{array}$ \\
\hline RM 180 & 3 & 106 & 8 \\
RM 199-Dippel Tract & 9 & 171 & 4 \\
RM 205-Dinan Tract & 17 & 3,552 & 12 \\
RM 212-Wyoming Tract & 3 & 47 & 1 \\
RM 214-Broadfoot-South Pit & 6 & 42 & 3 \\
RM 229-Diversion Gates & 51 & 3,548 & 41 \\
RM 230-River & 4 & 561 & 8 \\
RM 230-Johnson Pit & 18 & 786 & 5 \\
RM 230.5-Bluehole Pit & 18 & 856 & 9 \\
RM 235-Cottonwood Ranch & 3 & 162 & 13 \\
RM 241- East Jefferies & 18 & 620 & 23 \\
RM 246-West Jefferies & 12 & 1,235 & 25 \\
RM 250-Lexington Island & 3 & 69 & 4 \\
RM 250.5-Lexington Pit & 24 & 598 & 7 \\
Total & 189 & 12,353 & \\
\hline
\end{tabular}

89 piping plover chicks was banded in 2009-10 (table 22, at the back of this report). Tern and plover chicks were considered fledged if they survived to 16 and 21 days, respectively, or were observed in flight. Based on these criteria, an estimation was made that 1 banded plover chick fledged from a sandbar, 19 tern chicks fledged from sandpits, and 32 plover chicks fledged from sandpits within the study area in 2009-10.

\section{Discussion}

A motivation for this study was a desire to understand differences in use of foraging habitats by least terns and piping plovers nesting on sandpits and river sandbars. However, nesting effort by both species was very low on sandbars. Only 3 least tern nests and 8 piping plover nests were found on 2 sandbar sites. Low use was further complicated by restrictions on research access to sandbars in 2010, which placed additional constraints on the study's ability to compare these habitat types. Accordingly, rigorous analyses could not be conducted on the role of nest-site habitat type (sandpit compared to sandbar) in use of foraging habitat by Platte River least terns and piping plovers. Although low nesting effort on sandbars is a statistical hurdle, it should not be overlooked as a potential indicator of how terns and plovers perceive habitat conditions. The relative roles of nest-site habitat and foraging habitat in driving selection of nest sites by these species have not been rigorously evaluated. There are certainly some distinct qualitative differences between sandbar and sandpit habitats on the Central Platte River, including topography, elevation profile, grain size, and vegetation community. These factors can be important for tern and plover nest-site selection (Anteau and others, 2012; Sherfy and others, 2011) and a more complete understanding of relations between preferred nestsite features and those available in the Central Platte River will be needed to understand the importance. River sandbars on the nearby Lower Platte River, which are used more frequently by nesting terns (Kirsch, 1996) than Central Platte River sandbars, may be a useful basis for comparing habitat features and understanding lack of use on the Central Platte River.

Proximity and quality of foraging habitat can also potentially influence nest-site selection and productivity (Atwood and Kelly, 1984; Massey and others, 1992; Dugger, 1997; Catlin and others, 2011; Stucker and others, 2011). Least terns are known to forage near their nesting colonies (Faanes, 1983; Wilson and others, 1993; Schweitzer and Leslie, 1996), but the extent to which nesting colony use is constrained by flight distance to foraging areas is poorly known. Telemetry data suggest that nesting least terns are capable of using habitat complexes that span substantial distances, as movement events greater than 10 kilometers $(\mathrm{km})$ regularly occurred in the dataset. Although greater movement distance would equate to greater energetic cost, it is not known how the costs of these larger-scale movements are offset.

The Kearney Canal Diversion Gates (RM 229) was a site at which adult least terns previously were known to be common. At this site, a diversion structure and canal confluence create flow patterns atypical of the Platte River's main channel. Data showed that terns from all nesting colonies were detected at this site, although movements to the Diversion Gates were far more frequent for birds nesting at the nearest colony (Bluehole Pit). Fish sampling data suggested this site is a profitable tern foraging location, containing a relatively high abundance of fish and potentially some taxa relatively uncommon elsewhere in the river system. The foraging frequency and success rates observed at this site suggest terns could more readily obtain forage fish than at other sites. This could be a function of higher fish abundance or enhanced availability because of diversity of flow patterns and structure. Although the Diversion Gates site was heavily used by Bluehole Pit terns (76 percent of movement events by these birds), it was not the most heavily used site by terns from other colonies. For example, terns radio-marked at Lexington Pit were most frequently encountered at two sites within 4 miles of the colony (West Jefferies; 35 percent of movement events and the Arp Tract; 23 percent of movement events). Lexington Pit birds were detected at the Diversion Gates at a frequency slightly higher than other nearby sites, but overall use was substantially lower than by Bluehole Pit birds. These observations suggest that proximity of foraging habitat to a nesting colony is an important factor contributing to its use, and the presence of nearby foraging habitat may enhance use of a nesting colony. 
O'Shea and others (1990) sampled fish in Platte River sandpits and the river's open channel and concluded that differences in flow regime and vegetation community were key factors distinguishing fish assemblages between sandpits and river sites. Wilson and others (1983) found that terns nesting on Platte River sandpits did not forage exclusively on the sandpit but traveled to forage elsewhere and frequently returned from the Platte River carrying fish. Wilson and others (1983) also reported a greater frequency of successful plunges and greater proportion of small fish in the river than in sandpits. The data showed similar patterns of greater plunge frequency, higher foraging success, and higher fish abundance at river sites than in sandpits. Breeding success of California least terns was correlated with proportion of northern anchovies (Engraulis mordax), suggesting that abundance and composition of the prey base can influence tern productivity (Elliott and others, 2007). Although the dataset was sparse, tern productivity was similar on the two sites where the greatest number of adult terns were radio marked (Bluehole and Lexington Pits), suggesting that variable access to prey did not have a differential influence on tern productivity among Platte River sites.

Both river sites and sandpits were used by foraging terns and plovers, but river sites appeared to be more important for tern foraging and sandpits appeared to be more important for plover foraging. Prey sampling data suggested prey abundance may have been partially responsible for these differences in use. Fish tended to be more abundant on river sites, and the single river site sampled for invertebrates had lower abundance than the sandpits sampled. A targeted study would be needed to make reliable conclusions about differences in forage abundance between these habitat types. However, it is probably more important, especially for plovers, to understand the factors that influence nest-site and nest-habitat selection on the Central Platte River. The mobility of terns throughout the reproductive cycle makes a wide range of foraging habitats available, which was evident in the substantial movements throughout the river corridor by sandpit-nesting birds that was observed. In contrast, brood-rearing plovers are constrained to foraging in habitats connected to nesting areas. Consequently, the spatial scale at which habitat complexes (nesting, broodrearing, and foraging) should be managed for these two species is substantially different.

When the mean value of a habitat variable at a used location differs from the value at a random location, selection for that variable can be inferred (Sherfy and others, 2012). Although the sample of plover foraging locations was small, the data indicate that selection may be occurring in two cases. Wrack tended to be more abundant and terrestrial vegetation tended to be less abundant at foraging locations than at random points (table 18). This suggests that plovers may select sites with more wrack and less vegetation for foraging. Presence of wrack could favor abundance of invertebrate prey, whereas lack of vegetation could enhance ability to detect predators. Both features could also be indicators of wet shoreline habitats where plovers preferentially foraged.
Data also have implications for how forage abundance and habitat use of terns and plovers are monitored in the future. Pronounced diurnal variation in frequency of movements outside nesting colonies by both species was documented, with terns more frequently moving outside colonies during daylight hours and plovers more frequently moving outside colonies during nighttime hours. Collectively, movement distance and frequency data for terns suggest that birds made frequent, short-distance movements out of colonies during daylight hours and less frequent, longer-distance movements out of colonies at night. It cannot be conclusively stated that movements by either species were timed to coincide with peaks in prey availability, although piping plovers are known to forage at night in coastal habitats where prey abundance may be higher and human disturbance may be lower at night (Staine and Burger, 1994). Behavioral observations and fish sampling data for terns show that foraging occurred at noncolony sites, and that foraging effort and frequency were higher at river than sandpit sites. Movement frequency and distance increased in later stages of the breeding cycle, suggesting that adult terns explored a wider range of habitats and potentially capitalized on more distant resources when there was a lower premium on colony attendance.

Nocturnal predation has been implicated as a factor contributing to low colony attendance by terns at night (Nisbet, 1975; Nisbet and Welton, 1984; Arnold and others, 2006). However, several factors suggest that nocturnal predation was not the primary influence on nocturnal tern and plover behavior on the Platte River. First, it would be expected that terns and plovers nesting in the same colonies would exhibit similar patterns of response to predation pressure, but the opposite was observed, with tern movements occurring primarily in the daytime and plover movements occurring primarily at night. This observation is consistent with Bluso-Demers and others (2010), who found that colony attendance by Forster's terns (Sterna forsteri) pairs was relatively high at night. Second, Zimmerman (2008) found that temporary predator-mediated desertion of colonies by least terns was brief ( 15.5 plus or minus 3 minutes). In contrast, nocturnal movements by least terns were farther from the colony than daytime movements, and the distances involved (mean distance greater than 10 miles near midnight; fig. 5) likely translated into longer recesses. Third, apparent nest success was around 50 percent for both terns and plovers on sandpits, which is higher than would be expected if predation substantially influenced these sites. Collectively, this evidence suggests that predation pressure was not a principal cause for the movement events that were documented.

\section{Regulatory Compliance}

This research was conducted under a Federal Threatened and Endangered Species Permit (\#TE-121914-5) and a Scientific and Educational Permit from the Nebraska Game and 
Parks Commission. The following observations and incidents of bird death, bird injury, and human disturbance are reported in accordance with these permits for 2010 [comparable information for 2009 is available in Sherfy and others, (2009)].

\section{Injury}

- On June 5 at the Dinan Tract (RM 205) during the release of an adult piping plover, the banding technician felt a pop from the bird's left leg. The adult piping plover was observed not using its left leg but was observed flying and bathing after release.

- On June 25 at the Bluehole Pit (RM 230.5), a banded least tern chick was found with what appeared to be a broken leg and a clamped colored band on the leg. The colored band was removed; the chick was observed twice in the following week.

\section{Death}

- Along the Central Platte River, 3 dead piping plovers ( 1 adult and 2 chicks) and 8 dead least terns (1 adult and 7 chicks) were found in 2010. Some were collected for further examination.

- On May 14, 2010, at the Dippel tract (RM 199), an adult piping plover was found dead. The dead plover's feathers had been plucked and presumed killed by an avian predator. The bird was not collected.

- On June 21, 2010, at the Bluehole Pit (RM230.5), five least tern chicks were found dead in or near nest bowls. An intense storm the previous night/morning might have been the cause of death, but no direct evidence was observed. Two of the chicks were previously banded and all chicks were collected.

- On June 23, 2010, at the Bluehole Pit (RM 230.5), a dead banded piping plover chick was found. A gash in the abdomen was observed; no other evidence was found. Intense storms had occurred the previous two nights. The bird was collected.

- On June 29, 2010, at the Bluehole Pit (RM 230.5), a dead piping plover chick was found with no signs indicating cause of death; the bird was collected.

- On July 3, 2010, at the Bluehole Pit (RM 230.5), a banded least tern chick was found dead with a gash in the abdomen. No other evidence was observed; the bird was collected.

- On July 3, 2010, at the Bluehole Pit (RM 230.5), a dead banded least tern chick was found covered in ants near some wrack. No other signs indicated cause of death; the bird was collected.

- On July 14, 2010, at the Lexington Pit (RM 250.5), a banded adult least tern was found dead. The body had advanced decomposition; therefore cause of death was unknown. Band combination indicated the bird was banded in 2009 as a chick. The bird had primary feathers and likely could fly. It is possible the bird died the previous year. The bird was collected.

\section{Human Disturbance}

No confirmed human disturbance events were observed along the Central Platte River in 2009-10.

\section{References Cited}

Anteau, M.A., Sherfy, M.H., and Wiltermuth, M.T., 2012, Selection indicates preference in diverse habitats-A ground-nesting bird (Charadrius melodus) using reservoir shoreline: PLoS One, v. 7, p. 1-9.

Arnold, J.M., Sabom, D., Nisbet, I.C.T., and Hatch J.J., 2006, Use of temperature sensors to monitor patterns of nocturnal desertion by incubating common terns: Journal of Field Ornithology, v. 77, p. 384-394.

Atwood, J.L., and Kelly, P.R., 1984, Fish dropped on breeding colonies as indicators of least tern food habits: Wilson Bulletin, v. 96, p. 34-47.

Bluso-Demers, J.D., Ackerman, J.T., and Takekawa, J.Y., 2010, Colony attendance patterns by mated Forster's terns Sterna forsteri using an automated data-logging receiver system: Ardea, v. 98, p. 59-65.

Catlin, D.H., Fraser, J.D., Felio, J.H., and Cohen, J.B., 2011, Piping plover habitat selection and nest success on natural, managed, and engineered sandbars: Journal of Wildlife Management, v. 75, p. 305-310.

Dugger, K.M., 1997, Foraging ecology and reproductive success of least terns nesting on the Lower Mississippi River: Columbia, Missouri, University of Missouri, Ph.D. dissertation, $137 \mathrm{p}$.

Elliott, M.L., Hurt, R., and Sydeman, W.J., 2007, Breeding biology and status of the California least tern Sternula antillarum browni at Alamdea Point, San Francisco Bay, California: Waterbirds, v. 30, p. 317-325.

Faanes, C.A., 1983, Aspects of the nesting ecology of least terns and piping plovers in central Nebraska: Prairie Naturalist, v. 15 , p. $145-154$. 
Haig, S.M., and Elliott-Smith, E., 2004, Piping plover, in Poole, A., ed., The Birds of North America: Ithaca, N.Y., Cornell Laboratory of Ornithology.

Hill, L.A., and Talent, L.G., 1990, Effects of capture, handling, banding, and radio-marking on breeding least terns and snowy plovers: Journal of Field Ornithology, v. 61, p. $310-319$.

Jenniges, J.J., and Plettner, R.G., 2008, Least tern nesting at human created habitats in central Nebraska: Waterbirds, v. 31, p. 274-282.

Kirsch, E.M., 1996, Habitat selection and productivity of least terns on the lower Platte River, Nebraska: Wildlife Monographs 132.

Krapu, G.L., Brandt, D.A., and Cox, R.R., Jr., 2004, Less waste corn, more land in soybeans, and the switch to genetically modified crops - Trends with important implications for wildlife management: Wildlife Society Bulletin, v. 3, p. 127-136.

Massey, B.W., Bradley, D.W., and Atwood, J.L., 1992, Demography of a California least tern colony including effects of the 1982-1983 El Niño: Condor, v. 94, p. 976983.

Nisbet, I.C.T, 1975, Selective effects of predation in a tern colony-Condor, v. 77, p. 221-226.

Nisbet, I.C.T., and Welton, M.J., 1984, Seasonal variations in breeding success of common terns: Consequences of predation: Condor, v. 86, p. 53-60.

O'Shea, D.T., Hubert, W.A., and Anderson, S.H., 1990, Assemblages of small fish in three habitat types along the Platte River, Nebraska: Prairie Naturalist, v. 22, p. 145-154.

Platte River Recovery Implementation Program, 2008, Least tern and piping plover monitoring protocol implementation report for 2007: Platte River Recorvery Implementation Program unpublished report, Lincoln, Nebraska.

Schweitzer, S.H., and Leslie, D.M., Jr., 1996, Foraging patterns of the least tern (Sterna antillarum) in north-central Oklahoma: Southwestern Naturalist, v. 41, p. 307-314.

Sherfy, M. H., Anteau, M.J., and Bishop, A.A., 2011, Agricultural practices and residual corn during spring crane and waterfowl migration in Nebraska: Journal of Wildlife Management, v. 75, p. 995-1003.
Sherfy, M.H., Anteau, M.J., Shaffer, T.L., Sovada, M.A., and Stucker, J.H., 2009, Foraging ecology of least terns and piping plovers nesting on Central Platte River sandpits and sandbars - 2009 progress report: U.S. Geological Survey, Northern Prairie Wildlife Research Center, Jamestown, North Dakota unpublished report to the Platte River Recovery Implementation Program, 50 p.

Sherfy, M.H., Stucker, J.H., and Anteau, M.J., 2009, Missouri River emergent sandbar habitat monitoring plan-A conceptual framework for adaptive management: U.S. Geological Survey Open-File Report 2008-1223, 51 p.

Sherfy, M.H., Stucker, J.H., and Buhl, D.A., 2012, Selection of nest-site habitat by interior least terns in relation to sandbar construction: Journal of Wildlife Management, 76:363-371.

Sidle, J.G., and Kirsch, E.M., 1993, Least tern and piping plover nesting at sand pits in Nebraska: Colonial Waterbirds, v. 16, p. 139-148.

Sidle, J.G., Miller, E.D., and Currier, P.J., 1989, Changing habitats in the Platte River Valley of Nebraska: Prairie Naturalist, v. 21, p. 91-104.

Staine, K.J., and Burger, J., 1994, Nocturnal foraging behavior of breeding piping plovers (Charadrius melodus) in New Jersey: The Auk, v. 111, p. 579-587.

Stucker, J.H., Buhl, D.A., and Sherfy, M.H., 2011, Emergent sandbar construction for least terns on the Missouri RiverEffects on forage fishes in shallow-water habitats: River Research and Applications, doi: 10.1002/rra/1525.

Thompson, B.C., Jackson, J.A., Burger, J., Hill, L.A., Kirsch, E.M., and Atwood, J.L., 1997, Least tern (Sterna antillarum), in Poole, A., and Gill, F., eds., The Birds of North America, No. 290: Philadelphia, Penn., The Academy of Natural Sciences, and Washington, D.C., The American Ornithologists' Union.

Wilson, E.C., Hubert, W.A.,and Anderson, S.H., 1993, Nesting and foraging of least terns on sand pits in central Nebraska: Southwestern Naturalist, v. 38, p. 9-14.

Ziewitz, J.W., Sidle, J.G., and Dinan, J.J., 1992, Habitat conservation for nesting least terns and piping plovers on the Platte River, Nebraska: Prairie Naturalist, v. 24, p. 1-20.

Zimmerman, P.P., 2008, Nocturnal predation of California least terns at a southern California least tern colony: Arcata, California, Humboldt State University, thesis. 
Figures 7-15 


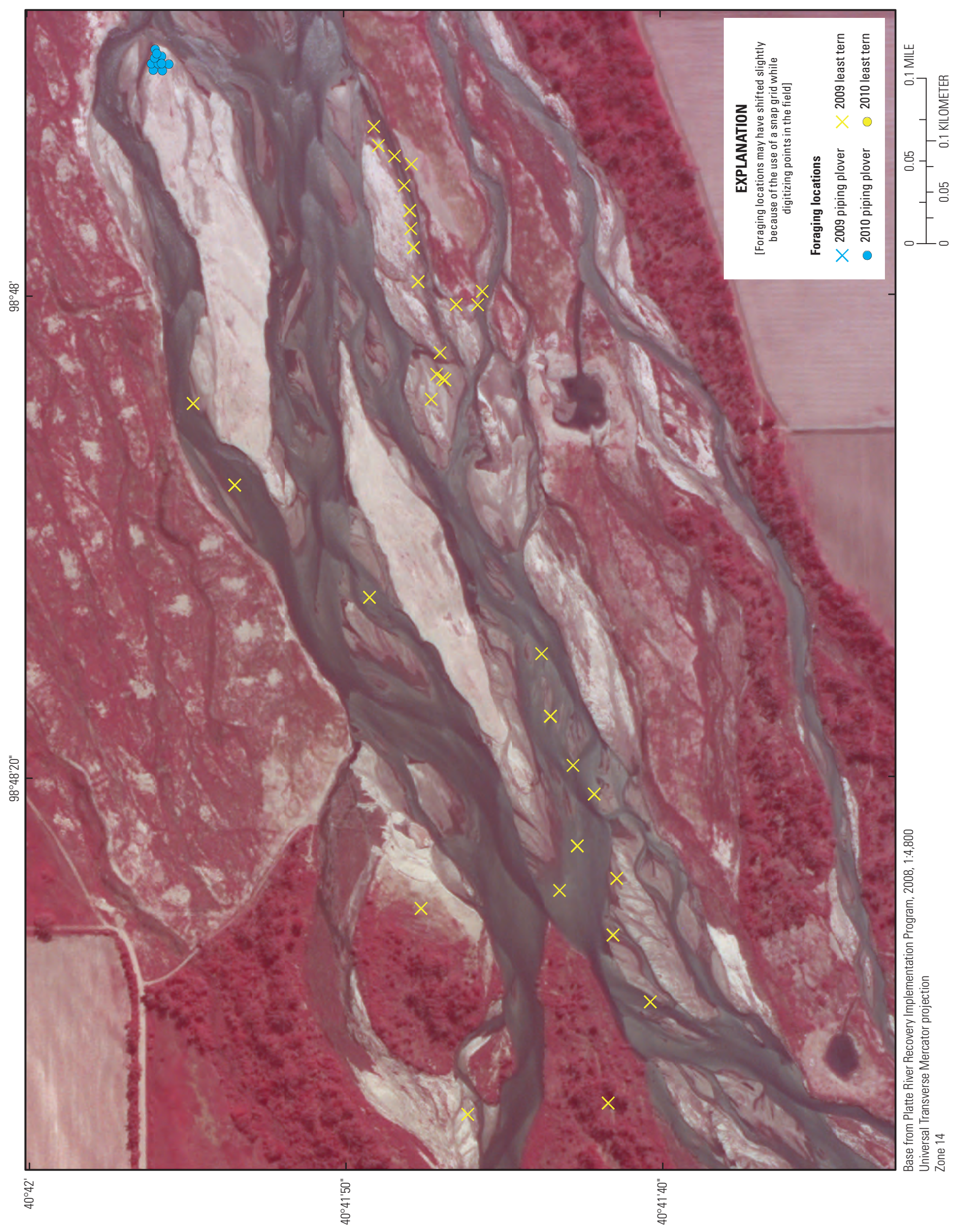

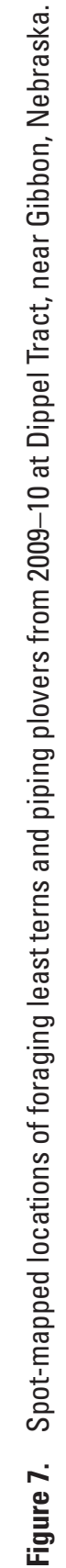




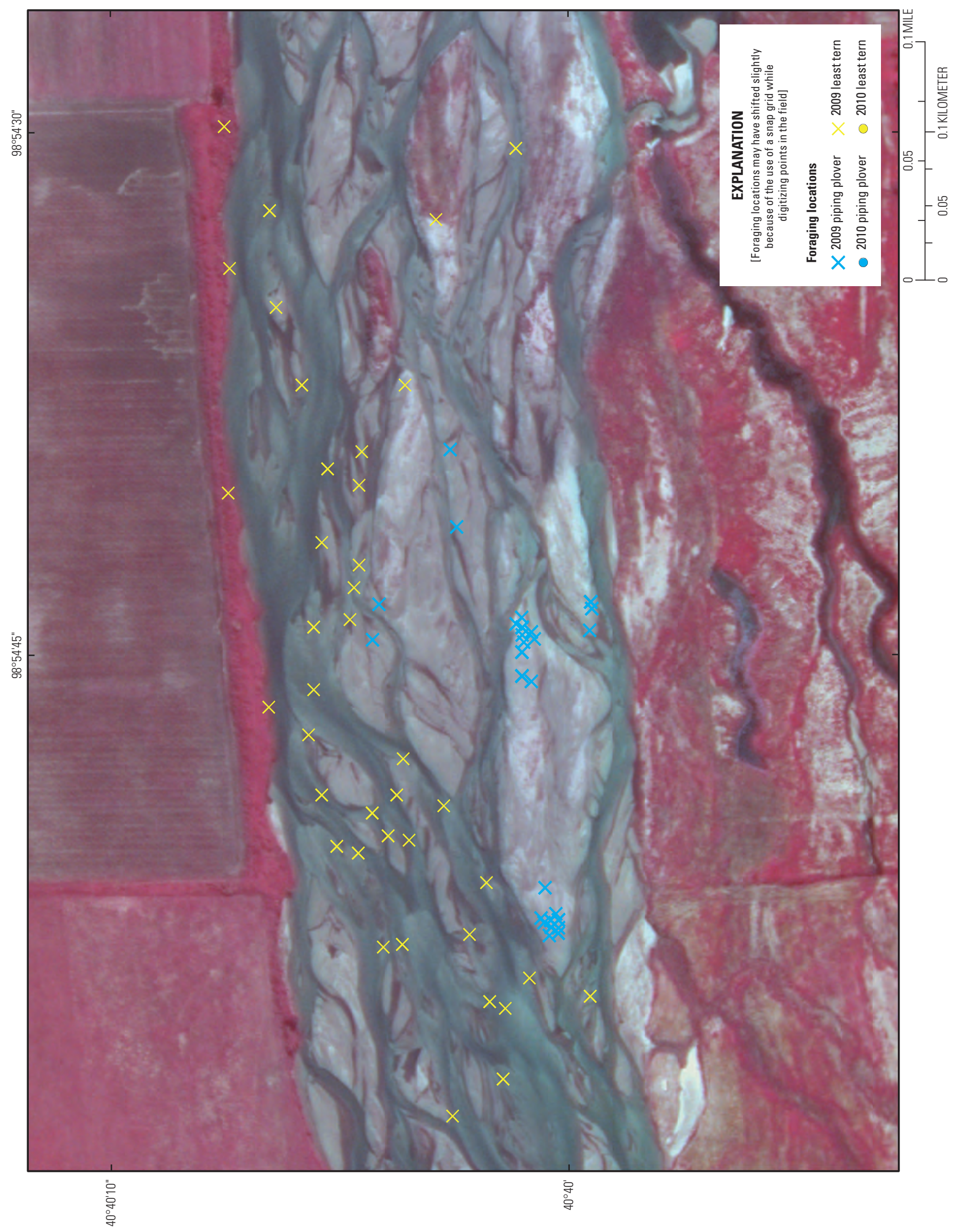

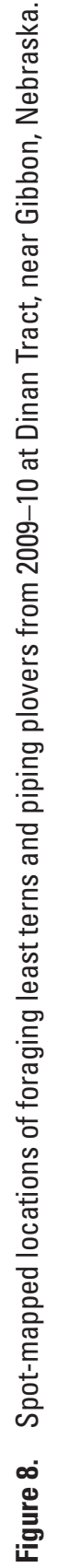




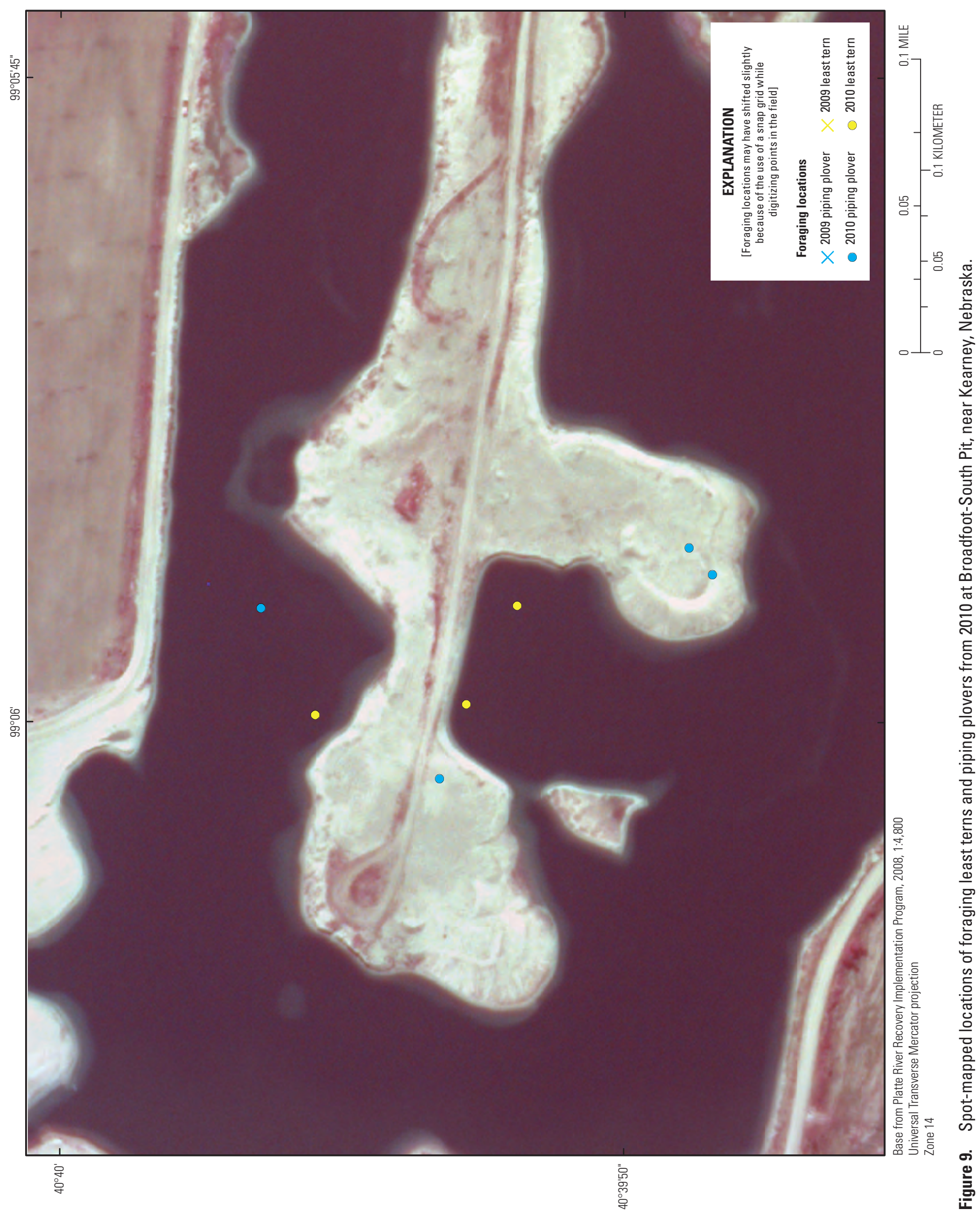




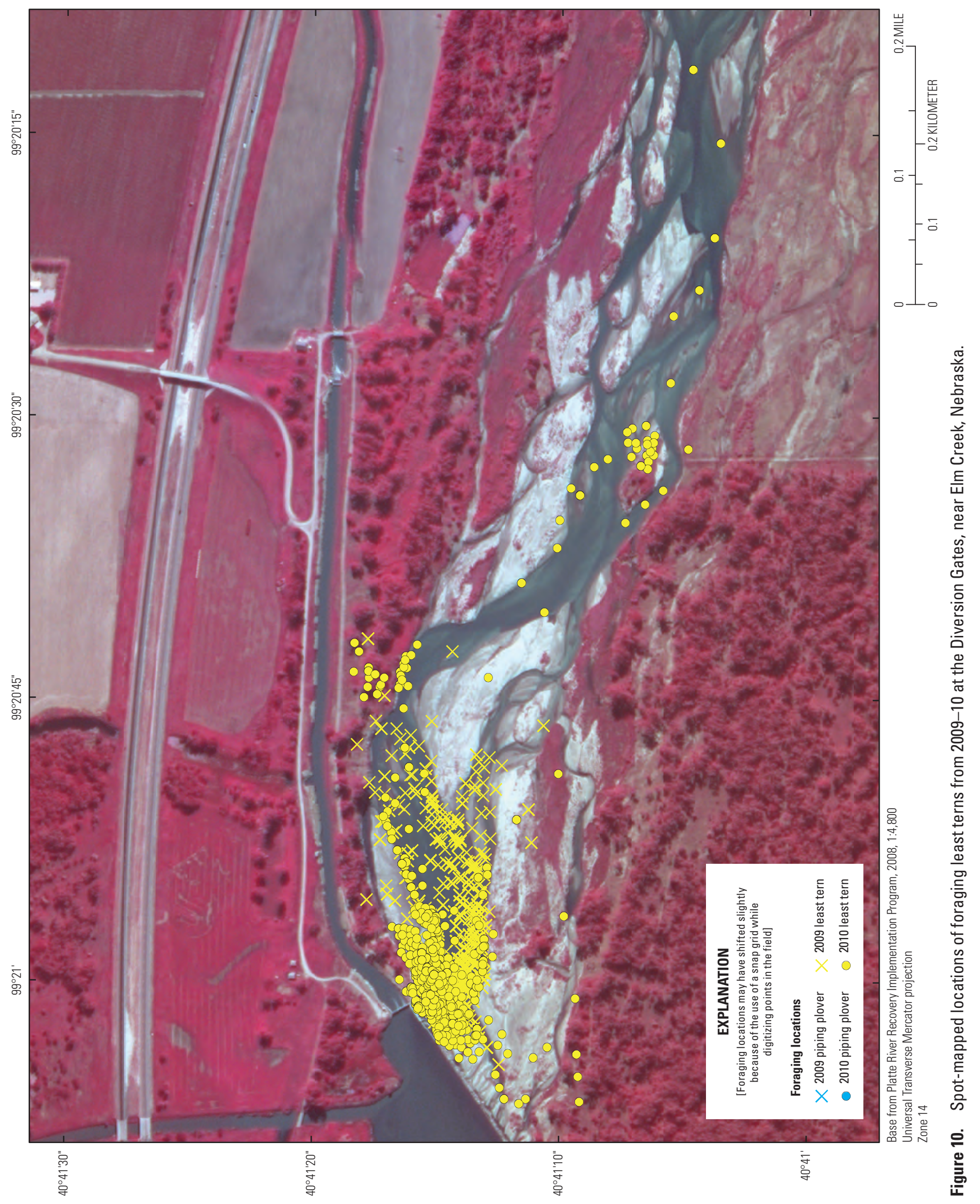




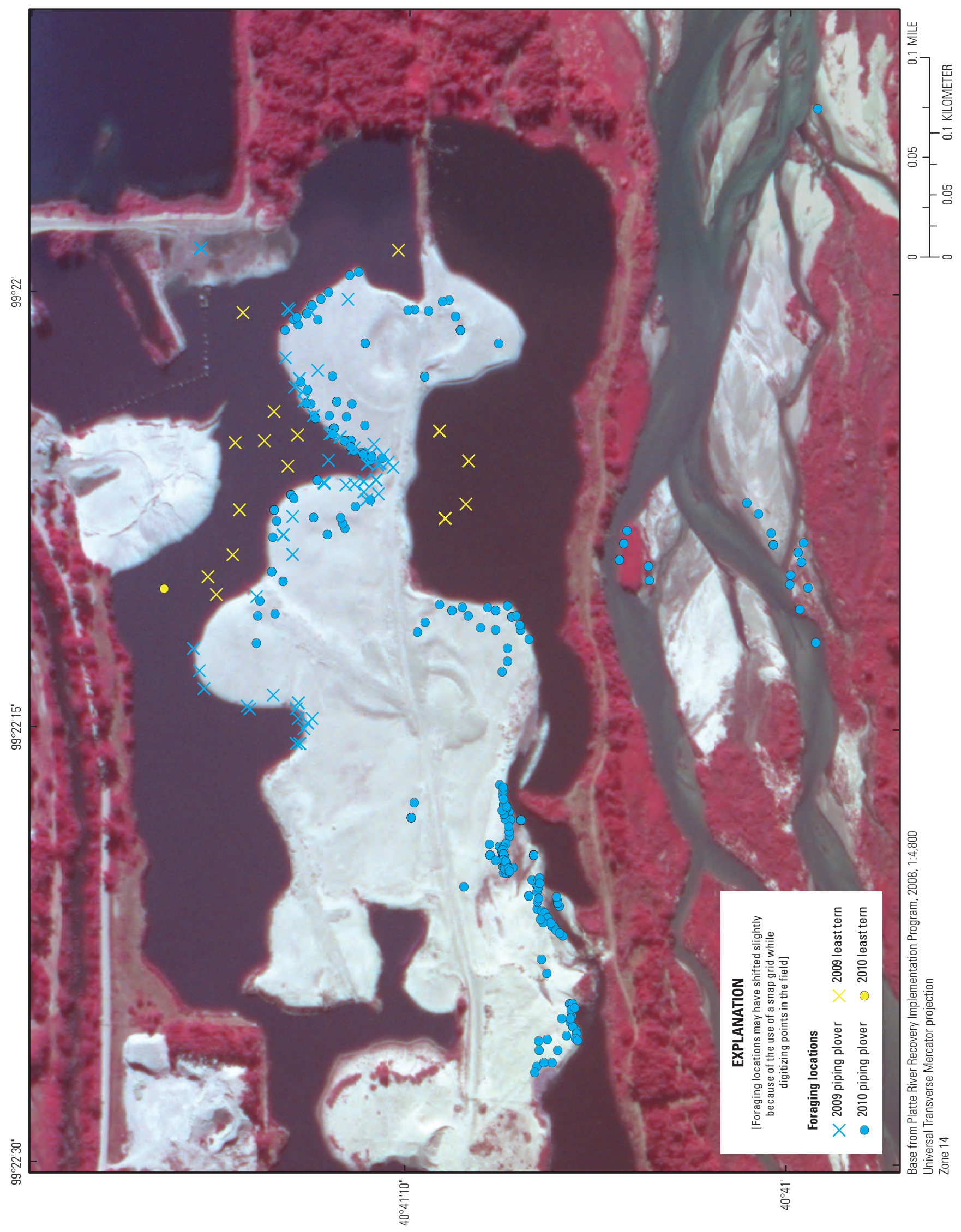

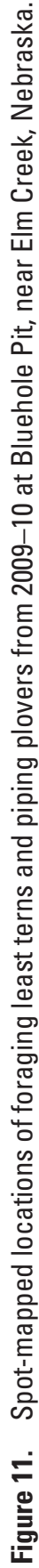




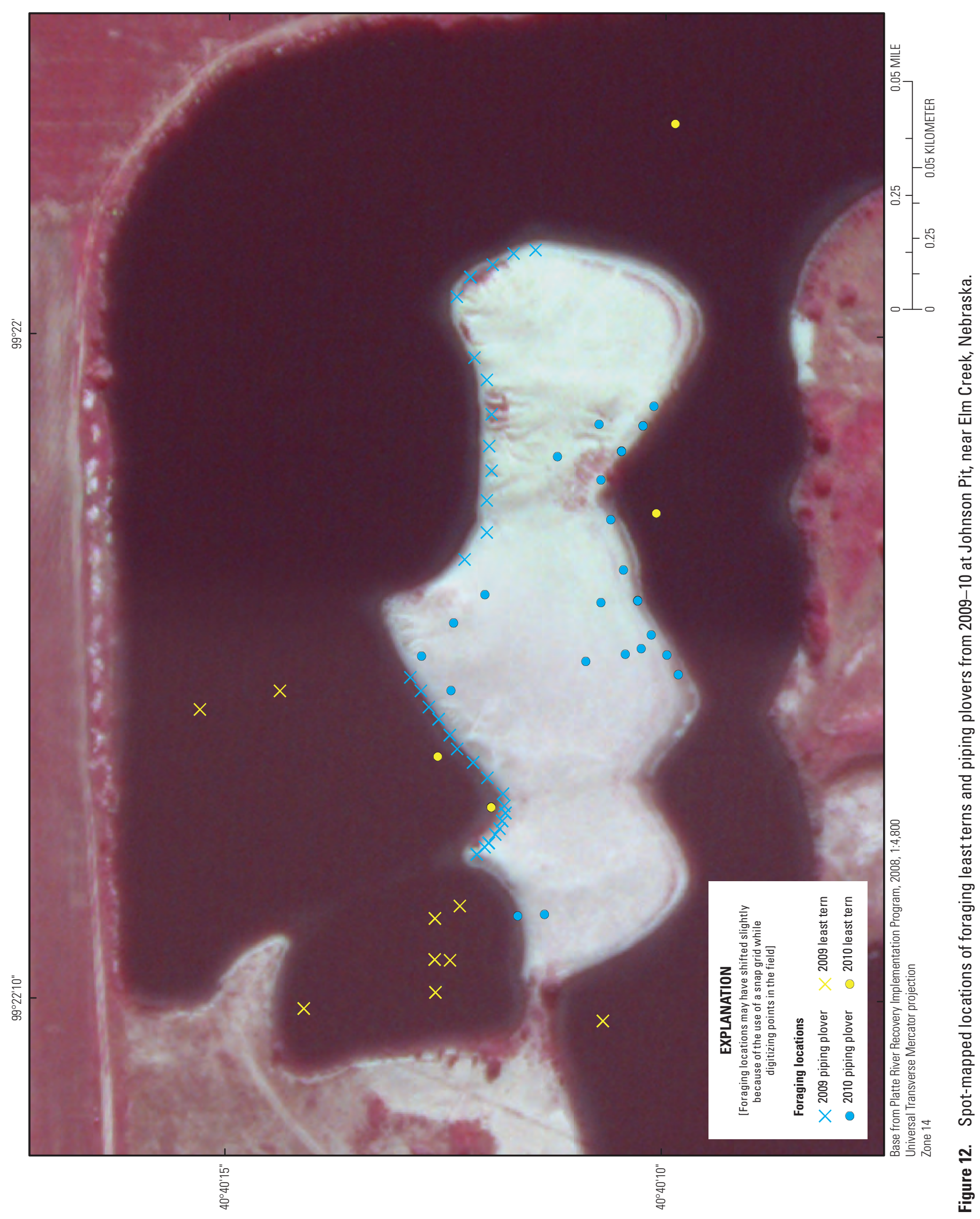




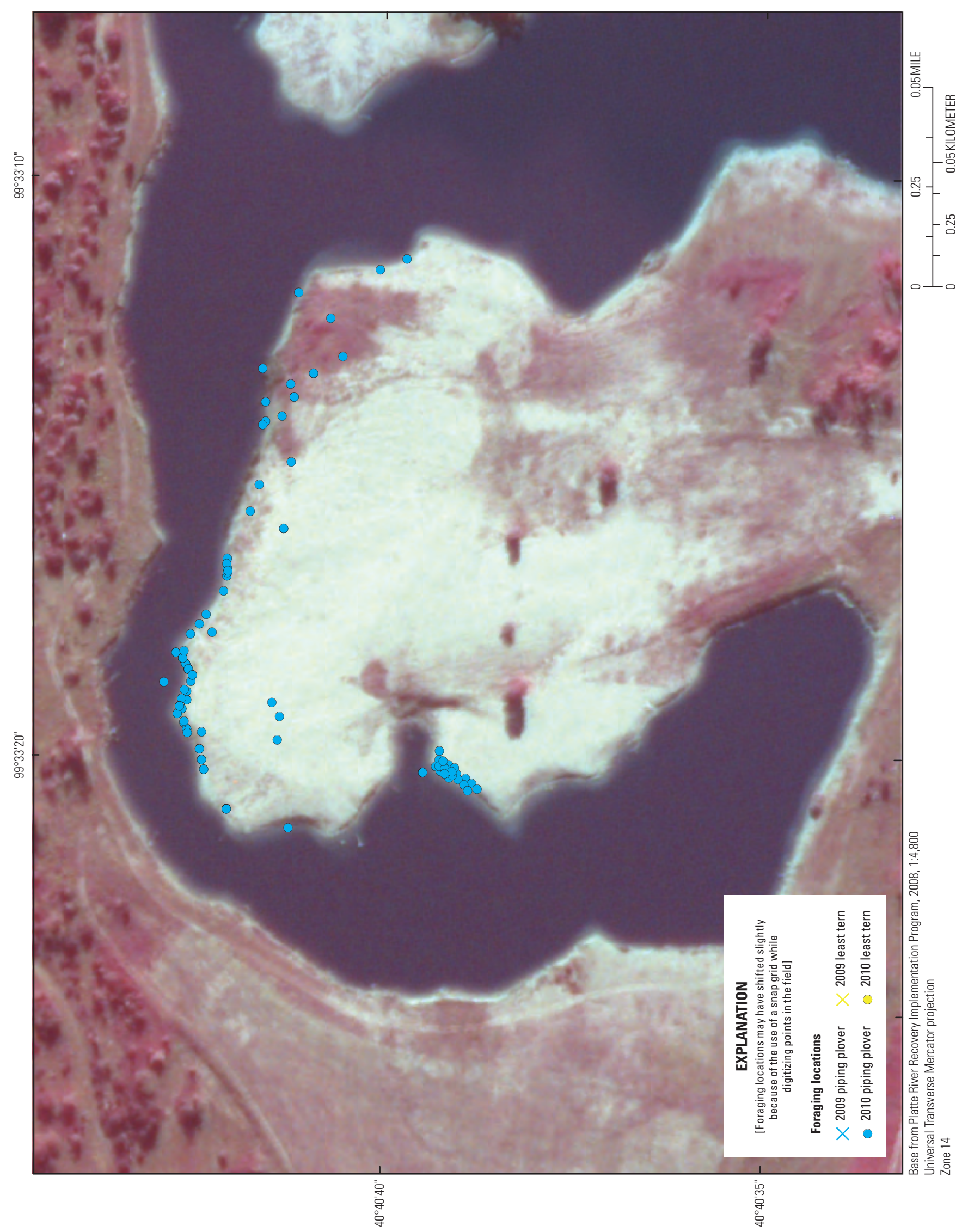

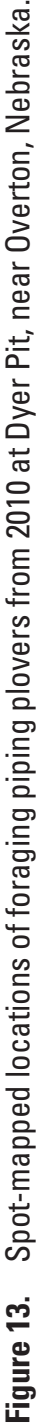




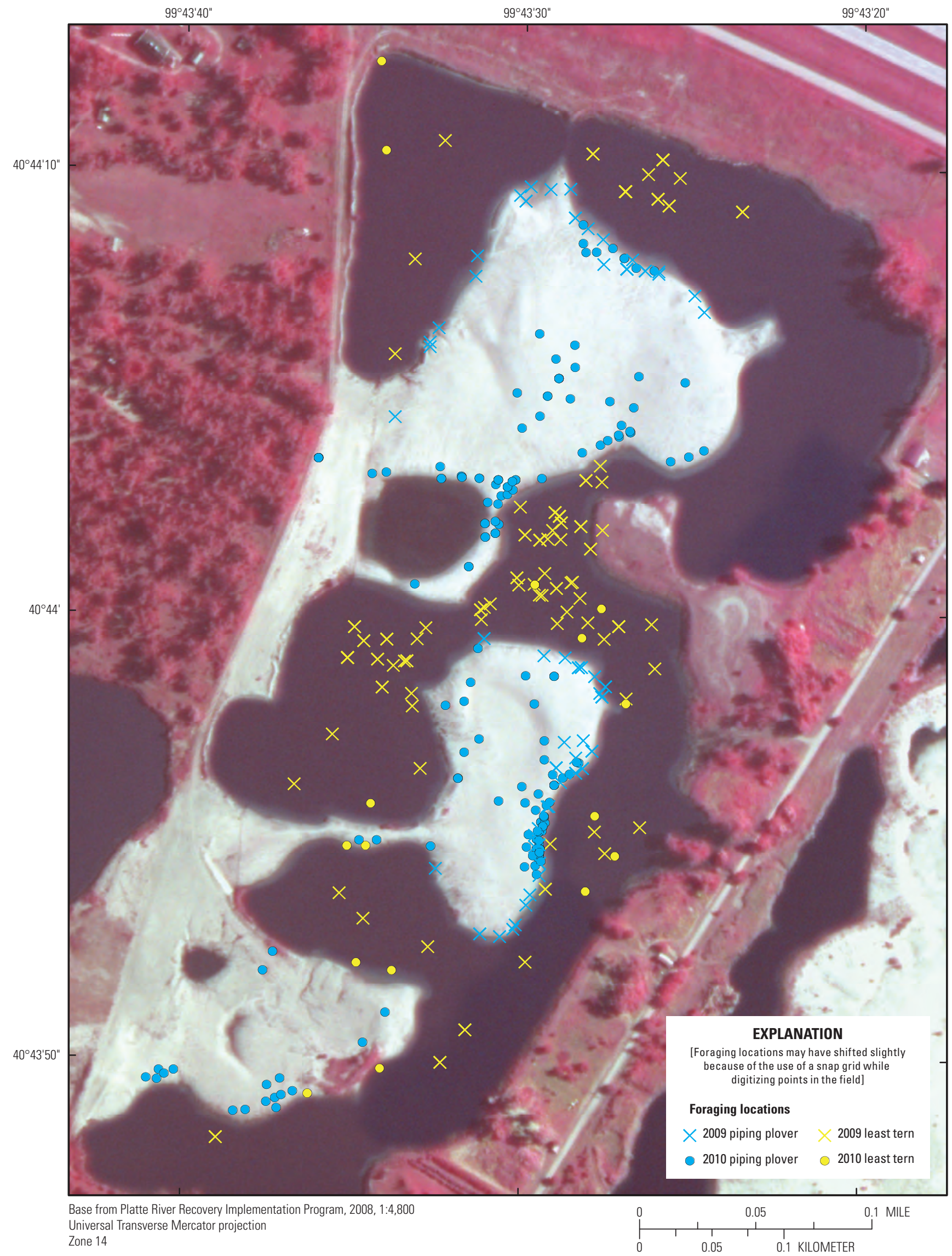

Figure 14. Spot-mapped locations of foraging least terns and piping plovers from 2009-10 at Lexington Pit, near Lexington, Nebraska. 


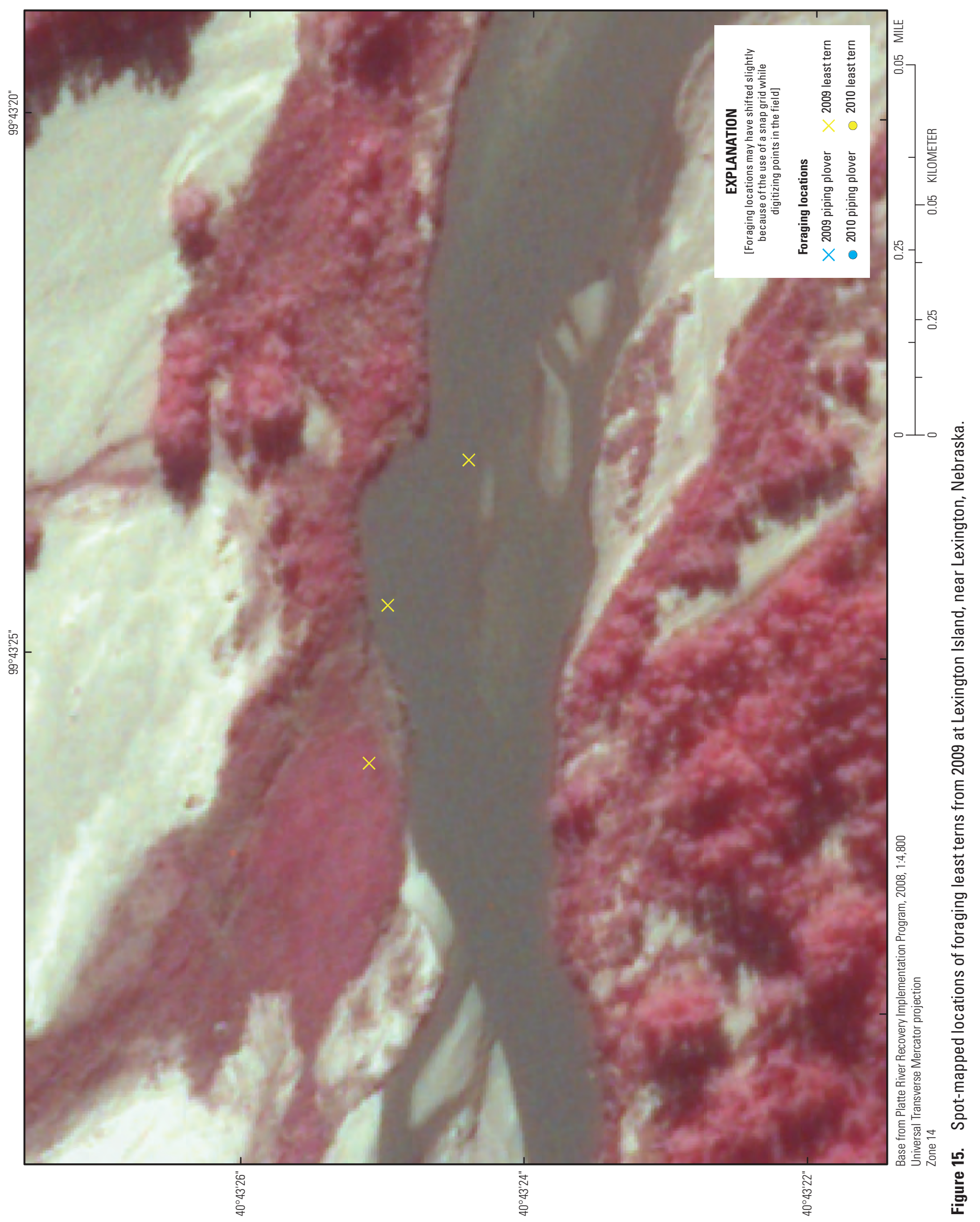




\section{Tables 14-22}




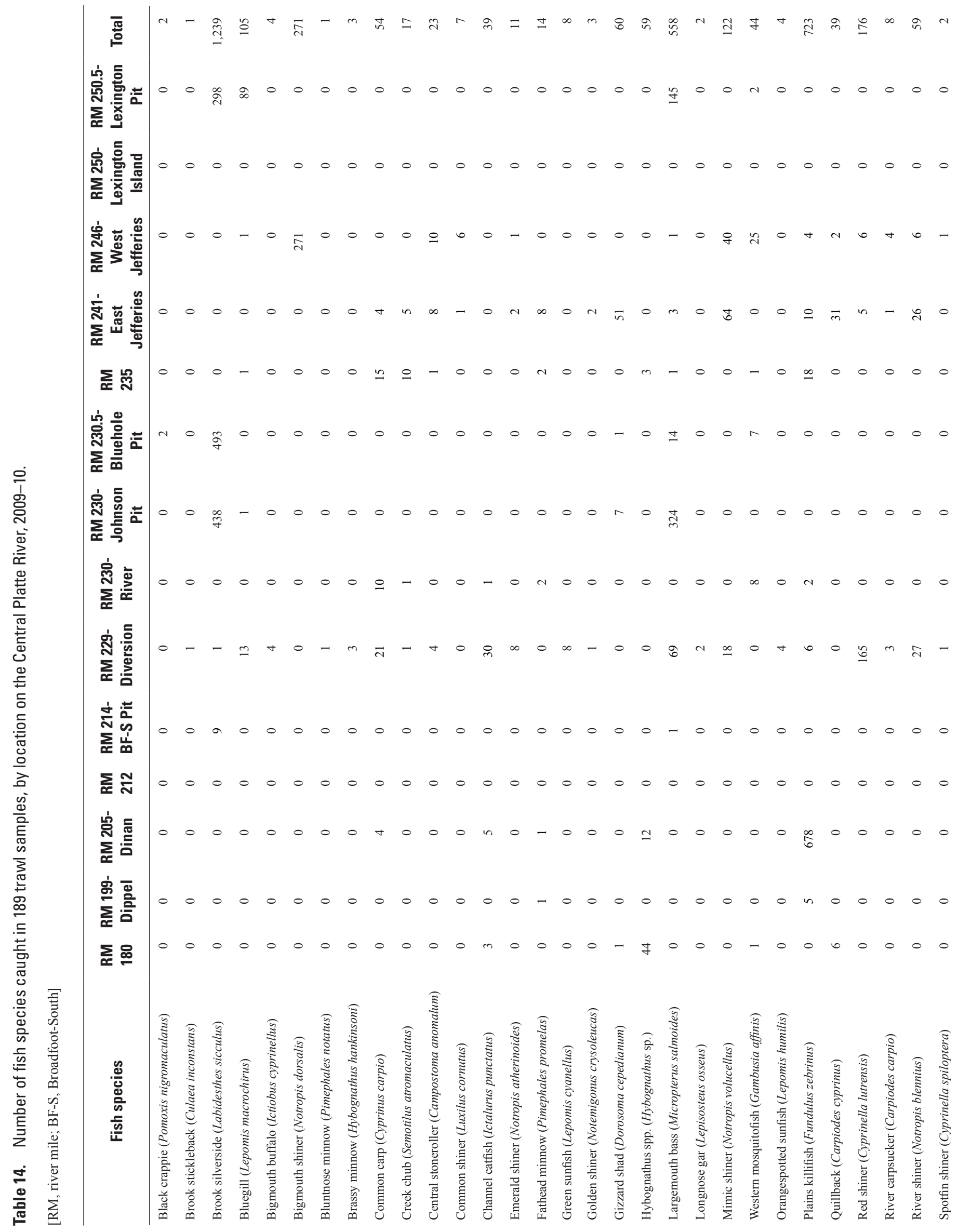




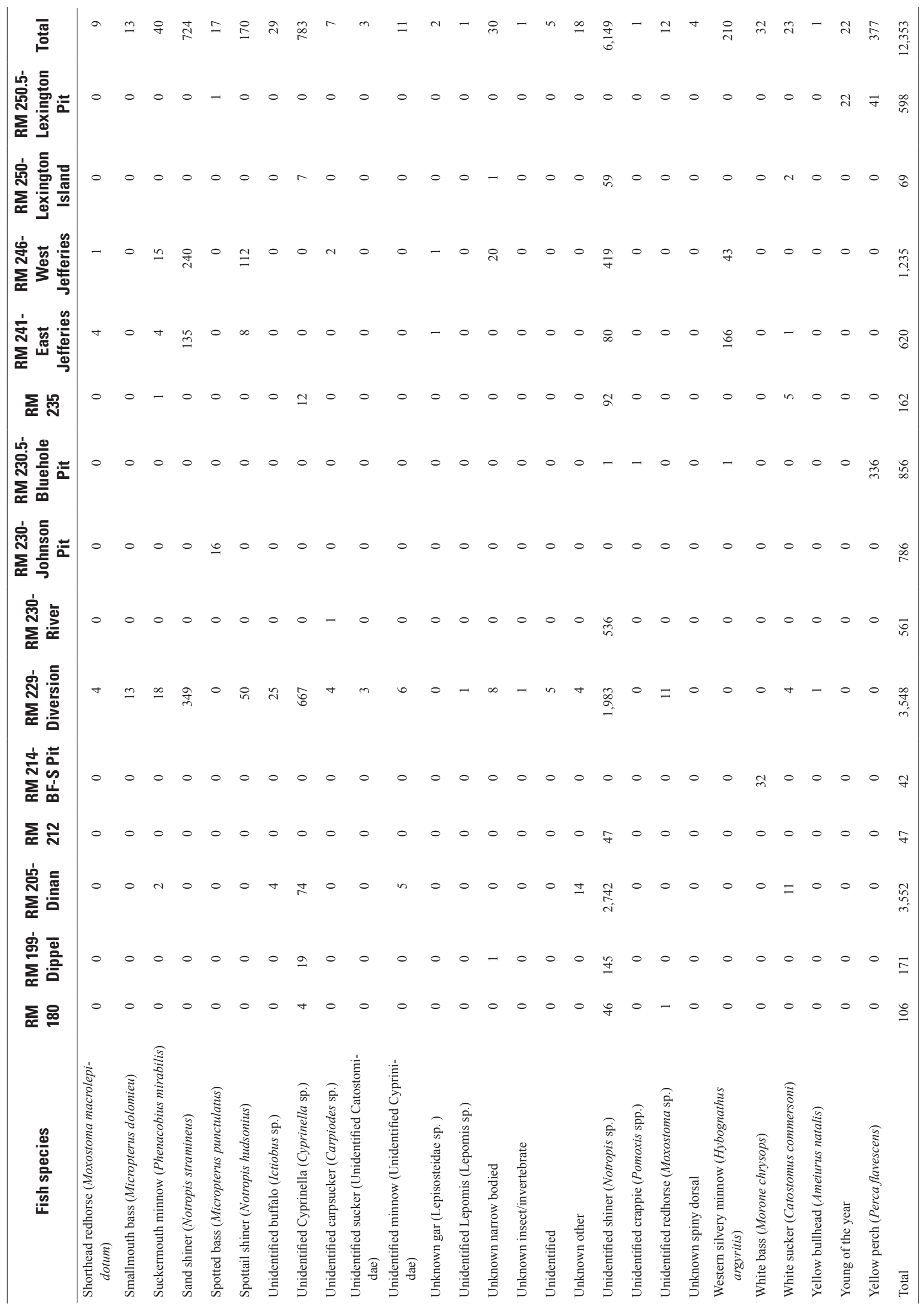


Table 15. Mean, lower 95-percent confidence limit and upper 95-percent confidence limit for habitat variables measured at least tern foraging locations and random points in sandpits on the Central Platte River, 2009-10.

[n, number; LCL, lower confidence level; UCL, upper confidence level; NTU, nephelometric turbidity units; ${ }^{\circ} \mathrm{C}$, degrees Celsius]

\begin{tabular}{|c|c|c|c|c|c|c|c|c|}
\hline & \multicolumn{4}{|c|}{ Foraging locations } & \multicolumn{4}{|c|}{ Random locations } \\
\hline & $\mathbf{n}$ & Mean & LCL & UCL & $\mathbf{n}$ & Mean & LCL & UCL \\
\hline Turbidity (NTU) & 22 & 5.4 & 3.6 & 7.2 & 44 & 5.5 & 4.2 & 6.8 \\
\hline Water temperature $\left({ }^{\circ} \mathrm{C}\right)$ & 22 & 24.4 & 21.9 & 26.8 & 44 & 24.4 & 22.7 & 26.1 \\
\hline
\end{tabular}

Table 16. Mean, lower 95-percent confidence limit and upper 95-percent confidence limit for habitat variables measured at least tern foraging locations and random points at river sites on the Central Platte River, 2009-10.

[n, number; LCL, lower confidence level; UCL, upper confidence level; NTU, nephelometric turbidity units; ${ }^{\circ} \mathrm{C}$, degrees Celsius; $\mathrm{m} / \mathrm{s}$, meters per second]

\begin{tabular}{|c|c|c|c|c|c|c|c|c|}
\hline & \multicolumn{4}{|c|}{ Foraging locations } & \multicolumn{4}{|c|}{ Random locations } \\
\hline & $\mathrm{n}$ & Mean & LCL & UCL & $\mathbf{n}$ & Mean & LCL & UCL \\
\hline Turbidity (NTU) & 38 & 37.5 & 30.4 & 44.6 & 86 & 33.4 & 29.5 & 37.3 \\
\hline Water temperature $\left({ }^{\circ} \mathrm{C}\right)$ & 38 & 24.4 & 22.9 & 25.9 & 86 & 25.3 & 24.3 & 26.2 \\
\hline Water velocity $(\mathrm{m} / \mathrm{s})$ & 38 & .5 & .4 & .6 & 86 & .5 & .4 & .6 \\
\hline
\end{tabular}

Table 17. Number of large (greater than 3 millimeters) and small (less than 3 millimeters) invertebrates caught on sticky traps during 33 sampling sessions on the Central Platte River, 2009-10.

[Each session consisted of one sample at a piping plover foraging site and two samples at random points. Numbers are raw counts of invertebrates that are uncorrected for differences in sampling area between vertical and horizontal sticks and length of sampling time. RM, river mile]

\begin{tabular}{lcrrrrrr}
\hline \multirow{2}{*}{$\begin{array}{c}\text { Location } \\
\text { (fig. 1) }\end{array}$} & & \multicolumn{2}{c}{ Foraging sites } & & \multicolumn{2}{c}{ Random points } \\
\cline { 7 - 8 } \cline { 7 - 8 } & Sessions & Large & Small & & Large & Small \\
\hline RM 205-Dinan Tract & 2 & 13 & 24 & & 10 & 18 \\
RM 230-Johnson Pit & 3 & 51 & 326 & & 34 & 850 \\
RM 230.5-Bluehole Pit & 13 & 209 & 901 & & 194 & 2,161 \\
RM 240-Dyer Pit & 2 & 28 & 26 & & 36 & 24 \\
RM 250.5-Lexington Pit & 13 & 120 & 246 & & 168 & 630 \\
Total & 33 & 421 & 1,523 & & 442 & 3,683 \\
\hline
\end{tabular}


Table 18. Mean, lower 95-percent confidence limit, and upper 95-percent confidence limit for habitat variables measured at piping plover foraging locations and random points on the Central Platte River, 2009-10.

[LCL, lower confidence limit; UCL, upper confidence limit]

\begin{tabular}{lrrrrrrrr}
\hline & \multicolumn{3}{c}{ Foraging locations } & & \multicolumn{3}{c}{ Random points } \\
\cline { 2 - 4 } \cline { 7 - 9 } & Mean & \multicolumn{1}{c}{ LCL } & UCL & & Mean & LCL & UCL \\
\hline Gravel & 2.0 & 0.1 & 3.9 & & 1.7 & 0.5 & 2.9 \\
Leaf litter & 0.5 & .1 & .9 & & 0.8 & .0 & 1.6 \\
Pebble & 14.6 & 4.9 & 24.3 & & 20.9 & 12.9 & 29.0 \\
Sand & 59.1 & 46.4 & 71.8 & & 59.0 & 50.3 & 67.7 \\
Silt & 5.2 & -1.7 & 12.1 & & 3.1 & -0.4 & 6.5 \\
Terrestrial vegetation & .6 & .2 & 1.0 & & 1.1 & .6 & 1.6 \\
Wetland vegetation & .2 & -.1 & 0.4 & & .3 & 0 & .7 \\
Woody vegetation & .2 & -.1 & .4 & & 0.1 & 0 & .2 \\
Wrack & 2.9 & -1.0 & 6.9 & & 1.3 & .2 & 2.3 \\
\hline
\end{tabular}

Table 19. Number and fate of least tern nests monitored on the Central Platte River, 2009-10.

$[\mathrm{RM}$, river mile]

\begin{tabular}{lcccccr}
\hline \multicolumn{1}{c}{$\begin{array}{c}\text { Site } \\
\text { (fig. 1) }\end{array}$} & Successful & $\begin{array}{c}\text { Probable } \\
\text { successful }\end{array}$ & Failed & $\begin{array}{c}\text { Probable } \\
\text { failure }\end{array}$ & Unknown & Total \\
\hline RM 199-Dippel Tract & 0 & 0 & 2 & 0 & 0 & 2 \\
RM 205-Dinan Tract & 1 & 0 & 0 & 0 & 0 & 1 \\
RM 214-Broadfoot-South Pit & 2 & 0 & 1 & 0 & 0 & 3 \\
RM 230-Johnson Pit & 2 & 0 & 4 & 0 & 4 & 10 \\
RM 230.5-Bluehole Pit & 19 & 4 & 12 & 1 & 7 & 43 \\
RM 240-Dyer Pit & 0 & 0 & 0 & 0 & 0 & 0 \\
RM 250.5-Lexington Pit & 15 & 7 & 8 & 0 & 9 & 39 \\
Total & 39 & 11 & 27 & 1 & 20 & 98 \\
\hline
\end{tabular}

Table 20. Number and fate of piping plover nests monitored on the Central Platte River, 2009-10.

[RM, river mile]

\begin{tabular}{lcccccc}
\hline \multicolumn{1}{c}{$\begin{array}{c}\text { Site } \\
\text { (fig. 1) }\end{array}$} & Successful & $\begin{array}{c}\text { Probable } \\
\text { successful }\end{array}$ & Failed & $\begin{array}{c}\text { Probable } \\
\text { failure }\end{array}$ & Unknown & Total \\
\hline RM 199-Dippel Tract & 1 & 1 & 3 & 0 & 0 & 5 \\
RM 205-Dinan Tract & 0 & 0 & 2 & 0 & 1 & 3 \\
RM 214-Broadfoot-South Pit & 0 & 2 & 0 & 0 & 0 & 2 \\
RM 230-Johnson Pit & 1 & 1 & 1 & 0 & 2 & 5 \\
RM 230.5-Bluehole Pit & 5 & 2 & 3 & 0 & 2 & 12 \\
RM 240-Dyer Pit & 1 & 0 & 0 & 0 & 0 & 1 \\
RM 250.5-Lexington Pit & 2 & 1 & 5 & 0 & 3 & 11 \\
Total & 10 & 7 & 14 & 0 & 8 & 39 \\
\hline
\end{tabular}


Table 21. Banding and marking records for least tern and piping plover adults on the Central Platte River, 2009-10.

[Band combinations are reported by leg position (left leg top, left leg bottom: right leg top, right leg bottom), with each leg position including up to two bands. Examples: YF is yellow flag; V/W is violet over white split band. LETE, least tern; -, no band; t, radio transmitter; Y, yellow; /, split band; V, violet; $\mathrm{R}$, red; O, orange; G, green (kelly); L, pastel blue or light blue; C, cobalt blue or bright blue; K, black; W, white; PIPL, piping plover; X, metal; NT, no transmitter; P, pink; D, dark green (not used)]

\begin{tabular}{|c|c|c|c|c|c|c|}
\hline Band number & Date banded & Species & River mile & Nest number & Color band combination & Transmitter frequency \\
\hline 2211-29913 & $6 / 18 / 2009$ & LETE & 250.5 & 106 & - T, - Y/V : - -, R R & 169.180 \\
\hline 2211-29915 & $6 / 18 / 2009$ & LETE & 250.5 & 108 & - T, - Y/V : - -, Y R & 169.207 \\
\hline 2211-29921 & $6 / 18 / 2009$ & LETE & 250.5 & 117 & - T, - Y/V : - -, O R & 169.295 \\
\hline 2211-29922 & $6 / 19 / 2009$ & LETE & 250.5 & 109 & - T, - Y/V : - -, G R & 169.309 \\
\hline 2211-29923 & $6 / 19 / 2009$ & LETE & 230.5 & 212 & - T, - Y/V : - -, L R & 169.321 \\
\hline 2211-29924 & $6 / 19 / 2009$ & LETE & 230.5 & 210 & $-\mathrm{T},-\mathrm{Y} / \mathrm{V}:--, \mathrm{C} \mathrm{R}$ & 169.333 \\
\hline $2211-29926$ & $6 / 23 / 2009$ & LETE & 250.5 & 114 & - V, - R : - T, - V/K & 169.357 \\
\hline 2211-29927 & $6 / 23 / 2009$ & LETE & 250.5 & 110 & $-\mathrm{V},-\mathrm{O}:-\mathrm{T},-\mathrm{V} / \mathrm{K}$ & 169.370 \\
\hline 2211-29928 & $6 / 25 / 2009$ & LETE & 250.5 & 116 & $-\mathrm{T},-\mathrm{Y} / \mathrm{V}:--, \mathrm{L} \mathrm{O}$ & 169.382 \\
\hline 2211-29946 & $6 / 25 / 2009$ & LETE & 250.5 & 119 & - T, - Y/V : - -, G O & 169.621 \\
\hline 2211-29992 & $6 / 25 / 2009$ & LETE & 230.5 & 216 & - T, - Y/V : - -, Y O & 170.358 \\
\hline 2211-29997 & $6 / 25 / 2009$ & LETE & 230 & 305 & - T, - Y/V : - -, O O & 170.443 \\
\hline 2211-29999 & $6 / 25 / 2009$ & LETE & 230 & 306 & - T, - Y/V : - -, R O & 170.472 \\
\hline $2211-29930$ & $6 / 30 / 2009$ & LETE & 230.5 & 220 & - T, - Y/V : - -, W R & 169.408 \\
\hline 2211-29939 & $6 / 30 / 2009$ & LETE & 230.5 & 222 & - T, - Y/V : - -, V R & 169.522 \\
\hline 2211-29941 & $6 / 30 / 2009$ & LETE & 230.5 & 218 & - T, - Y/V : - -, K R & 169.558 \\
\hline $0861-43443$ & $6 / 15 / 2010$ & LETE & 250.5 & 109 &,-- C W : - T, V V & 169.347 \\
\hline 0861-53446 & $6 / 16 / 2010$ & LETE & 250.5 & 105 & - -, O W : - T, V V & 169.507 \\
\hline $0861-53445$ & $6 / 16 / 2010$ & LETE & 250.5 & 115 &,-- G W : - T, V V & 169.395 \\
\hline 0861-53444 & $6 / 16 / 2010$ & LETE & 250.5 & 113 &,-- R W : - T, V V & 169.383 \\
\hline 0861-53447 & $6 / 17 / 2010$ & LETE & 230.5 & 212 & - -, V W : - T, V V & 169.535 \\
\hline $0861-53448$ & $7 / 7 / 2010$ & LETE & 230.5 & 224 &,-- K W : - T, V V & 169.571 \\
\hline $0861-53450$ & $7 / 19 / 2010$ & LETE & 250.5 & 125 & - -, Y W : - T, V V & 169.658 \\
\hline $2301-46480$ & $5 / 21 / 2009$ & PIPL & 230.5 & 200 & - LF, Y Y : - X, R R & NT \\
\hline $2301-46491$ & $5 / 21 / 2009$ & PIPL & 250.5 & 100 & - LF, Y Y : - X, R Y & NT \\
\hline $2301-46484$ & $5 / 22 / 2009$ & PIPL & 230 & 300 & - LF, Y Y : - X, R K & NT \\
\hline $2301-46496$ & $5 / 22 / 2009$ & PIPL & 230 & 301 & - LF, Y Y : - X, R G & NT \\
\hline $2301-46473$ & $6 / 1 / 2009$ & PIPL & 205 & 400 & - LF, G V/P : - X, R C & 169.132 \\
\hline $2301-46474$ & $6 / 1 / 2009$ & PIPL & 230.5 & 202 & - LF, G V/P : - X, R G & 169.008 \\
\hline $2301-46475$ & $6 / 1 / 2009$ & PIPL & 230.5 & 203 & - LF, G V/P : - X, R R & NT \\
\hline $2301-46487$ & $6 / 1 / 2009$ & PIPL & 250.5 & 105 & - LF, G V/P : - X, R K & 169.106 \\
\hline $2301-46489$ & $6 / 1 / 2009$ & PIPL & 250.5 & 102 & - LF, G V/P : - X, R O & 169.068 \\
\hline $2301-46472$ & $6 / 8 / 2009$ & PIPL & 230.5 & 203 & - LF, G V/P : - X, C O & 169.155 \\
\hline $2301-46470$ & $6 / 12 / 2009$ & PIPL & 250.5 & 111 & - LF, G V/P : - X, G G & 169.220 \\
\hline 1991-92196 & $5 / 13 / 2010$ & PIPL & 250.5 & 101 & - X, K/W C : - LF, C C & 170.444 \\
\hline $2301-46475$ & $5 / 15 / 2010$ & PIPL & 230.5 & 204 & - LF, K/W G : - X, R R & 169.857 \\
\hline 1991-92198 & $5 / 15 / 2010$ & PIPL & 250.5 & 102 & - X, K/W R : - LF, C C & 170.405 \\
\hline No band & $5 / 15 / 2010$ & PIPL & 205 & 602 &,-- K/W G : - LF, C C & 169.845 \\
\hline 1991-92199 & $5 / 17 / 2010$ & PIPL & 230.5 & 202 & - X, K/W Y : - LF, C C & 169.757 \\
\hline
\end{tabular}


Table 21. Banding and marking records for least tern and piping plover adults on the Central Platte River, 2009-10._Continued

[Band combinations are reported by leg position (left leg top, left leg bottom: right leg top, right leg bottom), with each leg position including up to two bands. Examples: YF is yellow flag; V/W is violet over white split band. LETE, least tern; -, no band; t, radio transmitter; Y, yellow; /, split band; V, violet; $\mathrm{R}$, red; O, orange; G, green (kelly); L, pastel blue or light blue; C, cobalt blue or bright blue; K, black; W, white; PIPL, piping plover; X, metal; NT, no transmitter; P, pink; D, dark green (not used)]

\begin{tabular}{ccccccc}
\hline Band number & Date banded & Species & River mile & Nest number & Color band combination & Transmitter frequency \\
\hline $2301-46459$ & $5 / 26 / 2010$ & PIPL & 214 & 502 & - X, K/W L : - LF, R K & 169.708 \\
$2301-46460$ & $5 / 26 / 2010$ & PIPL & 214 & 501 & - X, K/W Y : - LF, R K & 169.730 \\
$2211-29694$ & $6 / 1 / 2010$ & PIPL & 230.5 & 205 & - X, K/W K : - LF, R K & 169.370 \\
$2211-29683$ & $6 / 5 / 2010$ & PIPL & 230 & 302 & - X, K/W R : - LF, R K & 169.131 \\
$2211-29682$ & $6 / 5 / 2010$ & PIPL & 230.5 & 207 & - X, K/W G : - LF, R K & 169.309 \\
$2211-29684$ & $6 / 9 / 2010$ & PIPL & 199 & 603 & - X, K/W Y : - LF, R O & 169.119 \\
$2211-29685$ & $6 / 11 / 2010$ & PIPL & 230 & 303 & - X, K/W O : - LF, R O & 169.321 \\
$2211-29688$ & $7 / 7 / 2010$ & PIPL & 240 & 401 & - X, K/W K : - LF, R G & 169.745 \\
\hline
\end{tabular}


Table 22. Banding and marking records for least tern and piping plover chicks on the Central Platte River, $2009-10$.

[Band combinations are reported by leg position (left leg top, left leg bottom : right leg top, right leg bottom), with each leg position including up to two bands. Examples: YF is yellow flag; V/W is violet over white split band. LETE, least tern; -, no band; X, metal; UNK, unknown; L= pastel blue or light blue; V, violet; /, split band; K, black; O, orange; W, white; C, cobalt blue or bright blue; G, green (kelly); R, red; Y, yellow; PIPL, piping plover; F, flag; P, pink; D, dark green (not used)]

\begin{tabular}{|c|c|c|c|c|c|}
\hline Band number & Date banded & Species & River mile & Nest number & Color band combination \\
\hline $1981-27636$ & $06 / 16 / 09$ & LETE & 230.5 & 204 &,$----:--,-X$ \\
\hline $1981-27634$ & $06 / 16 / 09$ & LETE & 230.5 & 204 &,$----:--,-X$ \\
\hline $1981-27661$ & 06/26/09 & LETE & 230 & UNK & - L, - V : - V/K, - X \\
\hline $1981-27654$ & $06 / 26 / 09$ & LETE & 230 & UNK & - L, - K : - V/K, - X \\
\hline $1981-27623$ & 06/26/09 & LETE & 230.5 & UNK & $-\mathrm{V},-\mathrm{W}:-\mathrm{V} / \mathrm{K},-\mathrm{X}$ \\
\hline $1981-27656$ & $06 / 26 / 09$ & LETE & 230.5 & 213 & - L, - L : - V/K, - X \\
\hline $1981-27662$ & $06 / 26 / 09$ & LETE & 230.5 & 213 & $-\mathrm{L},-\mathrm{C}:-\mathrm{V} / \mathrm{K},-\mathrm{X}$ \\
\hline $1981-27684$ & 06/26/09 & LETE & 250.5 & UNK & $-\mathrm{V},-\mathrm{G}:-\mathrm{V} / \mathrm{K},-\mathrm{X}$ \\
\hline $1981-27618$ & $06 / 26 / 09$ & LETE & 250.5 & 113 & $-\mathrm{V},-\mathrm{K}:-\mathrm{K} / \mathrm{V},-\mathrm{X}$ \\
\hline $1981-27675$ & 06/26/09 & LETE & 250.5 & UNK & - L, - R : - V/K, - X \\
\hline $1981-27684$ & 06/25/09 & LETE & 250.5 & UNK & $-\mathrm{V},-\mathrm{G}:-\mathrm{V} / \mathrm{K},-\mathrm{X}$ \\
\hline $1981-22000$ & 06/28/09 & LETE & 250.5 & 117 &,$----:--,-X$ \\
\hline 1981-21992 & $06 / 28 / 09$ & LETE & 250.5 & 117 &,$----:--,-X$ \\
\hline $1981-21990$ & 07/01/09 & LETE & 250.5 & 119 & $-\mathrm{L},-\mathrm{W}:-\mathrm{V} / \mathrm{K},-\mathrm{X}$ \\
\hline $1981-27625$ & 07/08/09 & LETE & 230.5 & 216 & $-\mathrm{C},-\mathrm{W}:-\mathrm{V} / \mathrm{K},-\mathrm{X}$ \\
\hline 1981-21987 & 07/14/09 & LETE & 250.5 & UNK & $--, \mathrm{C} K:--, \mathrm{V} / \mathrm{K} \mathrm{X}$ \\
\hline $1981-21993$ & 07/14/09 & LETE & 250.5 & UNK & $--, \mathrm{W} \mathrm{W}:--, \mathrm{V} / \mathrm{K} \mathrm{X}$ \\
\hline $1981-21997$ & 07/15/09 & LETE & 230.5 & UNK & $-\mathrm{W},-\mathrm{K}:-\mathrm{V} / \mathrm{K},-\mathrm{X}$ \\
\hline 1981-21989 & 07/17/09 & LETE & 230.5 & UNK & $-\mathrm{W},-\mathrm{V}:-\mathrm{V} / \mathrm{K},-\mathrm{X}$ \\
\hline $1981-21984$ & 07/17/09 & LETE & 230.5 & UNK & $-\mathrm{W},-\mathrm{C}:-\mathrm{V} / \mathrm{K},-\mathrm{X}$ \\
\hline $1981-27535$ & 07/17/09 & LETE & 230.5 & UNK & - W, - L : - V/K, - X \\
\hline $1981-27655$ & 07/21/09 & LETE & 205 & 403 & $-\mathrm{W},-\mathrm{G}:-\mathrm{V} / \mathrm{K},-\mathrm{X}$ \\
\hline $1981-27659$ & 07/21/09 & LETE & 205 & 403 & $-\mathrm{W},-\mathrm{O}:-\mathrm{V} / \mathrm{K},-\mathrm{X}$ \\
\hline $1981-21995$ & 07/23/09 & LETE & 230.5 & UNK & - -, W R : - V/K, - X \\
\hline 1981-21991 & 07/23/09 & LETE & 230.5 & 226 & $-\mathrm{K} / \mathrm{V},-\mathrm{W}:-\mathrm{W},-\mathrm{X}$ \\
\hline $1981-36333$ & 07/23/09 & LETE & 230.5 & UNK & $-\mathrm{K} / \mathrm{V},-\mathrm{K}:-\mathrm{W},-\mathrm{X}$ \\
\hline $1981-36332$ & 07/23/09 & LETE & 230.5 & UNK & $-\mathrm{K} / \mathrm{V},-\mathrm{V}:-\mathrm{W},-\mathrm{X}$ \\
\hline $1981-27625$ & $07 / 22 / 09$ & LETE & 230.5 & 216 & $--, C W:-V / K,-X$ \\
\hline
\end{tabular}


Table 22. Banding and marking records for least tern and piping plover chicks on the Central Platte River, 2009-10._Continued

[Band combinations are reported by leg position (left leg top, left leg bottom : right leg top, right leg bottom), with each leg position including up to two bands. Examples: YF is yellow flag; V/W is violet over white split band. LETE, least tern; -, no band; X, metal; UNK, unknown; L= pastel blue or light blue; V, violet; /, split band; K, black; O, orange; W, white; C, cobalt blue or bright blue; G, green (kelly); R, red; Y, yellow; PIPL, piping plover; F, flag; P, pink; D, dark green (not used)]

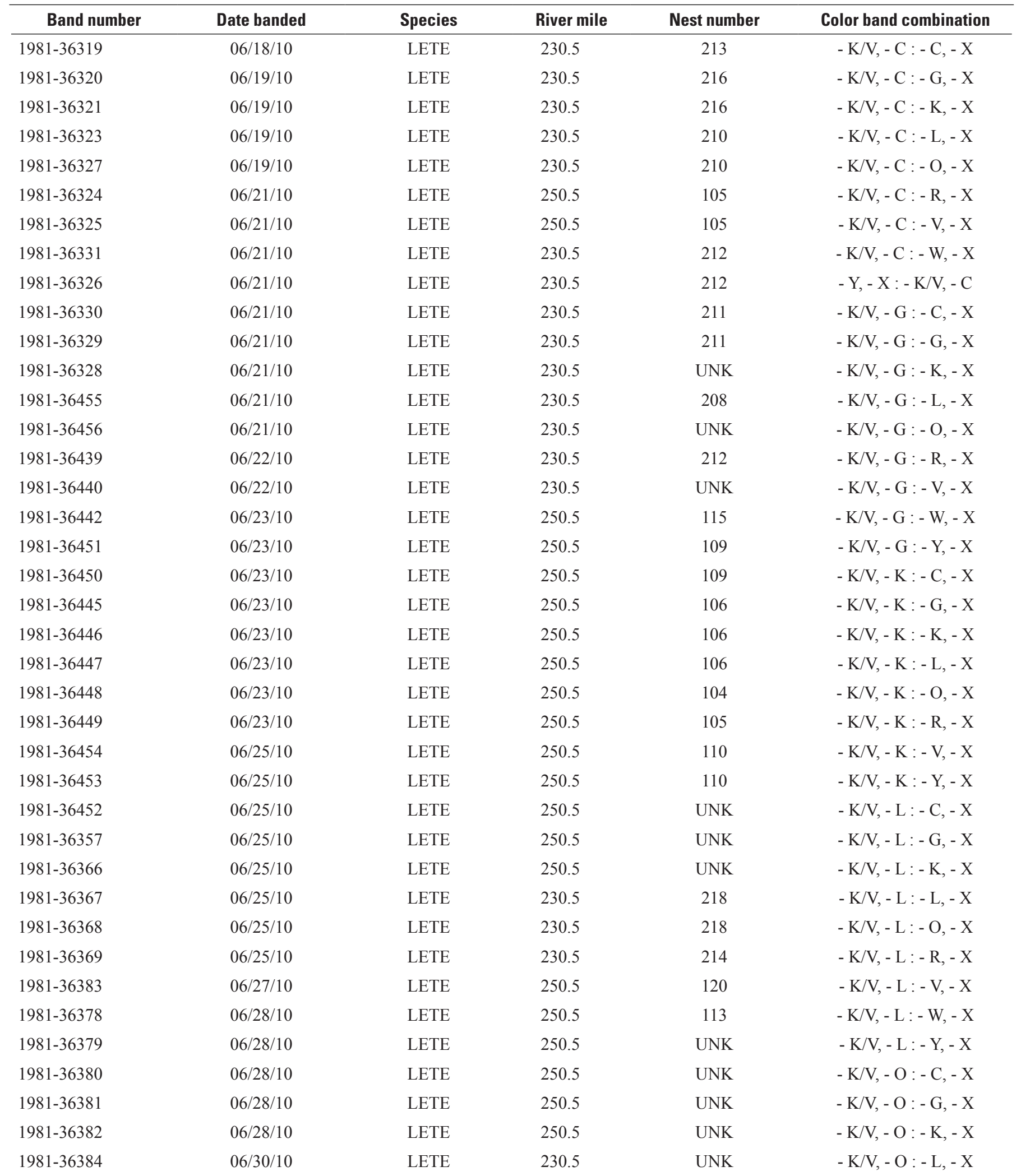


Table 22. Banding and marking records for least tern and piping plover chicks on the Central Platte River, 2009-10.-Continued

[Band combinations are reported by leg position (left leg top, left leg bottom : right leg top, right leg bottom), with each leg position including up to two bands. Examples: YF is yellow flag; V/W is violet over white split band. LETE, least tern; -, no band; X, metal; UNK, unknown; L= pastel blue or light blue; V, violet; /, split band; K, black; O, orange; W, white; C, cobalt blue or bright blue; G, green (kelly); R, red; Y, yellow; PIPL, piping plover; F, flag; P, pink; D, dark green (not used)]

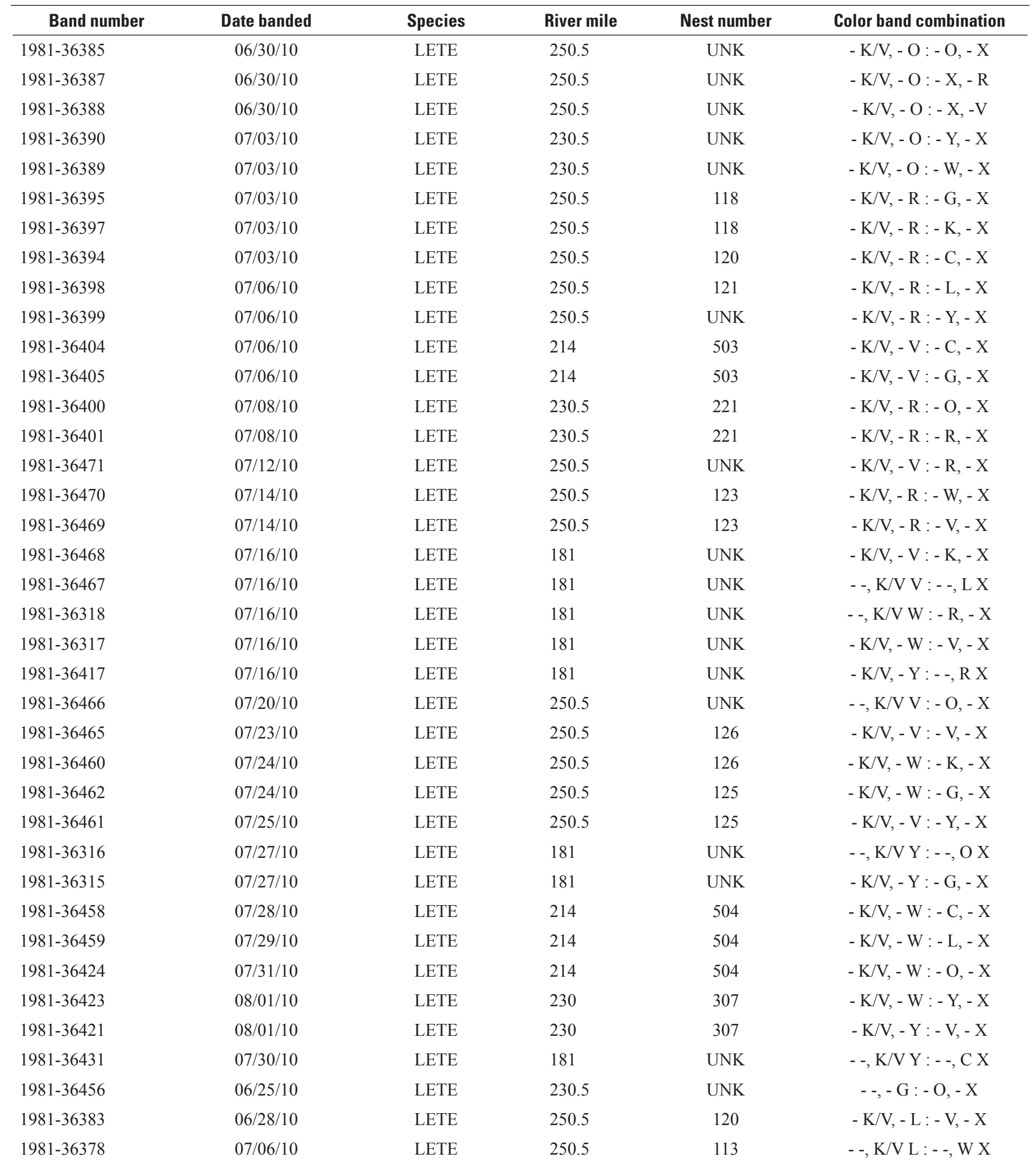


Table 22. Banding and marking records for least tern and piping plover chicks on the Central Platte River, 2009-10.-Continued

[Band combinations are reported by leg position (left leg top, left leg bottom : right leg top, right leg bottom), with each leg position including up to two bands. Examples: YF is yellow flag; V/W is violet over white split band. LETE, least tern; -, no band; X, metal; UNK, unknown; L= pastel blue or light blue; V, violet; I, split band; K, black; O, orange; W, white; C, cobalt blue or bright blue; G, green (kelly); R, red; Y, yellow; PIPL, piping plover; F, flag; P, pink; D, dark green (not used)]

\begin{tabular}{|c|c|c|c|c|c|}
\hline Band number & Date banded & Species & River mile & Nest number & Color band combination \\
\hline $1981-36455$ & $07 / 06 / 10$ & LETE & 230.5 & 208 &,$-- \mathrm{K} / \mathrm{V}$ G : - -, L X \\
\hline $1981-36440$ & $07 / 09 / 10$ & LETE & 230.5 & UNK &,-- K/V G : - -, V X \\
\hline $1981-36383$ & $07 / 10 / 10$ & LETE & 250.5 & 120 & $--, \mathrm{K} / \mathrm{V} \mathrm{L}:-\mathrm{V},-\mathrm{X}$ \\
\hline $1981-36388$ & $07 / 10 / 10$ & LETE & 250.5 & UNK &,$-- \mathrm{K} / \mathrm{V}$ O : - X, -V \\
\hline 1981-36394 & $07 / 10 / 10$ & LETE & 250.5 & 120 & $--, \mathrm{K} / \mathrm{V} \mathrm{R}:-\mathrm{C},-\mathrm{X}$ \\
\hline $1981-36366$ & 07/10/10 & LETE & 250.5 & UNK & $--, \mathrm{K} / \mathrm{V} \mathrm{L}:--, \mathrm{K} \mathrm{X}$ \\
\hline $1981-36442$ & $07 / 10 / 10$ & LETE & 250.5 & 115 &,-- K/V G : - -, W X \\
\hline $1981-36454$ & $07 / 10 / 10$ & LETE & 250.5 & 110 & $--, \mathrm{K} / \mathrm{V} \mathrm{K}:--, \mathrm{V} X$ \\
\hline $1981-36387$ & $07 / 10 / 10$ & LETE & 250.5 & UNK & - -, K/V O : - X, - R \\
\hline $1981-36383$ & $07 / 12 / 10$ & LETE & 250.5 & 120 & $--, \mathrm{K} / \mathrm{V} \mathrm{L}:--, \mathrm{VX}$ \\
\hline $1981-36385$ & $07 / 12 / 10$ & LETE & 250.5 & UNK & - -, K/V O : - -, O X \\
\hline 1981-36394 & $07 / 12 / 10$ & LETE & 250.5 & 120 &,-- K/V R : - -, C X \\
\hline 1981-36399 & $07 / 12 / 10$ & LETE & 250.5 & UNK & - -, K/V R : - Y, - X \\
\hline 1981-36399 & $07 / 15 / 10$ & LETE & 250.5 & UNK &,-- K/V R : - -, Y X \\
\hline $1981-36466$ & $07 / 21 / 10$ & LETE & 250.5 & UNK & - -, K/V V : - -, O X \\
\hline $1981-36470$ & $07 / 27 / 10$ & LETE & 250.5 & 123 & - -, K/V R : - -, W X \\
\hline $1981-36327$ & $06 / 21 / 10$ & LETE & 230.5 & 210 & - K/V, - C : - O, - X \\
\hline $1981-36455$ & $06 / 22 / 10$ & LETE & 230.5 & 208 & $-\mathrm{K} / \mathrm{V},-\mathrm{G}:-\mathrm{L},-\mathrm{X}$ \\
\hline $1981-36455$ & $06 / 23 / 10$ & LETE & 230.5 & 208 & $-\mathrm{K} / \mathrm{V},-\mathrm{G}:-\mathrm{L},-\mathrm{X}$ \\
\hline $1981-36450$ & $06 / 25 / 10$ & LETE & 250.5 & 109 & $-\mathrm{K} / \mathrm{V},-\mathrm{K}:-\mathrm{C},-\mathrm{X}$ \\
\hline $1981-36451$ & $06 / 25 / 10$ & LETE & 250.5 & 109 & - K/V, - G : - Y, - X \\
\hline $1981-36461$ & $07 / 26 / 10$ & LETE & 250.5 & 125 & - K/V, -V : - Y, - X \\
\hline $1981-36460$ & $07 / 27 / 10$ & LETE & 250.5 & 126 & - K/V, - W : - K, - X \\
\hline $2301-46486$ & 05/30/09 & PIPL & 230.5 & 200 & - LF, R C : - X, Y Y \\
\hline $2301-46493$ & 05/30/09 & PIPL & 230.5 & 200 & - LF, K O : - X, Y Y \\
\hline $2301-46482$ & 06/03/09 & PIPL & 230 & 300 & - LF, K R : - X, Y Y \\
\hline $2301-46476$ & 06/03/09 & PIPL & 230 & 300 & - LF, K K : - X, Y Y \\
\hline $2301-46494$ & 06/03/09 & PIPL & 230 & 300 & - LF, K C : - X, Y Y \\
\hline $2301-46471$ & 06/05/09 & PIPL & 230 & 301 & - LF, G V/P : - X, G C \\
\hline $2301-46478$ & 06/05/09 & PIPL & 230 & 301 & - LF, G P/V : - X, R C \\
\hline $2301-46490$ & 06/01/09 & PIPL & 250.5 & 100 & - LF, O R : - X, Y Y \\
\hline $2301-46498$ & 06/01/09 & PIPL & 250.5 & 100 & - LF, O G : - X, Y Y \\
\hline $2301-46499$ & 06/01/09 & PIPL & 250.5 & 100 & - LF, O O : - X, Y Y \\
\hline $2301-46497$ & 06/01/09 & PIPL & 250.5 & 100 & - LF, O K : - X, Y Y \\
\hline $2301-46495$ & 06/08/09 & PIPL & 250.5 & 102 & - LF, G V/P : - X, C O \\
\hline $2301-46488$ & 06/08/09 & PIPL & 250.5 & 102 & - LF, G V/P : - X, C C \\
\hline $2301-46477$ & 06/16/09 & PIPL & 230.5 & UNK & - LF, G V/P : - X, K K \\
\hline $2301-46483$ & 06/16/09 & PIPL & 230.5 & UNK & - LF, G V/P : - X, K C \\
\hline
\end{tabular}


Table 22. Banding and marking records for least tern and piping plover chicks on the Central Platte River, 2009-10.-Continued

[Band combinations are reported by leg position (left leg top, left leg bottom : right leg top, right leg bottom), with each leg position including up to two bands. Examples: YF is yellow flag; V/W is violet over white split band. LETE, least tern; -, no band; X, metal; UNK, unknown; $\mathrm{L}=$ pastel blue or light blue; V, violet; /, split band; K, black; O, orange; W, white; C, cobalt blue or bright blue; G, green (kelly); R, red; Y, yellow; PIPL, piping plover; F, flag; P, pink; D, dark green (not used)]

\begin{tabular}{|c|c|c|c|c|c|}
\hline Band number & Date banded & Species & River mile & Nest number & Color band combination \\
\hline $2301-46479$ & $06 / 16 / 09$ & PIPL & 230.5 & UNK & - LF, G V/P : - X, G O \\
\hline $2301-46481$ & 06/16/09 & PIPL & 230.5 & UNK & - LF, G V/P : - X, G R \\
\hline $2301-46485$ & 06/16/09 & PIPL & 230.5 & 200 & - LF, G V/P : - X, G K \\
\hline $2301-46462$ & $06 / 22 / 09$ & PIPL & 205 & 400 & - LF, G R : - X, Y Y \\
\hline $2301-46463$ & 06/22/09 & PIPL & 205 & 400 & - LF, G G : - X, Y Y \\
\hline $2301-46464$ & 06/22/09 & PIPL & 205 & 400 & - LF, G O : - X, Y Y \\
\hline $2301-46468$ & 06/26/09 & PIPL & 250.5 & UNK & - LF, G K : - X, Y Y \\
\hline $2301-46451$ & $06 / 26 / 09$ & PIPL & 250.5 & UNK & - LF, G C : - X, Y Y \\
\hline $2301-46455$ & $06 / 26 / 09$ & PIPL & 250.5 & UNK & - LF, R R : - X, Y Y \\
\hline $2301-46469$ & 06/26/09 & PIPL & 230.5 & UNK & - LF, R G : - X, Y Y \\
\hline $2301-46401$ & $05 / 23 / 10$ & PIPL & 250.5 & 101 & - LF, C C : - X, K/W O \\
\hline $2301-46402$ & $05 / 23 / 10$ & PIPL & 250.5 & 101 & - X, K/W K : - LF, C C \\
\hline $2301-46403$ & $05 / 23 / 10$ & PIPL & 250.5 & 101 & - X, K/W L : - LF, C C \\
\hline $2301-46466$ & $05 / 25 / 10$ & PIPL & 250.5 & 101 & - X, K/W L : - LF, C C \\
\hline $2301-46465$ & $05 / 25 / 10$ & PIPL & 230.5 & 204 & - X, K/W C : - LF, C R \\
\hline $2301-46467$ & $05 / 25 / 10$ & PIPL & 230.5 & 204 & - X, K/W R : - LF, C R \\
\hline $2301-46404$ & $05 / 25 / 10$ & PIPL & 230.5 & 204 & - X, K/W G : - LF, C R \\
\hline $2301-46405$ & $05 / 25 / 10$ & PIPL & 230.5 & 204 & - X, K/W O : - LF, C R \\
\hline $2301-46466$ & $05 / 26 / 10$ & PIPL & 250.5 & 101 & - X, K/W L : - LF, C G \\
\hline $2301-46458$ & $05 / 31 / 10$ & PIPL & 250.5 & 102 & - X, K/W K : - LF, C R \\
\hline $2301-46457$ & $05 / 31 / 10$ & PIPL & 250.5 & 102 & - X, K/W Y : - LF, C R \\
\hline $2301-46456$ & $06 / 01 / 10$ & PIPL & 250.5 & 102 & - X, K/W L : - LF, C R \\
\hline $2301-46454$ & $06 / 01 / 10$ & PIPL & 250.5 & 102 & - X, K/W C : - LF, C G \\
\hline $2301-46406$ & $06 / 07 / 10$ & PIPL & 230.5 & UNK & - X, K/W R : - LF, C G \\
\hline $2301-46407$ & $06 / 07 / 10$ & PIPL & 230.5 & UNK & - X, K/W G : - LF, C G \\
\hline $2301-46408$ & $06 / 07 / 10$ & PIPL & 230.5 & UNK & - X, K/W O : - LF, C G \\
\hline $2301-46409$ & $06 / 07 / 10$ & PIPL & 230.5 & UNK & - X, K/W K : - LF, C G \\
\hline $2301-46410$ & $06 / 09 / 10$ & PIPL & 230.5 & UNK & - X, K/W Y : - LF, C G \\
\hline $2301-46411$ & $06 / 09 / 10$ & PIPL & 230.5 & UNK & - X, K/W C : - LF, C L \\
\hline $2301-46412$ & $06 / 09 / 10$ & PIPL & 230.5 & UNK & - X, K/W R : - LF, C L \\
\hline $2301-46413$ & $06 / 09 / 10$ & PIPL & 230.5 & UNK & - X, K/W G : - LF, C L \\
\hline $2301-46453$ & $06 / 11 / 10$ & PIPL & 214 & UNK & - X, K/W O : - LF, C L \\
\hline $2301-46415$ & $06 / 10 / 10$ & PIPL & 214 & UNK & - X, K/W K : - LF, C L \\
\hline $2301-46452$ & $06 / 10 / 10$ & PIPL & 214 & UNK & - X, K/W L : - LF, C L \\
\hline $2211-29687$ & $06 / 17 / 10$ & PIPL & 230.5 & 206 & - X, K/W K : - LF, C O \\
\hline $2211-29692$ & $06 / 17 / 10$ & PIPL & 199 & 603 & - X, K/W C : - LF, C K \\
\hline $2211-29691$ & $06 / 17 / 10$ & PIPL & 199 & 603 & - X, K/W R : - LF, C K \\
\hline $2211-29690$ & $06 / 17 / 10$ & PIPL & 199 & 603 & - X, K/W G : - LF, C K \\
\hline
\end{tabular}


Table 22. Banding and marking records for least tern and piping plover chicks on the Central Platte River, 2009-10.-Continued

[Band combinations are reported by leg position (left leg top, left leg bottom : right leg top, right leg bottom), with each leg position including up to two bands. Examples: YF is yellow flag; V/W is violet over white split band. LETE, least tern; -, no band; X, metal; UNK, unknown; L= pastel blue or light blue; V, violet; I, split band; K, black; O, orange; W, white; C, cobalt blue or bright blue; G, green (kelly); R, red; Y, yellow; PIPL, piping plover; F, flag; P, pink; D, dark green (not used)]

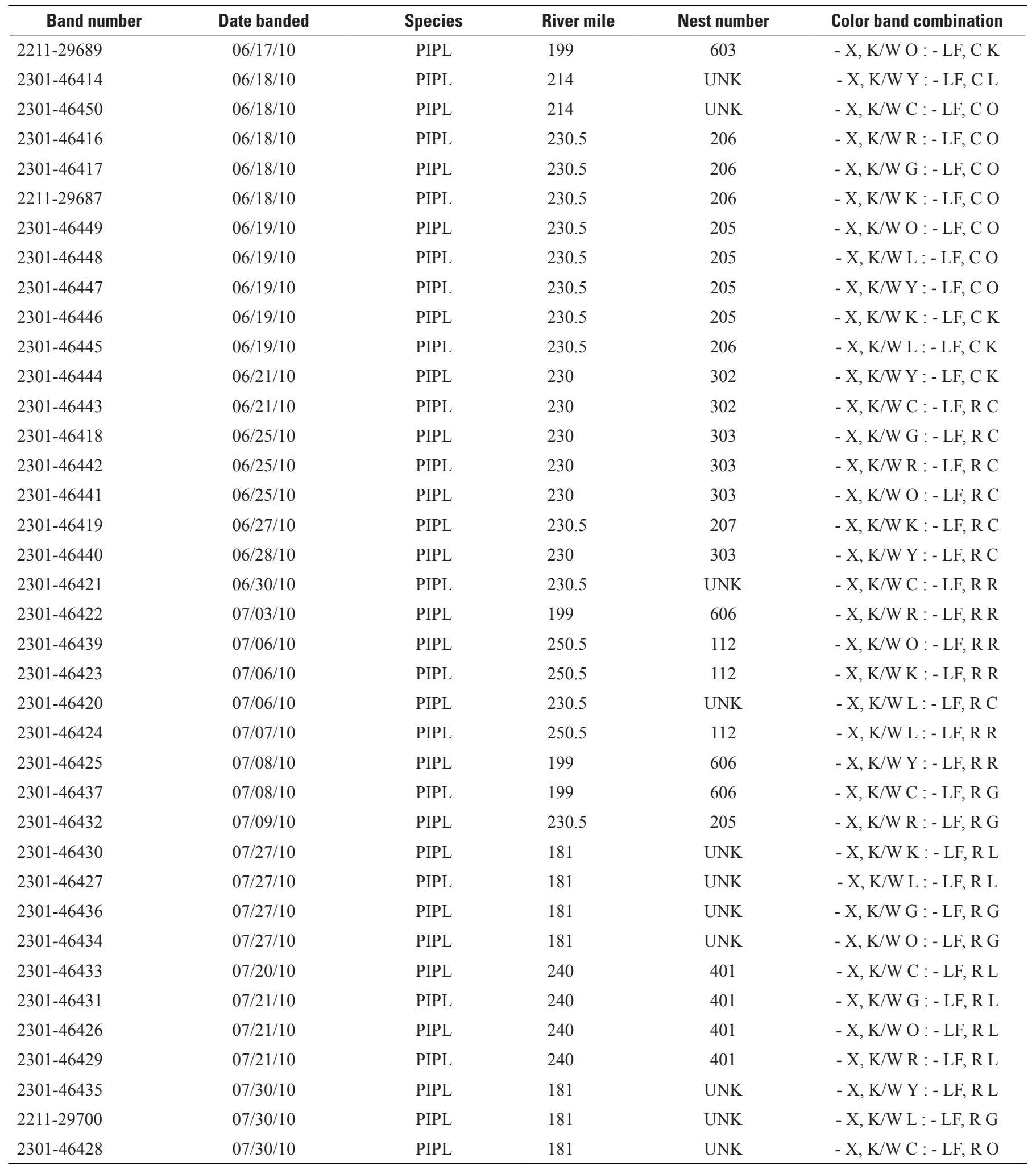





\section{Appendixes 1-4}




\section{Appendix 1. Behavior Sampling Protocol}

The goal for behavior sampling of least terns and piping plovers is to identify the (1) proportion of time spent foraging, (2) estimate the rates of foraging behaviors (plovers), (3) habitats used for foraging, and (4) success rates of foraging (terns only).

\section{Access and Timing of Behavioral Observations}

Behavioral observation sessions should occur within a 4-hour (h) interval (0600-1000, 1200-1600, and 1700-2000 h). Sessions should be allocated systematically to ensure that each location/pair is at least observed during each interval once every 2 weeks. However, if a session is missed, the next session should occur at the same time as the missed session to maintain balance in sessions among intervals.

Observers should take a path to the blind/observation location that minimizes disturbance to least terns and piping plovers. Sessions should not commence until 5 minutes (min) have passed since the observer attained position and the observer can determine presence is no longer disturbing the birds. If a plover moves out of view during focal bird sampling and the observer is able to quickly reposition to maintain observations on the bird, a 5-min no observation interval should be added after the observer has repositioned.

\section{State Behavior Categories}

State behaviors will be observed and recorded into statebehavior categories for least terns (LETE) and piping plovers (PIPL) on 5-min intervals. Scan sampling techniques will be used for least terns and focal animal sampling for piping plovers. At the beginning of the 5-min interval, observers should take 5 seconds to assess the state of each bird visible because some states may require up to 5 seconds to identify (foraging). If any foraging behaviors are observed during the bird specific 5 -second scan, code the state as foraging (even if the foraging behavior is very brief), otherwise, record the dominant behavior for the 5-second interval.

Below are lists of state behaviors (pecking, hover) grouped into the categories for data entry (foraging):

\section{Foraging:}

PIPL: pecking, gleaning (pecking food from vegetation), foot trembling (gently shakes/trembles extended foot on substrate).

LETE: hovering, plunging or diving over water (including dives that don't conclude in a plunge), consumption of food item.

2. Transport/Deliver Food (LETE only): Carrying food items (movement through the field of view when diving is not observed), delivering food items to other adults, delivering food items to chicks (delivering may occur on the ground or by dropping food items from the air).

3. Active Territorial/Parental Care: Active attendance of site or brood (fight, chase, dive directed at another animal, mobile guarding often associated with a call to chicks, broken wing display).

4. Stationary Parental Care: Parental care directed at chicks or eggs that is not associated with movement, including incubation, and brooding and shading chicks.

5. Locomotion: Any movement from one location to another (running, walking, flying), excluding Foraging and Territorial/Parental Care behaviors. For least terns, locomotion does not include any flight when carrying fish.

6. Active: Active stationary behaviors (preen, bathe, courtship, copulation). Breast-wetting of least terns should be included in Locomotion.

7. Inactive/Rest: Inactive stationary behaviors, excluding Parental Care behaviors (sleep, rest, including alert resting).

8. Out of View (PIPL only): Bird is in area, but view is obstructed and state behavior cannot be assessed.

9. Missing (PIPL only): Bird leaves observation area.

\section{Least Tern (LETE) Protocols}

Behavioral observations will be conducted at two main types of locations within a nesting colony (sandbar or sandpit) and on noncolony riverine or sandpit sites that are used by LETE. Colony nesting sites are static and include those outlined in the study plan as well as additional sites selected by the crew leader and principal investigators (PIs). Noncolony riverine or sandpit sites will be identified by traveling the river and looking for aggregations of LETE and by examining data from telemetry dataloggers located outside colonies.

LETE colony observation sessions will be up to $3 \mathrm{~h}$ long, the duration of sessions will be based on the following: (1) if there is only one pair/nest visible from a given location then sessions should be $1 \mathrm{~h}$; (2) if other pair(s) in the same colony can be observed in the same location add $1 \mathrm{~h}$ to the session for each additional pair visible (up to $3 \mathrm{~h}$ ); and (3) if other pair(s), in the same colony can be visible from different location(s), then observe up to 3 pairs/nests for 1-h sessions each.

Observers will conduct scan sampling on 5-min intervals; recording the number of adult LETE visible that are engaged in each state (see behavioral states). The interim time between each scan will be used differently depending on whether the observation is conducted at a colony site or a noncolony site.

Noncolony sites-In the interim time between each scan (3 min), select any visible-foraging adult (if more than one in 
view, randomly select with a coin, dice, or random number function on an electronic device (such as a mobile phone), if none in view continue watching until one forages in view or interval is over), and record number of all occurrence (AO) behaviors for that selected adult, ignoring $\mathrm{AO}$ behaviors by any other adults in the area. If the adult leaves the area (with or without a prey item) or stops foraging (30 seconds without an $\mathrm{AO}$ ), then reselect another foraging adult to observe; record when a new adult is selected. Conduct each subsequent observation interval the same as described above.

- LETE noncolony AO behaviors:

- Hover (hovering briefly over water)

- Plunge nonsuccess (includes dives that do not end in a plunge)

- Plunge Success (prey item visible in bill; record length class for captured prey item)

- Plunge unknown

- Eat (consumed captured prey item)

- Out of view (individual is partially hidden and AO behaviors cannot be determined)

- Carry out of area (leaves area with captured prey item in bill)

- Leave area

Colony sites-The type of observation, done in the interim time between scans, will alternate between two different types: (1) observations of forage deliveries and (2) observations of forage behavior. For example, the first interval will be devoted to observing the colony for forage deliveries by adults, the second will be used to observe foraging behavior, and the third will be used for forage deliveries by adults, and so on. If on colony sites there is no ability to observe potential foraging locations, or it is apparent that no visible foraging occurs, then only conduct forage delivery observations.

Forage Deliveries-For the 3-min interval, watch the whole colony for all forage deliveries to chicks or adults. Categorize each delivery by recipient (adult, chick, or unknown) and location of foraging (in view, out of view, or unknown).

Foraging Behavior-In the interim time between each scan (3 min), select any visible-foraging adult (if more than one in view, randomly select with a coin, dice, or PDA function, if none in view continue watching until one forages in view or interval is over), and record the colony $\mathrm{AO}$ behaviors for that selected adult. If the adult leaves the area (with or without a prey item) or stops foraging (for at least 30 seconds), then select another foraging adult to observe; record when a new adult is selected.

- LETE Colony AO foraging behaviors:

- Hover (hovering briefly over water),
- Plunge nonsuccess (includes dives that do not end in a plunge),

- Plunge success,

- Plunge unknown,

- Eat (consumed captured prey item),

- Out of view (individual is partially hidden and AO behaviors cannot be determined),

- Carry: out of area (leaves area with captured prey item in bill),

- Leaves area,

- Forage delivery to adult,

- Forage delivery to chick, and

- Forage delivery; recipient unknown.

For all foraging AO recording intervals when a foraging $\mathrm{AO}$ is recorded (hovers and plunges), also record the habitat class associated with the behavior.

- LETE foraging habitat class (predominate type within 10-20 meters [m]):

- Sandpit,

- Main channel,

- Secondary channel, and

- Braided/dendritic channel (includes shallow-water areas near tails of sandbars).

During AO observations, map all locations where foraging was observed (see below). If it is a forage sampling day then sample fish at the most recent successful foraging location observed and at two random locations (see fish sampling protocol).

\section{Piping Plover (PIPL) Protocols}

The position of each PIPL adult and accompanying brood (if applicable) will be monitored. Behavioral observations on PIPL will be focused on individual adults, pairs, or adult(s) with broods (hereafter focal unit). Thus, observations will be conducted from movable blinds that are relocated specifically to watch the targeted focal unit, regardless of location (river or sandpit). When possible use hand-held telemetry units to help locate targeted adults, so that observers can position themselves for observation in a way that minimizes disturbance.

Each session will last $1 \mathrm{~h}$ per focal unit. Three hours are allocated for behavioral sampling so that up to three focal units can be sampled per day of field work. Observers will record behavioral states and habitat classes for each individual within the focal group on 5-min intervals. Each individual (adult and chick) should be observed for 5 seconds 
to determine the dominant behavioral state (see above classes), with behaviors being linked to marked individuals if possible. If any foraging behavior (no matter how brief) is observed during the 5-second observation period, the period should be classified as foraging. Otherwise, the dominant behavior class occurring during the 5 -second period should be recorded. If the focal observation interval is classified as foraging, the location of the bird should be spot mapped.

If marks are not present or cannot be readily observed, record each individual as unknown adult or unknown chick. This type of sampling may be most easily conducted by two people, with one continually observing through a spotting scope to track individuals and verbally calling out data to the second crew member.

\section{Habitat Classes (dominant classes within the foraging area)}

\section{Landform}

1. River shoreline

2. Sandbar

3. Sandpit

\section{Moisture}

1. Dry substrate

2. Wet substrate

\section{Vegetation}

1. Bare (less than 30 percent)

2. Sparse (31-50 percent)

3. Vegetated (greater than 50 percent)

In the interim time between all focal observation intervals, the observer will record all pecks (including gleans) for a 3-min. interval on a randomly selected adult or chick (using a dice or PDA function). Record when an individual goes out of view or when that individual returns into view. Randomly select (from all visible individuals within the focal unit) a new adult or chick (alternating between adults and chicks for each peck-recording interval). If it is a forage sampling day, forage will be sampled at the most recent observed foraging location and at two random locations (see Invertebrate Sampling Protocol).

Noncolony observations of foraging piping plovers will be obtained if the opportunity is available. The data collection approach is identical to colony locations, and the data card will reflect that a noncolony site with zero known nests/ broods was sampled. Opportunities to collect these data might occur at unexpected times (such as when collecting other types of data, when floating the river, when checking telemetry stations, during noncolony tern behavior observations). These kind of data will be informative regarding the birds' choices of foraging habitat, so it would be worthwhile to spend the extra time collecting the data when opportunities arise.

\section{Active Nests/Surviving Broods}

During each session, the number of known active nests/ broods in the area will be recorded. For colony sites, this will be the number for the species within the colony, not just the number visible from a behavior data-collection location. For noncolony locations where foraging terns or plovers are observed, it is also important to record zero known active nests/broods in the area to identify these areas as off-colony foraging locations.

\section{Spot Mapping}

For piping plovers, each time a foraging state behavior is recorded, the location will be spot mapped. It will be impossible and not necessary to spot map each time foraging AOs (for example, pecks) are recorded for plovers.

For least terns, each time a plunge or dive is recorded as an $\mathrm{AO}$, an attempt will be made to spot map the location, including notation of success/fail/unknown status of the dive. However, if the number of unsuccessful dives occurring makes this cumbersome, the approach may be modified after discussion with the PIs so that spot mapping is only conducted for successful dives. 


\section{Appendix 2. Terrestrial Habitat Sampling Protocol}

Terrestrial habitat data will be collected in conjunction with piping plover forage sampling. A terrestrial habitat quadrat will be deployed at each invertebrate sampling location (including plover foraging sites and random points). Because collecting the invertebrate data can disturb the substrate because of placement of sticks and the exclosure, terrestrial habitat data will be collected before invertebrate sampling is started.

At each invertebrate sampling location, a 1-square meter $\left(\mathrm{m}^{2}\right)$ quadrat will be centered where the exclosure will be located. The following data will be recorded at this quadrat:

Land Cover: Record the dominant class within the quadrat (* indicates cover types unlikely to occur at plover foraging locations):

Dry sand-Sand substrate with no obvious moisture or vegetation,

Wet sand-Areas of moist sand with little or no vegetation,

Sparsely vegetated-Mostly sand substrate with

30-50 percent vegetation,

Mixed vegetation-Areas of greater than 50 percent vegetation with interspersed visible substrate,

Wetland-Water areas with green vegetation present,

* Submerged sand-Submerged sand substrate visible through water, and

*Open water-No substrate visible through water.

Vegetation Visual Coverage Estimates: Record the adjusted Daubenmire cover class (table 2-1) for each of the following response variables:

Total woody vegetation-Include all woody species,

Terrestrial herbaceous vegetation-Include all terrestrial species, and

Wetland herbaceous vegetation-Include all wetland species.

Stem Counts: Record the total count of all woody stems in the quadrat, counting each stem as an individual if it protrudes independently from the substrate (for example, substrate is visible between stems).

Vegetation Height: Record mean and maximum vegetation height classes as follows, including all vegetation within the quadrat: $\begin{aligned} \text { Mean height }-1= & 0-0.5 \text { meter }(\mathrm{m}), 2=0.5-1 \mathrm{~m}, 3= \\ & \text { greater than } 1 \mathrm{~m}\end{aligned}$

Maximum height $-1=0-0.5 \mathrm{~m}, 2=0.5-1 \mathrm{~m}, 3=$ greater than $1 \mathrm{~m}$
Substrate Visual Coverage Estimates: Record the Daubenmire cover class (table 2-1) for each substrate class according to its grain size:

$\begin{array}{ll}\text { Silt } & \text { less than } 0.125 \text { millimeter }(\mathrm{mm}) \\ \text { Sand } & 0.125-2 \mathrm{~mm} \\ \text { Small pebble } & 2-0 \mathrm{~mm} \\ \text { Gravel } & 10-64 \mathrm{~mm} \\ \text { Cobble } & 64-256 \mathrm{~mm} \\ \text { Boulder } & \text { greater than } 25.6 \text { centimeter }(\mathrm{cm})\end{array}$

Debris Visual Coverage Estimates: Record the Daubenmire cover class (table 2-1) for each debris type according to its size:

Terrestrial leaf litter All leaf and grass litter Wrack less than $2 \mathrm{~cm}$ stem diameter Large debris greater than $2 \mathrm{~cm}$ stem diameter; include other debris (trash)

Table 2-1. Daubenmire classification of cover (Sherfy and others, 2009).

$[>$, greater than]

\begin{tabular}{ccc}
\hline Class & $\begin{array}{c}\text { Cover range } \\
\text { (percent) }\end{array}$ & $\begin{array}{c}\text { Midpoint } \\
\text { (percent) }\end{array}$ \\
\hline 0 & 0 & 0 \\
1 & $>0-5$ & 2.5 \\
2 & $6-15$ & 10 \\
3 & $16-30$ & 23 \\
4 & $31-45$ & 38 \\
5 & $46-70$ & 58 \\
6 & $71-100$ & 85 \\
\hline
\end{tabular}




\section{Appendix 3. Fish Sampling Protocol}

The goal of fish sampling is to describe the fish abundance, species and size, and aquatic habitats where terns forage in relation to available sites. Sampling will occur on successful tern foraging locations and two random points will be selected relative to foraging location at the end of the evening behavior session (1600-2000). Forage sampling will be conducted with minnow traps on sandpit-ponds and miniMissouri River trawls on the river.

Two random points will be selected within 75 meters (m) of the forage location. The two-column random number table will be used, to modify the northing and easting ( -75 to $75 \mathrm{~m}$ ) of the Global Positioning System (GPS) point collected at the forage site. Random points will be located by navigating with the GPS. If a random point is not within the same habitat class as the forage location, the next set of numbers will be selected from the tables, and then continue until an appropriate point is selected; unsuitable points will be recorded. During river sampling, the foraging location will be sampled first, and if the sampling path (50 $\mathrm{m}$ downstream from the point) overlaps with a previous sampling path, then another random point will be selected. If river sampling points are unsafe to sample (excessive flows or depths greater than $1.5 \mathrm{~m}$ ) then new sites will be selected for random points and sampling for forage points will be discontinued.

\section{River Sampling}

The following habitat data will be collected from a sampling point: Universal Transverse Mercator (UTM), water temperature (plus or minus $[ \pm] 1$ degree Celsius $\left[{ }^{\circ} \mathrm{C}\right]$ ), turbidity $( \pm$ 1 nephelometric turbidity units [NTU]), depth $( \pm 0.1 \mathrm{~m})$, flow ( \pm 0.1 meter per second $[\mathrm{m} / \mathrm{s}]$ ), benthic substrate (predominantly: sand, clay/silt/organic, or gravel), and habitat class (main channel, secondary channel, braided/dendritic channel).

A 50-m floating line will be used to guide the direction and distance of the trawl. Anchor one end of the floating line approximately $2 \mathrm{~m}$ from the point, perpendicular to the current; a stake or weight will be used to anchor the line. The trawl will begin at the sampling point and will be towed downstream by two people spaced approximately $3 \mathrm{~m}$ apart; thus, one person is within $0.5 \mathrm{~m}$ of the floating line. The trawl needs to be towed slightly faster than the current; if the trawl-net inverts during sampling, the sample will not be counted. Net inverts or the trawl failures will be recorded and an attempt will be made again on the other side of the floating line. Once the trawl is complete, the trawl mouth will be held out of the water and the sample processed at a nearby sandbar or shoreline that is not being used by piping plovers or least terns.

All captured fish will be (1) identified to species, (2) total length measured ( \pm 1 centimeter), and (3) released as soon as possible. The net will be inverted to confirm removal of all captured fish and detritus. If too many fish are caught and they cannot be measured and identified while being pulled out of the net, then the fish will be placed in a bucket with adequate water to reduce chance of mortality. Fish identification guides and taxonomic keys used on the Missouri River are available to assist in identification.

\section{Sandpit Pond Sampling}

A canoe will be used to navigate to sampling points on sandpit ponds. On windy days, it may be necessary to anchor the canoe to maintain location; if so, the anchor will be deployed as far upwind as possible and the anchor line will be scoped out until the point is reached. Once at a sampling point, the following habitat data will be collected: UTM, water temperature $\left( \pm 1^{\circ} \mathrm{C}\right)$, turbidity $( \pm 1 \mathrm{NTU})$, depth $( \pm 0.25 \mathrm{~m}$; increment minnow traps and anchor lines for minnow traps accordingly), benthic substrate (sand, silt/clay/organic, gravel, or greater than $0.75 \mathrm{~m}$ deep).

Minnow traps will be deployed by driving the stake ends into the substrate and point lead to the center of the pond, if depth is less than $0.75 \mathrm{~m}$, or floated at the surface for points with depths greater than $0.75 \mathrm{~m}$. Ensure that minnow traps are anchored in place after they are floated, and that the line length is only slightly longer than the depth to prevent the trap from moving if the wind direction changes. The time the trap was deployed will be recorded ( \pm 1 minute). The traps will be left in place for 24 hours, retrieved, collection time recorded $( \pm 1$ minute), and samples processed as described above.

\section{Sampling Equipment}

1. Fish Kit

- Fish identification binders,

- Aquatic habitat description key,

- Fish sampling data cards,

- 2-m pole,

- 50-m float cord (throw ropes),

- Turbidity meter,

- Flow meter,

- Fish sampling pans plus grid laminate sheetsrulers,

- Headband- magnifying loup,

- Thermometer,

- Paper cups,

- Preservative and jars,

- Bucket,

- Camera,

- Index cards, and

- GPS. 
2. Missouri trawl - clean and mended.

3. Three minnow traps, lines, and anchors (incremented with $1-\mathrm{m}$ and 25-m hash marks). 


\section{Appendix 4. Invertebrate Sampling Protocol}

The goal of invertebrate sampling is to describe the invertebrate taxa, abundance, and terrestrial habitats where piping plovers forage in relation to available sites. Invertebrate sampling will be conducted using four paint stir sticks coated with Tanglefoot (The Tanglefoot Company, Grand Rapids, Michigan) insect trap with two placed horizontally and two placed vertically within a 1 -square meter exclosure (hereafter, sticky sticks). Sampling will occur at both brood-specific-foraging locations and two random points selected relative to foraging location at the end of each 1-hour (h) behavior session, if foraging was observed (see Behavior Protocol). Invertebrate sampling will occur only (1) after behavioral observations during the morning interval $(0600-1000 \mathrm{~h})$, and (2) when there is minimal chance of rain and wind speeds are expected to be below 30 kilometers per hour (18 miles per hour) during the sampling period.

Two random points will be selected within 75 meters (m) of the forage location; the random points must be the same habitat class (for example, landform, moisture, and vegetation [appendix 2]) as those of the foraging location. The two-column random number table will be used to modify the northing and easting ( -75 to $75 \mathrm{~m}$ ) of the GPS point collected at the forage site. For example, if the UTM of the foraging site is 493,962 by $4,500,757$, and the random numbers from the table are +18 and -17 , then the random point is at UTM 493,980 by $4,500,740$. Random points will be located by navigating with the GPS. If a random point is not within the same habitat class as those of the forage location then the next set of numbers will be selected from the tables; continue until two appropriate points are selected; and record number of unsuitable points. If a foraging location is within a narrow linear habitat class, random point selection will be constrained to the same habitat class using the change of easting as the distance from the forage sampling location (positive number move norht or east; negative number move south or west). If the random point is within $100 \mathrm{~m}$ of an active least tern or piping plover nest or brood, choose another location.

Habitat characteristics will be taken at each sample site prior to collection, following the Riverine Habitat Protocol.

Small exclosures must be used around sticky sticks to keep piping plovers and other birds from being entangled during sampling. The exclosures will be made of $0.25-\mathrm{m}$ tall 1 -square centimeter $\left(\mathrm{cm}^{2}\right)$ nylon mesh netting held up in the corners by four wooden stakes. The traps consist of four sticky sticks (paint stir-sticks thinly covered with 20 centimeters (cm) of Tanglefoot ${ }^{\circledR}$ insect trap). Two sticks will be covered on one side of the nonhandle end (horizontal stick) and the other sticks will be covered on both sides (vertical stick). The vertical sticks will be driven handle first into the ground (with a wide side facing into the wind) so that the start of the Tanglefoot is even with the surface of the substrate. The horizontal sticks will be placed flat on the substrate (sticky side up),
$10 \mathrm{~cm}$ away from the vertical stick (perpendicular to the direction of the wind). The handle of the sticks will be labeled with study area, site, brood/nest number, point type (for example, forage or random), stick number ( $\mathrm{H} 1, \mathrm{~V} 1, \mathrm{H} 2, \mathrm{~V} 2)$, date, and time set. The study area, site, brood/nest number, point type, date, time set, habitat class, and weather will be recorded on the forage sampling data sheet.

Movements in the immediate area should be avoided to prevent invertebrates or sand being driven into traps. The traps will be retrieved after 2-3 hours; the end time will be recorded on the forage sampling data sheet. Invertebrates on retrieved sticks will be identified and counted immediately outside the study area. Invertebrates less than 3 millimeters ( $\mathrm{mm}$ ) should be counted but not identified. Invertebrates $3 \mathrm{~mm}$ or greater will be counted and identified to order (all) and to family in order Diptera. If unknown invertebrates are encountered, reference materials will be consulted for identification; if identification is still unresolved (1) preserve a voucher specimen in ethanol, (2) name and label it (for example, "unknown A"), and (3) make sure all references in data use the same name, especially if the unknown taxon occurs in another sample. When invertebrates cannot be counted and identified on the same day the sample is collected, sticky sticks will be frozen for later identification.

Sampling will include up to 10 minutes of disturbance to chicks and adult plovers during setup of the exclosure, sticky sticks, and substrate sampling, a $2-3 \mathrm{~h}$ passive sampling period when investigators are outside the area, and another period up to 10 minutes of potential disturbance to remove the exclosure and sticky sticks.

\section{Equipment list:}

- Paint stir sticks,

- Tanglefoot,

- Putty knife,

- At least three exclosures,

- Hammer,

- GPS, and

- Datasheets. 
Publishing support provided by:

Rolla and Lafayette Publishing Service Center

For more information concerning this publication, contact: Director, USGS Northern Prairie Wildlife Research Center 8711 37th Street Southeast

Jamestown, North Dakota 58401

(701) 253-5553

Or visit the Northern Prairie Wildlife Research Center Web site at: http://npwrc.usgs.gov/ 


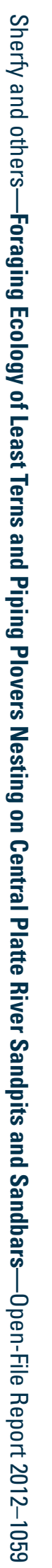

